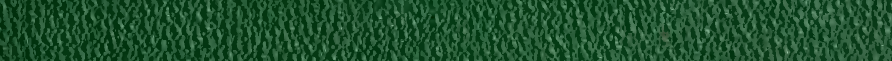

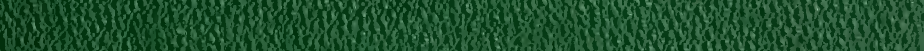
3.5.

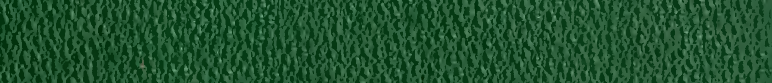

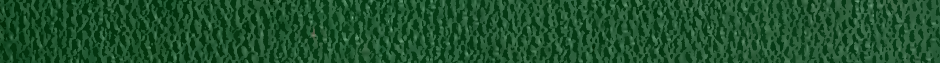

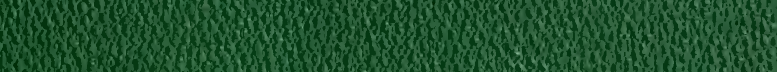

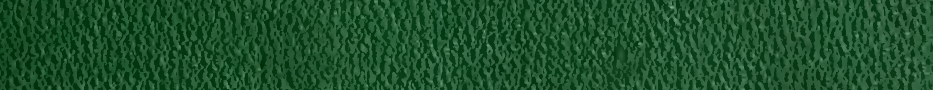

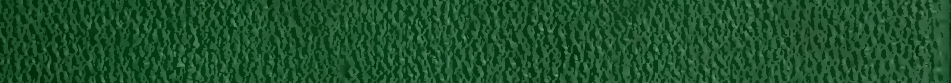

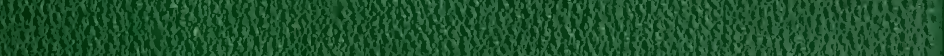
W. H.

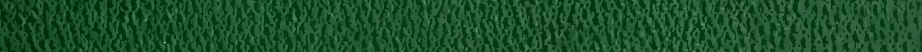

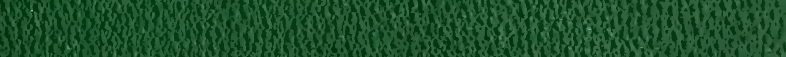

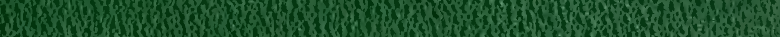

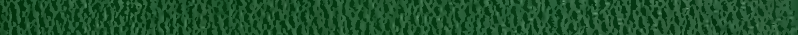
30

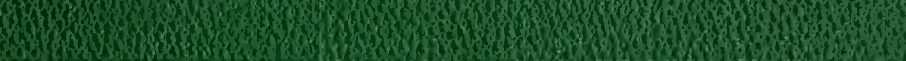

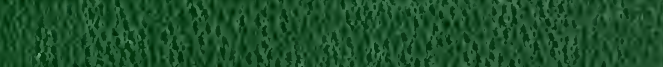

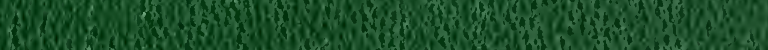
(x)

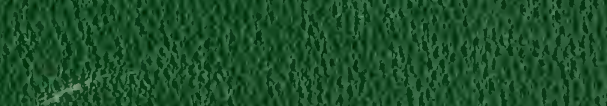

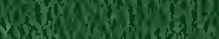




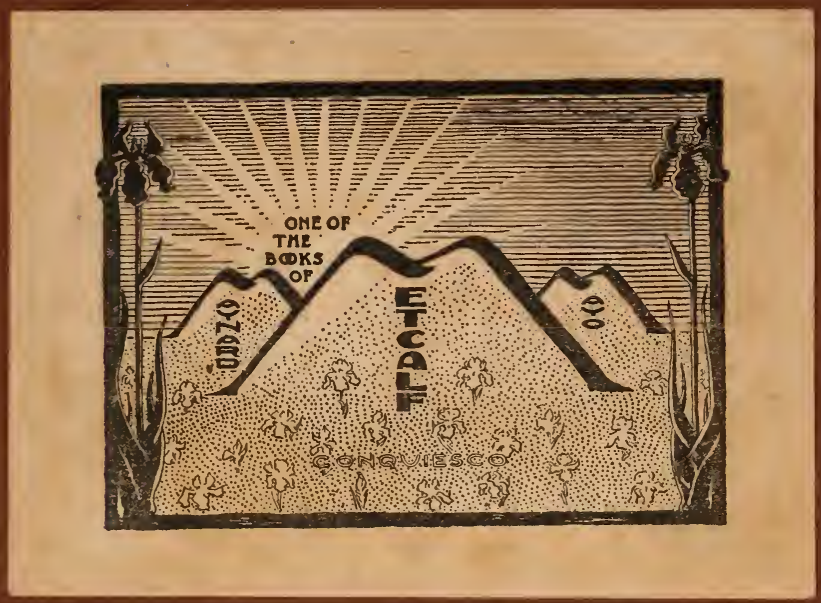




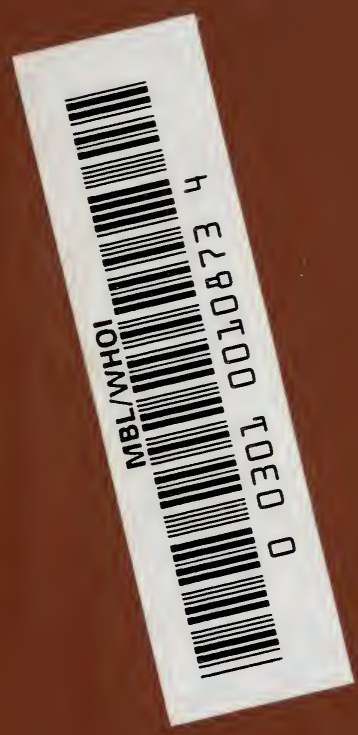



In the Press, in Tie Volumes, Crown 8vo., with mumerous Illustrations,

\section{THE BEGINNINGS OF LIFE.}

BY

THE SAME A U THOR.

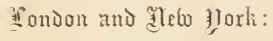

M A C M. I L L A N A N D C O. 



\section{LOWEST ORGANISMS.}

Fig. I.

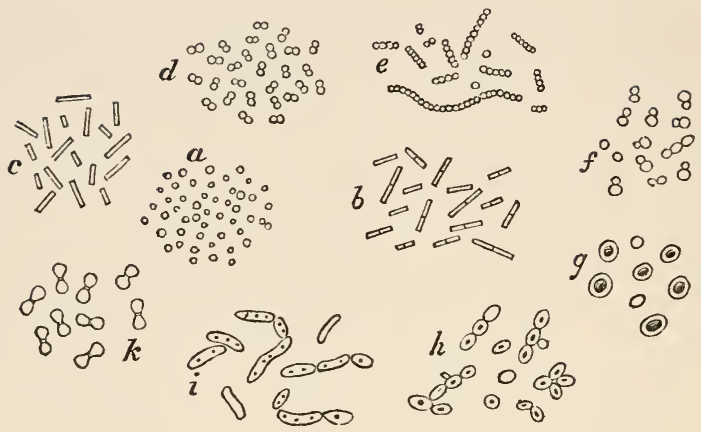

Fig. 2.

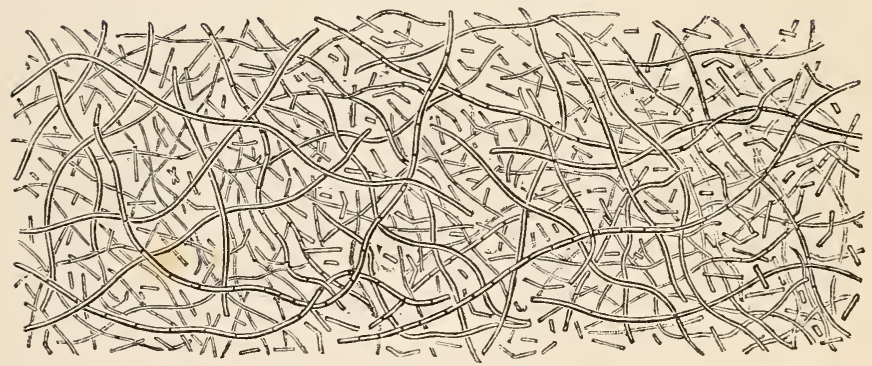

Fig. 1.-The simplest forms of Life-Bacteria, Torula, \&.c.

Fig. 2.-Bacteria, Vibriones, and Leptothrix filaments.

( $\times 800$ diameters.) 


\title{
THE MODES OF ORIGIN
}

OF

\section{LOWEST ORGANISMS:}

INCLUDING

\begin{abstract}
A DISCUSSION OF THE EXPERIMENTS
OF M. PASTEUR,
\end{abstract}

AND A REPLY TO SOME STATEMENTS BY PROFESSORS HUXLEY AND TYNDALL.

By H. CHARLTON BASTIAN, M.A., M.D., F.R.S.,

FELLOW OF THB ROYAL COLLEGE OF PHYSICIANS;

PROFESSOR OF PATHOLOGICAL ANATOMY IN UNIVERSITY COLLEGE, LONDON ;

ASSISTANT PHYSICIAN TO UNIVERSITY COLLEGE HOSPITAL, AND TO THE NATIONAL HOSPITAL FOR THE EPILEPTIC AND PARALYSED.

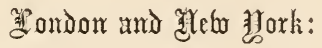

M A C M L L A N A N D CO.

I $87 \mathrm{r}$. 
"Qvant à ce qui concerne la prétendue incubation d'œufs d'Infusoires dans l'infusion, il faudrait d'abord prouver l'existence de ces œufs. Les dit on trop petits pour être aperçus, c'est avouer qu'on ne peut rien savoir de leur existence. * * * Croire que partout où l'on rencontre des Infusoires, ils ont été précédés d'œufs, c'est donc admettre une pure hypothèse, qui n'a d'autre fondement que l'analogie. * * Si c'est seulement par l'analogie qu'on suppose des œufs chez eux, il faut accorder à ces œufs des propriétés semblables à celles de tous les œufs connus ; car ce serait jouer sur les mots que de supposer qu'ils en ont de particulières à eux seuls." - Burdach's Traité de Physiologie, Translation by Jourdan, 1837, t. i., . 22. 


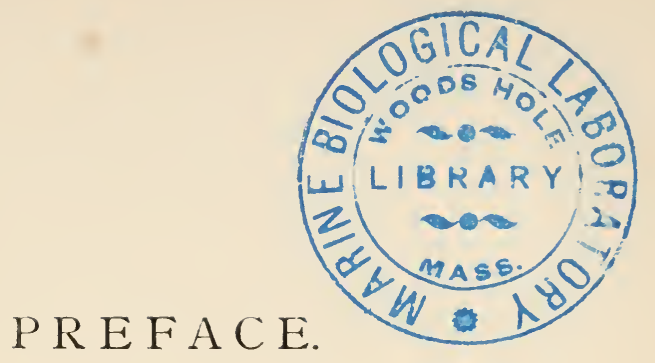

यद्यक्क

HAVING been compelled by the results of my investigations on the question of the Origin of Life to arrive at conclusions adverse to generally received opinions, I found that several persons having high authority in matters of science, were little disposed to assent to these views. To a great extent this seemed due to the fact that a distinguished chemist had previously gone over some of the same ground, and had arrived at precisely opposite conclusions. M. Pasteur has been long known as an able and brilliant experimenter, and some of his admirers seem to regard him as an almost equally faultless reasoner.

Renewed and prolonged experimentation having tended to demonstrate the truth of my original conclusions, and to convince me of the utter untenability of M. Pasteur's views, it seemed that the best course to pursue would be, at first, to endeavour to show into what errors of reasoning 
M. Pasteur had fallen, and also how his conclusions were capable of being reversed by the employment of different experimental materials, and different experimental methods. Then, having presented, in a connected form, evidence which might suffice to shake the faith of all who preserved a right of independent judgment, one might hope to have paved the way for the reception of new views-even though they were adverse to those of M. Pasteur. The present volume contains, indeed, only a fragment of the evidence which will be embodied in a much larger worknow almost completed - relating to the nature and origin of living matter, and in favour of what is termed the physical doctrine of Life.

The question of the mode of origin of Living Matter, is inextricably mixed up with another problem as to the cause of fermentation and putrefaction. M. Pasteur's labours were, at first, undertaken in order to solve the latter difficulty - to decide, in fact, between two rival hypotheses. It was held, on the one hand, that many ferments were mere dead nitrogenous substances, and that fermentation was a purely chemical process, for the initiation of which the action of living organisms was not necessary; whilst, on the other hand, 
it was also maintained that no fermentation could be initiated without the agency of living thingsin fact, that all ferments were living organisms. The former may be called the physical theory of fermentation, of which Baron Liebig is the most prominent modern exponent; whilst the latter may be termed the vital theory of fermentation, and this is the doctrine of M. Pasteur. All the facts which I have to adduce, so far as the subject of fermentation is concerned, are wholly in favour of the views of Baron Liebig.

And, the conclusions arrived at in this work are confirmed by the results of several unpublished experiments, in which living organisms have been taken from flasks that had, a few weeks before, been hermetically sealed and heated for a variable time to temperatures ranging from $260^{\circ} \mathrm{F}$. to $302^{\circ} \mathrm{F}$.

With the view of aiding some of my readers in their interpretation of the results of some of the experiments contained in this volume, I would call their attention to the following considerations. If fluids in vacuo (in hermetically-sealed flasks), which were clear at first, have gradually become turbid; and if on microscopical examination this turbidity is found to be almost wholly due to the presence of Bacteria or other organisms, then it 
would be sheer trifling gravely to discuss whether the organisms were living or dead, on the strength of the mere activity or languor of the movements which they may be seen to display. Can dead organisms multiply in a closed flask to such an extent as to make an originally clear fluid become quite turbid in the course of two or three days?

And if any one wishes to convince himself as to whether such turbidity can occur in a flask which is still hermetically sealed, let him take one that has been prepared in the manner I have elsewhere described, carefully heat the neck of it in a spirit-lamp flame, and see how the rapid in-bending of the redhot glass testifies to the preservation of a partial vacuum within. The vacuum in such cases is only partially preserved, because of the emission of a certain amount of gases within the flask-such as invariably occurs during the progress of fermentation or putrefaction.

In these experiments with heated fluids in closed flasks, nothing is easier than to obtain negative results. The same kinds of infusions which-if care has been taken to obtain them strong enoughwill in a few days teem with living organisms, often show no trace of living things after much longer periods, when the solutions are weak. Again, in 
those cases where only a few organisms exist in a solution which has been made the subject of experimentation, nothing is easier than by a perfunctory examination of the fluid to fail in finding any of these sparsely-distributed living organisms. Experiments, the results of which are positive, may, therefore, in the absence of sufficient care, be cited as negative; and experiments which would otherwise have been crowned with unmistakeably positive results, may be rendered wholly barren by the employment of infusions which have been carelessly made.

A word of explanation seems necessary with regard to the introduction of the new term Archebiosis. I had originally, in unpublished writings, adopted the word Biogencsis to express the same meaning-viz, life-origination or commencement. But in the mean time the word Biogencsis has been made use of, quite independently, by a distinguished biologist, who wished to make it bear a totally different meaning. He also introduced the word Abiogenesis. I have been informed, however, on the best authority, that neither of these words can-with any regard to the language from which they are derived-be supposed to bear the meanings which have of late been publicly assigned 
to them. Wishing to avoid all needless confusion,

I therefore renounced the use of the word Biogenesis, and being, for the reason just given, unable to adopt the other term, I was compelled to introduce a new word, in order to designate the process by which living matter is supposed to come into being, independently of pre-existing living matter.

\section{H. Charlton Bastian.}

Queen Anne Street, $W$, May 8, 1871 . 


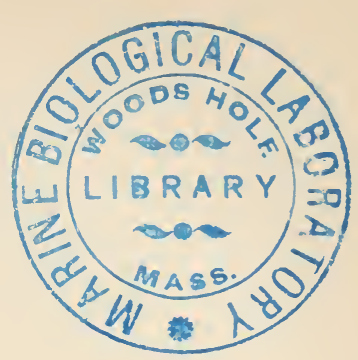

THE MODES OF ORIGIN

OF

\section{O WEST O R G A N I M S.}

THE mode of origin of Bactcria, and, to a less extent, of Torula, has been much discussed of late, and many different views have been advocated on this subject by successive writers.

It is of much importance to bear in mind when such views are under consideration, that a short time since nothing was positively known concerning the lifehistory of these organisms. However strongly, therefore, certain persons are inclined to rely upon the analogy which is supposed to obtain between these doubtful cases, and the multitudes of known cases -in which it can be shown that organisms are the offspring of pre-existing organisms-it must always be borne in mind that in many of the doubtful cases, where the simplest organisms are concerned, there is also an analogical argument of almost equal weight adducible in favour of their de novo origination after a fashion, and under the influence of laws 
similar to those by which crystals arise. To rely too exclusively upon an argument from analogy is always perilous: it is more than usually so, however, in a case like this, where what is practically an opposing analogy may be deemed to speak just as authoritatively in an opposite direction.

There is one consideration, moreover, which deserves to be pointed out here, and which does not seem to have occurred to most of those who so firmly pin their faith to the truth of the motto "omne vivum ex vivo." The every-day cxperience of mankind, supplemented by the ordinary observations of skilled naturalists, does pretty fairly entitle us to arrive at a wide generalization, to the effect that some representatives of every kind of organism are capable of reproducing similar organisms. But, whilst this is all that the actual every-day experience of mankind warrants being said, and whilst there is in reality the widest possible gulf between such a generalization and that which is expressed by the motto "omne vivum ex vivo," the latter formula has of late been spoken of as though it were the one which was in accordance with the daily experience of mankind, rather than the other, which gives expression to a generalization of a much narrower description. This experience, in reality, affords no evidence which could entitle us to place implicit belief in the formula "omne vivum ex vivo."

Whilst we do know something about the ability which most organisms possess of reproducing similar 
organisms, we cannot possibly say, from direct observation, that every organism which exists has had a similar mode of origin, because the cases in which organisms may have originated de novo are the very cases in which their mode of origin must elude our actual observation. Such a statement, too, would be all the more dangerous, in the face of the other analogy, when it can actually be shown that some organisms do make their appearance in fluids after precisely the same fashion as crystals.

Although, therefore, there is a contradiction between the unwarrantable and ill-begotten formula, "omne vivum ex vivo," and the doctrines of what has been called "Spontaneous Generation"; there is no contradiction whatever between such doctrines and the only generalization which we are really warranted in arriving at, to the effect that some representatives of every kind of organism are capable of reproducing similar organisms.

Bacteria, Tonula, or other living things which may have been evolved de novo, when so evolved, multiply and reproduce just as freely as organisms that have been derived from parents.

The views as to the origin of Bacteria and Torule which are most worthy of attention, may be thus enumerated:-

a. That they are independent organisms derived by fission or gemmation from pre-existing Bacteria and Tcrula. 
b. That they represent subordinate stages in the life-history of other organisms (fungi), from some portion of which they have derived their origin, and into which they again tend to develop.

c. That they may have a heterogeneous mode of origin, owing to the more complete individualization of minute particles of living matter entering into the composition of higher organisms, both animal and vegetal.

d. That they may arise de novo in certain fluids containing organic matter, independently of preexisting living things (Archebiosis).

I shall make some remarks concerning each of these views, though the evidence I have to adduce mainly concerns the possibility of the origin of Bacteria and Torula in the way last alluded to, viz., by Archcbiosis.

The third mode of origin is what is called $\mathrm{Hc}$ terogencsis; whilst the first and second modes are the representatives of more familiar processes, included under the head of Homogenesis. Thus, in accordance with the first view, Bacteria may be regarded as low organisms having a distinct individuality of their own and multiplying by a process of fission-thus affording instances of what I propose to term direct Homogenesis. Whilst, in accordance with the second view, Bactcria are supposed to represent merely one stage in the life-history of higher organisms, which are therefore reproduced by an indirect or cyclical process of Homogenesis. 
The possible modes of origin of Bacteria and Torulce may, therefore, be tabulated as follows :-

Modes of origin $\left\{\right.$ I. Homogenesis. $\left\{\begin{array}{l}a \text {. Direct. } \\ b .\end{array}\right.$ of Bacteria and
Torulce.

3. Archebiosis.

i. Holiogenetic Mode of Origin of Bacteria AND TORULA.

Bacteria and Torula being already in existence, they may, undoubtedly, reproduce organisms similar to themselves by processes of fission and gemmation - in the same way that other low protistic organisms propagate their kind. Although so many reasons rendered this view probable, it was some time before I was able actually to confirm it by personal observations in the case of Bactcria. In the ordinary microscopical examination of portions of an infusion containing these organisms, an observer may watch for hours and never see a single instance of such fission occurring. His attention is apt to be distracted by the number of organisms which are constantly flitting before his view, and he is, moreover, perhaps apt to pay particular attention to those which seem by their movements to be most obviously alive.

I have observed the process most plainly when a few Bacteria have been enclosed in a single drop of fluid, pressed into a very thin stratum, in a "live-box" kept at a temperature of about $90^{\circ}$ Fahr. by resting 
on one of Stricker's warm-water chambers placed on the stage of the microscope. Under these conditions, I have seen a Bacterium of moderate size divide into two, and each of these into two others somewhat smaller, in the course of fifteen minutes.

It is still more worthy of remark, that in all cases (so far as I have been able to observe), this, the most certain sign of vitality which such organisms are capable of manifesting, is shown by those which, from their stillness, might be considered dead. The Bacteria which are about to divide are generally either motionless, * or merely present slight oscillating movements. The separation is quickly brought about at the joint, so that the original organism divides into two equal portions; and these, lying close together, soon develop a new construction as they grow, through which a further division may occur.

That the Bacteria which reproduce should be in a comparatively quiescent condition, seems not difficult to understand. Such rudimentary organisms do not appear to possess cilia or other locomotory appendages : their movements are, therefore, in all probability dependent upon the mere molecular changes which are taking place within them, and upon which their life and nutrition depend. The process of fission must, however, be considered as the result of a new effort at

* Those which are quite motionless are always in close apposition either with the under surface of the covering glass, or with the surface of the glass on which they are situated. 
equilibrium, which has, perhaps, been necessitated by molecular changes that have occurred during a preceding period of growth. The living matter which is no longer able to exist round a single centre, re-arranges itself around two centres, - as a result of which, fission occurs. It seems only natural, therefore, that whilst this active work of molecular rearrangement is going on, those other molecular movements which occasion the actual locomotion of the organism from place to place, should be more or less interfered with.

This is the one and only mode of multiplication of Bacteria and of Torule which is actually known to occur; and such a limitation is in accordance with the more general fact, that processes of fission or gemmation are the only means of reproduction that are known to occur in the lower kinds of organisms, belonging to the PROTISTIC kingdom.

However well this process of fission may have been established, as a frequent mode of reproduction of Bacteria, such a fact does not lend any support to the notion that these are necessarily distinct and independent organisms. Torula (of which beer-yeast is the most familiar example) may similarly undergo this process of mere vegetative repetition to an indefinite extent, whilst only some of the products develop into fungi. The gonidia of lichens may also reproduce indefinitely in this fashion, and only some of the products of multiplication may go on to the 
production of lichens similar to that from which the gonidia had been derived.

It is a fact, however, admitted by many, and which any patient microscopist is capable of verifying for himself, that some Bacteria do develop into Leptothrix filaments, and that these are capable of passing into a dissepimented mycelial structure of larger size and undoubtedly fungus nature-from which fructification of various kinds may be produced. Some Bacteria may therefore develop into some fungi, just as certainly as some Tonula may develop into other fungi, or, just as surely as some multiplying gonidia may develop into lichens.

In order to prove, however, that the Bacteria which happen to go through this development into Leptothrix and thence into fungi, are strictly to be considered as necessary links in the life-history of fungi, it would be essential for the person holding such views, to show that Bacteria could not arise independently-or at least that no independently evolved Bacteria could develop through Leptothixforms into a fungus. And, similarly, for the other kinds of organisms: in order to establish that the Torula cell is a necessary link in the life-history of certain fungi, or the gonidial cell a necessary link in the life-history of lichens, it would be necessary to show that Torule or gonidial cells could not originate te nowo-that no independently evolved Torula or gof i ial cell could develop into a fungus or a lichen. 
An easier position to establish would be, that the Bactcrium or the Torula were occasionally links in the life-history of fungi, or that the gonidial cell was an occasional link in the life-history of a lichen. This doctrine would leave the other more difficult problems, - as to the possible existence of supplementary modes of origin for such organisms by Heterogenesis or by Archebiosis-perfectly open questions.

To establish the position that Bacteria are occasional links in the life-history of fungi, it would be only necessary to show that some of the Bactcria which develop into fungi through Leptothrix have derived their origin from pre-existing fungi. This is the view which Hallier* has endeavoured to establish ; it is also the doctrine of M. Polotebnow, $\dagger$ and one, moreover, to which Professor Huxley $\ddagger$ inclines. Even this mode of origin for Bacteria, however, has not been so decisively established as might be desired. IVith regard to Torulce, we do possess sufficient evidence tending to show that some of them may arise from pre-existing fungi, and we are equally certain that some gonidial cells are thrown off from lichens. The analogical evidence is, therefore, in favour of the view that minute particles which are budded off from the mycelium of certain fungi, may subsequently lead an

* Phytopathologie, I867. Hallier seems, however, strongly inclined to disbelieve in the origin of these organisms by Heterogenesis or by Archebiosis.

$\dagger$ Sitzungsber. der K. Akad. zu Wien, I870, Band lx:, Heft iv. $\ddagger$ Quarterly Journal of Microscopical Science, Oct., I870, 
independent existence, and multiply in the form of Bacteria-although many of the cases in which such buds seem to be given off, may be merely cases in which co-existing Bacteria have become adherent to fungus filaments or to Torulce*

But, with reference to these supposed cases of budding, and also to those others in which the contents of a spore or sporangium break up into what Professor Hallier calls "micrococci" (which are generally incipient Bacteria), it would be difficult for us to decide whether such processes are normal or abnormal. When we have to do with such organisms, in fact, there may be the nicest transitions between what is called Homogenesis, and what, when occurring in other organisms, we term Heterogenesis. It may be that the production of such "micrococci" from the spore or sporangium of the fungus is not an invariable incident in the life-history of the species, but rather an occasional result of the influence of unusual conditions, or of failing vigour on the part of the organism. In this latter case we should have to do with a process of

* Notwithstanding what Professor Huxley has said, I believe it to be almost certain that in many cases Bacteria exist in a solution in which there are neither Torulce nor developed fungi. And, on the other hand, I have seen fungi growing in a simple (boiled) solution of tartrate of ammonia, for weeks together, without the appearance of Bacteria or the occurrence of any turbidity of the solution; and on two or three occasions I have seen Torula swarming in an infusion without the presence of Bacteria. 
Heterogenesis; although, as I have just stated, in respect to such low and changeable organisms, scarcely any distinct line of demarcation can be drawn between Homogenesis and Heterogenesis.

The evidence seems, therefore, against the notion that Bacteria or Tonula are ordinary, independent living things, which merely reproduce their like.

That some Bacteria are produced from pre-existing Bacteria, just as some Torula are derived from preexisting Torula, may, it is true, be considered as settled. But, so far as we have yet considered the subject, there may be just as good evidence to show that Bactcria and Torule are capable of arising de now', as there is that some of them are capable of developing into fungi.

If this were the case, such types could only be regarded as the most common forms assumed by new-born specks of living matter; and, by reason of their origin--which would entail an absence of all hereditary predisposition-they might be supposed to be capable of assuming higher developmental forms.

Now, as a matter of fact, worthy of arresting our attention, we do find that some Bacteria are capable of growing into Leptothrix, whilst this is able to develop continuously into a fungus; just as we also know that some Torulce are capable of growing into other fungi.

Should it be established, therefore, that Bactcria and Torule are capable of arising de novo, the facts 
concerning their mutability are harmonious enough with theoretical indications.

But, as I have before indicated, although it is quite true that some Bacteria develop into fungi, such forms may constitute no necessary links in the life-history of other fungi. I have suggested that in those (occasional) cases in which they do occur as links in the lifehistory of fungi, there is room for doubt whether these Bacteria are to be considered as normal products, or as abnormal results (heterogeneous offcasts), brought about by some unusual conditions acting upon the parent fungus. That is to say, we may be doubtful whether in such a case their origin ought to be considered Homogenetic or Heterogenetic. It may be that many of the lower fungi are such changeable organisms, and so prone to respond to the various "conditions" acting upon them (which would be almost certainly the case if they had been developed from a Bacterium in two or three days-the Bacterium itself having been evolved de novo) that no very valid distinction can here be drawn between Homogenesis and Heterogenesis. Our whole point of view, in fact, concerning such fungi as are seen to develop through Leptothrix forms from Bacteria must be entirely altered, if it is once conceded that Bacteria may arise de novo. Such simple Mucedinece would then have to be regarded as mere upstart organisms only a few removes from dead matter, and - in view of the greater molecular mobility of living matter-capable of being 
modified in shape and form even more than the most changeable crystals under the influence of altering "conditions." We should have no longer to do with the members of a stable species, which had been reproducing its like through countless geologic ages anterior to the advent of man upon the earth. Indeed, in order to reconcile such a possibility with the seemingly contradictory fact of the known extreme changeability of these lower forms of life, we hear only vague hints thrown out about our imperfect knowledge of the "limits within which species may vary." As if, in the face of what we do know concerning hereditary transmission, this changeability did not make it almost impossible to conceive that there should have been an unbroken series of such organisms since that remote epoch of the earth's history, when the first organisms of the kind made their appearance. It does not seem to me that the presumed permanence of a very changeable organism is consistent with, or rendered more explicable by, the supposition that some representatives of the species have constantly been undergoing progressive modifications which have been successively perpetuated by inheritance, in the shape of distinct specific forms. Why should some be presumed to have undergone so much change, whilst others (presenting an equal and an extreme degree of modifiability, even to the present day) are supposed to have preserved the same specific form through a countless series of changing influences? 
2. Heterogenetic Mode of Origin of Bacteria AND OF TORULA.

It has been long known that Bacteria and Torule are frequently to be found within vegetable cells, taken even from the central parts of plants, whenever these are in a sickly condition or are actually dying. They are apt to exist also within epithelial cells taken from the inside of the mouth; and the frequency and abundance with which such organisms are met with in these cells, is almost in direct proportion to the malnutrition and lack of vital power in the individual who is the subject of observation. Then, again, in persons who have died of adynamic diseases, in the course of twenty-four or thirty-six hours (during warm weather) Bacteria may be found in abundance within the bloodvessels of the brain and of other parts, although no such Bacteria were recognizable in the blood of the individual during life.

In these cases we must, in order to account for the presence of the Bacteria and Torula, either suppose that such organisms, in an embryonic state, are almost universally disseminated throughout the various textures of higher organisms, both animal and vegetal (though they are only able to develop and manifest themselves when the higher organisms, or the parts of them in which the Bacteria or Torula are met with, are on the eve of death), or else we must imagine that when the vital activity of any organism, whether 
simple or complex, is on the wane, its constituent particles (being still portions of living matter) are capable of individualizing themselves, and of growing into the low organisms in question. Just as the life of one of the cells of a higher organism may continue for some time after the death of the organism itself, so, in accordance with this latter view, may one of the particles of such a cell be supposed to continue to live after even cell-life is impossible.

Now, to many persons, the latter seems to be a much simpler hypothesis than the former, and one, moreover, which is more in accordance with known facts. People's views, however, on this subject are likely to be much influenced by their notions as to the possibility of Bacteria arising by a process of Archebiosis. Although some may be inclined to accept the doctrine of Heterogenesis, the same persons, being "vitalists," may not readily believe in the doctrine of Archebiosis, because this implies the vivification of dead matter-the conversion of notliving elements into a living combination. Those, however, who do believe in Archebiosis will-if the necessary evidence be forthcoming-all the more readily yield their assent to the doctrine of Heterogenesis, because it is a much less novel thing to have to believe in the mere transformation of living matter, than in the possibility of its origin de $n 0 v 0$.

Evidence of a tolerably satisfactory nature, how- 
ever, is forthcoming, which may speak independently in favour of the doctrine of Hetcrogenesis.

It has been affirmed by Crivelli and Maggi* that they have actually seen the particles within granular epithelial cells (taken from the back of the tongue of a patient suffering from diabetes) grow and elongate, so as to give rise to Bacteria, or fuse in longitudinal series, so as to form a Vibrio. $\dagger$ And, moreover, as I have myself ascertained, if one takes healthylooking epithelial scales scraped from the inside of the mouth, which appear to contain nothing but the finest granules, and places them with a little saliva in a "live-box" (and this within a damp chamber liept at a temperature of about $90^{\circ}$ Fahr.), in the course of from 5 to ro hours, the cells may be found to be studded throughout with motionless Bacteria. Of course it may be said that the granules originally seen in the cells were offcasts from pre-existing Bactcria $\ddagger$ which had gained access to the cell.

* Rendiconti del R. Istit. Lombardo, Ser. II. Vol. I, p. I I.

$\uparrow$ However novel such a mode of origin of independent Bacteria and Vibriones may appear to some, it will seem much less strange and unlikely to others who have seen, as I have done, an Amceba, or an Actinophrys-like body, originate from the progressive molecular modifications taking place in a mass of chlorophyll and protoplasm within the filament of an alga. Many independent observers have watched all the stages of this process, and some have even seen Ciliated Infusoria originate by such a metamorphic change.

$\ddagger$ Or offcasts from pre-existing fungi,- constituting the "micrococci" of Professor Hallier. 
And although, to many, this may seem an extremely improbable supposition, it is, nevertheless, one which it. would be very difficult to disprove. The improbability of the notion is increased, moreover, when we find that Bacteria, and even Tomula, will develop just as freely within closed cells taken from the very centre of a vegetable tuber, as they will in the midst of the more solid epithelial cell from the inside of the mouth. If it be urged that in this latter situation, there is the greatest chance of the cells being brought into contact with Bacteria, and that it must be considered possible for imaginary minute offcasts from these Bacteria to make their own way into the substance of the epithelial cell, I am quite willing to grant the desirability of taking such possibilities into consideration. But, at the same time, it seems all the less likely that the actual occurrence of the Bacteria is explicable on these grounds, because we find them developing just as freely within the cells freshly cut from the centre of a tuberous root, or we may find them already developed within these cells, if the root has begun to decay. To suppose that actual germs of Bacteria and of Torula are uniformly distributed throughout the tissues of higher organisms, is to harbour a hypothesis which would appear to many to be devoid of all probability-more especially when the heterogenetic mode of origin of larger and higher organisms is a matter of absolute certainty. 


\section{ORIgin of Bacteria AND OF TORUle by ARCHEbiosis.}

The evidence on this part of the subject is, I think, sharply defined and conclusive. Simple experiments can be had recourse to, which are not admissible in the discussion of the question as to the origin of Bacteria and Tomula by Heterogenesis. There, we wish to establish the fact that living matter is capable of undergoing a certain metamorphosis, and consequently, we must deal with living matter. Here, however, with the view of establishing the fact that living matter can arise de novo, if we are able, shortly after beginning our experiment, to arrive at a reasonable and wellbased assurance that no living thing exists in the hermetically sealed experimental vessel-if the measures that we have adopted fully entitle us to believe that all living things which may have pre-existed therein have been killed-we may feel pretty sure that any living organisms which are subsequently found, when the vessel is broken, must have originated from some re-arrangements which had taken place amongst the not-living constituents of the experimental solutions, whereby life-initiating combinations had been formed.

The possibility of the de novo origination of Bacteria, Torula, and other such organisms, is one which is intimately associated with the doctrine as to the cause of fermentation and putrefaction. With regard to the almost invariable association of such organisms with 
some of these processes, almost all are agreed. 'There is, moreover, a very frequent association of particular kinds of organisms with particular kinds of fermentation. Hence the assumption is an easy and a natural one to many persons, that the organisms which are invariably met with in some cases are the causes of these fermentations, ${ }^{*}$ although it is quite obvious that the facts on which this view is based, are equally explicable on the supposition that the organisms are concomitant results or products (due to new chemical combinations) of the fermentative changes. In the one case the fermentative changes are believed to be initiated by the influence of living organisms; and those who regard living things as the only true ferments, for the most part also believe that living things are incapable of arising de novo. They think that those organisms which serve to initiate the changes in question, have been derived from a multitudinous army of omnipresent atmospheric germs, which are always ready, in number and kind suitable for every emergency. This is the doctrine of M. Pasteur and others. On the other hand, fermentations and putrefactions may be regarded as sets of chemical changes, which are apt to occur in organic and other complex substances-these changes being due either to the intrinsic

* From this view the transition is also easy, though none the less illegitimate, to the doctrine that all fermentations are caused by organisms ; just as it has been easy to start, and find converts for, the doctrine expressed by the phrase "omne vivum ex vivo." The distinction between all and some is only too often overlooked. 
instability of the body which manifests them, or to molecular movements communicated to it by a still more unstable body. Baron Liebig says:-_ Many organic compounds are known, which undergo, in presence of water, alteration and metamorphosis, having a certain duration, and ultimately terminating in putrefaction; while other organic substances that are not liable to such alteration by themselves, nevertheless, suffer a similar displacement or separation of their molecules, when brought into contact with the ferments."

Each substance belonging to the first class, would be at the same time, therefore, both ferment and fermentable substance; whilst a small portion of such substance, when brought into contact with a less unstable substance, might induce such molecular movements as to make it undergo a process of fermentation. With regard to the cause of such induced fermentative changes, Gerhardt* says, in explaining Liebig's views: - "Every substance which decomposes or enters into combination is in a state of movement, its molecules being agitated; but since friction, shock, mechanical agitation, suffice to provoke the decomposition of many substances (chlorous acid, chloride of nitrogen, fulminating silver), there is all the more reason why a chemical decomposition in which the molecular agitation is more complete, should produce similar effects upon certain substances. In addition, bodies are

* 'Chimie organique,' 1856 , t. iv. p. 589. 
known which when alone are not decomposed by certain agents, but which are attacked, when they exist in contact with other bodies incapable of resisting the influence of these agents. Thus platinum alone does not dissolve in nitric acid, but when allied with silver, it is easily dissolved ; pure copper is not dissolved by sulphuric acid, but it does dissolve in this when it is allied with zinc, \&c. According to M. Liebig it is the same with ferments and fermentable substances; sugar, which does not change when it is quite alone, changes-that is to say ferments-when it is in contact with a nitrogenous substance undergoing change, that is, with a ferment."

Thus, in accordance with this latter view, living ferments are not needed-mere dead, organic or nitrogenous matter suffices to initiate the processes in question.* Those who hold this opinion may or may not believe that organisms are capable of arising de novo; $\uparrow$ though there can be little doubt that a

* Those who hold this opinion do not of course deny that living ferments can initiate fermentations. Every-day experience convinces them of the truth of this. They merely affirm that the intervention of vital action is not essential : they look upon fermentation as a purely chemical process, and believe that even in those cases where fermentation is initiated by living organisms (such as beer-yeast), these-although living-act chemically upon the matter which undergoes fermentation.

† They may not believe this, because they may be unaware of the fact of the invariable association of some organisms with some kinds of fermentations, and may consequently have never concerned themselves with the evidence bearing upon this part of the question. (See Gerhardt, loc. cit.) 
belief in the truth of such a doctrine does, almost inevitably, entail a belief in the de novo origination of living things. No one who has looked into the evidence, doubts the fact of the association between some of these processes and the presence of organisms; the only question is, as to the relation in which they stand to one another. If organisms are not the causes of those fermentative changes with which they are invariably associated, then they are, in all probability, the results of such changes; and they must certainly have been produced de novo if it can be shown that fermentation or putrefaction may take place under the influence of conditions which make it certain that pre-existing living organisms could have had nothing to do with the process.

Now, in order to lend some air of probability to the former hypothesis, concerning the necessity for the existence of living ferments, it was incumbent upon its supporters to endeavour to show that the air did contain such a multitude of "germs," or living things, as were demanded by the requirements of their theory. Spallanzani and Bonnet had, as far as the imagination was concerned, done all that was necessary. They had proclaimed the universal diffusion of "germs" of all kinds of organisms throughout the atmosphere -which were ready to develop, whenever suitable conditions presented themselves. So far, however, this was but another hypothesis. To establish the doctrine that fermentation cannot take place without 
the agency of living ferments, we cannot receive hypotheses in evidence : facts are needed. These, no one attempted to supply in an adequate manner* anterior to the investigations of M. Pasteur. Speaking of his researches, even M. Milne-Edwards says, $\uparrow$ " Previous to this time, the existence of reproductive particles, or infusorial germs in the atmosphere was nothing more than a plausible hypothesis, put forward in order to explain the origin of such creatures in a manner conformable with the general laws of reproduction; but it was only a mere supposition, and no one had been able actually to see or to handle these reproductive corpuscles."

We have to look, therefore, to M. Pasteur's investigations, and to others which may have been since conducted, for all the scientific evidence in support of what has been called the "Panspermic hypothesis."

By an ingenious method of filtration, which is fully described in his memoir, $\ddagger$ M. Pasteur separated from the air that passed through his apparatus the solid particles which it contained. This search convinced him that there were, as he says, "constantly in ordinary air a variable number of corpuscles whose form

* M. Pouchet and others had examined the dust which settles on objects, and amongst much débris of different kinds had found comparatively few ova or spores. He had not, however, up to this time, filtered the air, so as to see what germs might be detected floating about in the atmosphere.

† 'Anat. et Physiol. compar.' t. viii. p. 264.

‡'Annales de Chimie et de Physique,' I862, t. lxiv. p. 24. 
and structure declare them to be organized." Some of these, he thinks, resemble the spores of fungi, and others the ova of ciliated infusoria, though he adds :"But as to affirming that this is a spore, much less the spore of any definite species, and that one is an egg, and belonging to such an infusorium, I believe that this is not possible." He limits himself, in fact, to the statements, that the corpuscles which he found, were (in his opinion) evidently organized; that they resembled in form and appearance the germs of the lower kinds of organisms; and that, from their variety in size, they probably belonged to many different sorts of living things. Even here, therefore, we have to do with the impressions of M. Pasteur, rather than with verified statements. All that has been established by his direct investigation as to the nature of the solid bodies contained in the atmosphere is this: that the air contains a number of round or ovoidal corpuscles, often quite structureless, which he could not distinguish from the spores of fungi*some of which, being about the right size, were round or ovoidal, and structureless. In addition, however, it has been shown that the air contains other rounded corpuscles which are similarly structureless, though composed of silica or starch. It may therefore be asked, in the first place, whether the conclusion is

* Those which he believed to be eggs of ciliated infusoria, may be at once dismissed from consideration, as we are not at present concerned with the origin of organisms of this kind. 
a sufficiently safe one that many of the corpuscles found by M. Pasteur were spores of fungi; and in the next place, supposing this to have been established, whether such spores were living or dead. These questions would have been answered satisfactorily if M. Pasteur could state that he had actually watched the development of such corpuscles, in some suitable apparatus, into distinct organisms. But any such development, he distinctly states, he never witnessed. He says*:- "What would have been the better and more direct course would have been to follow the development of these germs with the microscope. Such was my intention; but the apparatus which I had devised for this purpose not having been delivered to me at a convenient time, I was diverted from this investigation by other work." The evidence which he does adduce, in subsequent portions of his memoir, in order to prove that some of these corpuscles were really "fertile germs," is almost valueless, because all the facts are open to another interpretation, which is just as much, nay, even more, in accordance with Baron Liebig's than with his own doctrine of fermentation.

But another most important consideration presents itself. M. Pasteur's researches as to the nature of the dust contained in the atmosphere enable him to say nothing concerning the presence of Bacteria, although he himself admits that these are generally

* Loc. cit. p. 34, note ${ }^{1}$. 
the first organisms which display themselves in fermentations or putrefactions, and that in a very large majority of the cases in which fermentation occurs in closed vessels they are the only organisms which make their appearance.* And yet, notwithstanding these facts, M. Pasteur says, in reference to the common form of Bacterium:-" This infusorial animal is so small that one cannot distinguish its germ, and still less fix upon the presence of this germ, if it were known, amongst the organized corpuscles of the dust which is suspended in the air."

Here, then, we have a confession from M. Pasteur himself, that all evidence fails, where it is most wanted, in support of his hypothesis.

If a large number of fermentations begin with the presence of Bacteria as the only living things, and if in a number of cases no other organisms ever occur, it is useless to adduce as evidence, in proof of the view that fermentations are always initiated by air-derived organisms, the fact that certain corpuscles (supposed to be spores of fungi) are recognizable in the atmosphere - capped by the distinct statement $\uparrow$ that Bacteria or their germs are not recognizable. If Bacteria are not recognizable in the atmosphere, what scientific evidence is there that the fermentations in which these alone occur are initiated by Bacteria derived from the atmosphere, or from certain imagi- 
nary Bacteria germs, ${ }^{*}$ which we are supposed to be unable to distinguish? M. Pasteur may, moreover, be reminded that when he resorts to the supposition of Bacteria possessing "germs", which are indistinguishable, he is again resorting to hypothesis rather than to fact, in order to prove the truth of the particular doctrine of fermentation which he advocates. Bacteria are known to reproduce and multiply only by a process of fission; each of the parts into which they divide being nothing more than a part of the original Bacterium, and therefore endowed with similar properties of resisting heat, desiccation, and other agencies. Any resort to invisible germs to account for the multiplication of Bacteria, which are known to reproduce freely in other ways, is obviously not permissible, unless such postulation be more or less necessitated by the occurrence of facts otherwise inexplicable.

* M. Pasteur's use of this term, in which he is followed by others holding similar opinions, is much to be deprecated. Having said that he had found certain corpuscles which resembled spores of fungi, or ova of infusoria, he subsequently speaks of them as "germs," and also applies the same name to the reproductive particles of Bacteria, which he merely assumes to be present in the atmosphere. Thus, having only proved that corpuscles resembling spores of some fungi, are to be found in the atmosphere, he subsequently speaks of the presence of a multitude of atmospheric germs as an established fact, without at all prominently pointing out that, so far as the most important of these are concerned-germs of Bacteria-their existence had only been inferred, and not proved. 
Although, therefore, no direct evidence has been adduced tending to show that Bacteria are present in the atmosphere, even if this evidence had been forthcoming, it would have been necessary, in reference to M. Pasteur's hypothesis, for it to be supplemented by further evidence to the effect that Bacteria were well capable of resisting such an amount of desiccation as must have been involved by their presence for an indefinite time in the atmosphere even of the hottest and driest regions of the earth. For, organic substances in solution do not only putrefy in moist weather or moist climates ; they putrefy most rapidly and surely when the temperature is high, and quite irrespectively of the amount of moisture contained in the atmosphere. A property of resisting the effects of desiccation - the possession of which, by Bacteria, is so necessary for the truth of M. Pasteur's argument-ought to have been shown by scientific evidence to be a real attribute of such organisms; though it seems, on the contrary, to have been assumed to exist, with almost equal readiness by both parties, in the controversies concerning the possibility of "spontaneous generation." This error may be ascribed to the misguiding influence of a treacherous analogy. Whilst it may be true that certain seeds and spores, and also that Rotifers, "Sloths," and some Nematoids are capable of resisting the influence of a prolonged exposure to desiccating influences, it may well be asked, whether the same fact necessarily holds 
good for organisms such as Bacteria, which have no chitinous or other envelopes to protect them, and which are merely minute fragments of naked protoplasm. Having elsewhere* shown how far presumptions had stolen a march upon established facts, in reference to the supposed possession of a similar property by the Free Nematoids, my eyes were opened to the reality of this uncertainty with regard to Bacteria. It is, however, no easy matter definitely to prove or to disprove the possession of this property by organisms so minute as Bacteria, and therefore so difficult to identify. If dried Bacteria are added to a drop of a suitable solution-sinilar to that in which they had been bred-it soon becomes quite impossible to distinguish those which have been added from those which arise in the fluid. Taking into consideration the fate of other simple organisms, however, it is by no means improbable that they should be killed even by a short desiccation. I have found, for instance, that desiccation for half-an-hour in a room at a temperature of $65^{\circ} \mathrm{F}$. suffices to kill all the larger, naked, lower organisms with which I have experimented-including long Vibrios, Amæbæ, Monads, Chlamydomonads, Euglenæ, Desmids, Vorticellæ and all other Ciliated Infusoria.

But, certain indirect evidence seems to speak most authoritatively against the supposition that the

* 'Philosophical Transactions,' i 866, pp. 616-619. 
air contains any notable quantity of living Bacteria, or Bacteria germs, whether visible or invisible. I have always found that a simple solution of ammonic tartrate, which has been placed-without previous boiling-in a corked bottle of greater capacity, will become turbid in two or three days, owing to the presence of myriads of Bacteria; whilst a similar solution, previously boiled, may remain for ten days, three weeks, or more, without showing the least trace of turbidity, although the open neck of the bottle or flask in which it is contained, may be covered only by a loose cap of paper. And yet, at any time, in order to make this fluid become turbid in from 24 to 48 hours, all that one has to do is to bring it into contact with a small glass rod which has just been dipped into a solution containing living Bacteria.*

If we find that an eminently inoculable fluid will remain for two or three weeks, or perhaps more, in contact with the air without becoming turbid, though it will always become turbid in two or three days if brought into contact with living Bacteria, what can we conclude, but that living Bacteria are not very common in the atmosphere? These most striking facts can be easily verified by other observers.

Thus we find ourselves, at present, in this position. After all that has been said and done to prove the wonderful prevalence of "germs" in the atmosphere,

* The solution, during the whole time, being exposed to a temperature of $75^{\circ}$ to $85^{\circ} \mathrm{F}$. 
we are really still in the region of hypothesis-no further advanced than we were in the time of Bonnet and of Spallanzani, so far as it concerns the organisms which are all important-Bacteria. Neither these nor their germs have been shown to exist in any recognizable abundance in the atmosphere, and yet in most fermentations they are the first organisms which display themselves; whilst in many such fermentations Bacteria alone occur. Nay more, even were they present in any great abundance, there is some reason to believe that the majority of them would exist as mere dead, organic particles-because Bacteria are more than likely to be unable to resist anything like an extreme or prolonged exposure to desiccating influences.

The first and essential data in support of M. Pasteur's hypothesis must, therefore, be regarded as entirely unproved in respect to Bacteria-which are the most important of all organisms, in relation to the cause of fermentation and putrefaction.

Without the aid of elaborate experiments, however, the evidence which the microscope can supply is capable of leading us to the conclusion that such search for atmospheric Bacteria germs, was comparatively useless. If it can be shown that Bacteria can arise in a.fluid independently of visible germs, then, obviously, any inquiries as to the nature of the visible contents of the atmosphere, can have only a very indirect bearing upon the question as to the 
mode of origin of these organisms. And yet by the aid of the microscope, as I have elsewhere stated, one can watch the appearance of almost motionless specks, more or less uniformly diffused through a motionless film of fluid, and can see them gradually develop into moving Bacteria or into Torula. So that, where no visible germs previously existed, visible particles of living matter develop, and more or less rapidly grow into distinct Bacteria. This may be best seen in a drop of a fresh and very strong turnip infusion, which has been filtered several times through the finest paper. The drop, placed in a live-box, should be flattened into a thin film by the application of the cover.

Thus protected, evaporation takes place very slowly, and with the live-box resting on one of Stricker's hot-water plates, at a temperature of $85^{\circ}$ to $90^{\circ} \mathrm{F}$, and the latter upon the stage of the microscope, one can easily select a portion of the field in which either no particles or only a countable number exist. If, therefore, around and between any mere granules which may pre-exist, or in a clear space, one gradually sees in the course of two or perhaps three hours, a multitude of almost motionless specks (at first about $\frac{1 ? " \text { ? }}{10000}$ in diameter) in positions where no such specks previously existed; and if these specks may be seen gradually to increase in size and develop into Bacteria and Torula, then, at all events, we are able to say that these organisms can be developed without pre-existing visible germs, and we have 
just the same amount of actual evidence for believing that they have been formed de novo, as we should have for believing that crystals had been formed $d e$ ' novo, if we had seen them appearing under our eyes in the same manner. Whether they really arise after the fashion of crystals, without the aid of pre-existing though invisible germs, is a matter which can only be settled inferentially, by a subsequent resort to strict methods of experimentation.

Seeing however, that we are able, with the aid of the microscope alone, to demonstrate that Bacteria and Torula can develop in situations where no visible germs had previously existed, it is useless, as I have said before-so far as the question of their mode of origin is concerned-to search the atmosphere to ascertain what visible germs it may contain. If some $\mathrm{Bac}$ teria and Torula arise from germs at all, it must be from germs which are invisible to us. The finding of visible germs in the atmosphere can, therefore, only have an indirect bearing upon the solution of the problem. Since it can be shown that some visible spores and ova exist in the atmosphere, this affords a certain amount of warrant for the supposition that invisible, living, reproductive particles may also exist-more especially if the existence of an amount of organic matter, which is ordinarily invisible, can be revealed in the air, by the agency of the electric beam, or by any other means.

Nothing can be more illegitimate, however, in the 
way of inference, than the assumption at once indulged in by Prof. Tyndall and others (who might have been expected, by their previous scientific work, to have learned more caution) that this impalpable organic dust was largely composed of impalpable germs. Yet, with. out a shadow of proof, without even an attempt to prove it, the air was for a time represented to be a mere stirabout, thick with invisible germs. The briefest reflection, however, upon the probabilities of the case, should have sufficed to suggest a totally different interpretation. The surface of the earth is clothed with living things of all kinds, animal and vegetal, which are not only continually throwing off organic particles and fragments during their life, but are constantly undergoing processes of decay and molecular disintegration after their death. The actual reproductive elements of these living things are extremely small in bulk, when compared with the other parts which are not reproductive, and although Bacteria and Torula do exist abundantly, and do materially help to bring about some of the decay in question, yet their bulk, also, is extremely small in comparison with the amount of organic matter itself that is continually undergoing disintegration of a dry kind, in which Bacteria and Torula take no part. When, moreover, it is considered that in the neighbourhood of populous cities (the air of which alone exhibits this very large quantity of impalpable, mixed with palpable, organic dust), there is constantly going on a wear and tear of 
the textile fabrics and of the organic products of various kinds which are daily subservient to the wants of man; and that the chimneys of manufactories and dwelling-houses are also continually emitting clouds of smoke thick with imperfectly consumed organic particles, some idea may be gained of the manifold sources whence the organic particles and fragments found in the atmosphere may emanate, and also as to what proportion of them is likely to be composed of living or dead reproductive elements, or "germs."

Thus, then, so far as the two rival doctrines of fermentation are concerned, the investigation of the nature of the solid particles contained in the atmosphere has revealed facts which are thoroughly in harmony with all the requirements of Liebig's physical theory, though it has almost utterly failed to give. anything like a scientific basis to the vital theory of Pasteur. So far from being able to show that living Bacteria (which are the first and oftentimes the only. organisms concerned in many processes of fermentation and putrefaction) are universally diffused through the air, Pasteur admits that these cannot be detected, and that their "germs" are not recognizable.

If, therefore, M. Pasteur still maintains the truth of his theory, it should be distinctly understood that it rests originally, not upon established facts, but upon a mere hypothesis-the hypothesis that the air teems with multitudes of invisible Bacteria germs. $\mathrm{He}$ is driven to such a doctrine, not only by his own con- 
fessions concerning Bacteria, but also by the microscopical evidence to which I have referred.

So that in explaining the results of any experiments made with the view of throwing light upon the cause of fermentation or putrefaction, it is especially necessary to bear in mind two considerations :-

I. That dust filtered from the atmosphere cannot be proved to include living Bacteria; though it is known to contain a multitude of organic particles which may be capable in the presence of water, in accordance with Liebig's hypothesis, of acting as ferments.

II. It must also be recollected that, in the opinion of many, Life represents a higher function which is displayed by certain kinds of organic matter; and that this higher function may be deteriorated or rendered non-existent by an amount of heat which might not be adequate to decompose the organic matter itself.

It is all the more necessary to call attention to these two considerations, because M. Pasteur invariably speaks as though it had been established that the air contains multitudes of living Bacteria, when, really, he had only proved that the air contains a number of corpuscles resembling spores of fungi, \&c. And, as I have already intimated, the existence of spores of fungi in the atmosphere, however well established, is of little or no importance as an explanation of the cause of a very large number of fermentations. Their presence is even of still less importance, owing to the fact of the co-existence with 
these fungus-spores, of multitudes of organic fragments, which-in accordance with the views of Liebig, Gerhardt, and other chemists-are capable of acting as ferments. To this latter consideration M. Pasteur never even alludes when he speaks (loc. cit. p. 40) of his "ensemencements," and of other experiments which are equally, or even more, capable of being interpreted in accordance with Liebig's views than with his own.

Bearing these considerations in mind, we shall be in a better position to enquire into the real interpretation that may be given to many of M. Pasteur's results, and into the question as to how far the facts which he records are favourable to his own, or to the adverse doctrine concerning the causes of fermentation.

In the memoir so often alluded to on "The Organized Corpuscles which exist in the Atmosphere," M. Pasteur adduced various kinds of evidence, tending, as he thought, to show that the first Bacteria which make their appearance in putrefying or fermenting solutions, have been derived from living Bacteria or their "germs," which pre-existed in the atmosphere.

Some of the experiments by which he endeavoured to substantiate this position were of a very simple nature. Their narration attracted much attention at the time, as it was supposed that by their means M. Pasteur had-as he professed-conclusively shown the erroneousness of the views of those who believed in what was called "spontaneous gene- 
ration." These experiments were soon repeated by other observers, who, using different fluids, obtained quite opposite results. Thus it became obvious to impartial critics, that whilst the means adopted by M. Pasteur might be adequate to check the processes of fermentation or putrefaction in certain fluids, they were quite powerless to effect this when many other fluids were employed.

These particular experiments, however, still seem to exercise a very great influence on the minds of many in this country, who are either unaware of, or disbelieve in, the possibility of obtaining opposite results.

The chapter in which M. Pasteur detailed these experiments is thus entitled:- "Another very simple method of demonstrating that all the organized products of Infusions (previously heated) owe their origin to the corpuscles which exist suspended in the Atmosphere." Whilst claiming to have already rigorously established the validity of this conclusion by the experiments described in previous chapters, M. Pasteur adds :- " If there remained the least doubt on this subject, in the mind of the reader, it would be dissipated by the experiments of which I am now about to speak." (p. 66.)

Sweetened yeast-water, urine, infusions of pear and of beetroot, were placed in flasks with long necks, variously drawn out and bent. The flasks were subsequently treated as follows. M. Pasteur says :- "I then raise the liquid to the boiling-point for several minutes until steam issues abundantly from the ex- 
tremity of the drawn-out neck of the flask, which is permitted to remain open. I then allow the flask to cool. But, singular fact-and one well calculated to astonish every one acquainted with the delicacy of the experiments relating to what is called 'spontaneous generation' - the liquid of this flask will remain indefinitely without alteration. The flask may be handled without any fear, it may be transported from place to place, allowed to experience all the seasonal variations of temperature, and its liquid does not undergo the slightest alteration, whilst it preserves its odour and its taste." If, however, the neck of one of these flasks be broken off close to the flask itself, then, according to M. Pasteur, the previously unaltered fluid will, in a day or two, undergo the ordinary changes, and swarm with Bacteria and Mucedince.

"The great interest of this method is," M. Pasteur adds, "that it completes, unanswerably, the proof that the origin of life in infusions which have been raised to the boiling point, is solely due to the solid particles* which are suspended in the air." He believes that any living things pre-existing in the fluid itself would be destroyed by the high temperature to which it had been raised ; and that those contained in the air of the flask would also be destroyed, if not expelled, by the process

* As expressed, the proposition may be an approximation to the truth. M. Pasteur, however, really endeavours to lead his readers to believe that the "solid particles" which are efficacious, are, in all cases, living "germs." 
of ebullition. Believing that the air is the source of germs from which Life is first developed in infusions, he thinks that what rapidly enters at first, on the cessation of ebullition, has its germs destroyed by contact with the almost boiling liquid; whilst the air which enters subsequently, and more slowly, is supposed to deposit its germs in the various flexures of the tubes, so that none are able to reach the fluid itself. Infusions, thus protected, do not undergo putrefaction, says M. Pasteur, because the access of preexisting living things is necessary for the initiation of this change, and such access is prevented by the tortuous and bent neck of the flask.

Others say that some fluids submitted to the conditions mentioned, will undergo putrefactive changes, and that, therefore, these experiments of M. Pasteur are utterly incapable of settling the general question as to the cause of fermentation and putrefaction, and also that concerning the origin of Life. Although acknowledging a certain difficulty in explaining the results which are sometimes attained by this method, some of us would rather confess this than confidently offer explanations-as M. Pasteur did-which may in a short time be stultified by the results of other experiments with different fluids.

Having previously shown* that living things could appear and multiply in such a flask as M. Pasteur

* 'Nature,' I870, No. 36, p. 193. 
describes - in any flask, in fact,- which had been hermetically sealed during the ebullition of a suitable fluid within; this was deemed to be a result so contradictory to the explanations of M. Pasteur, that it appeared needless to add my testimony, as I could have done, to that of M. Victor Meunier and others, as to the different results obtainable by operating, in M. Pasteur's fashion, with different fluids. It seemed to me that if organisms were to be procured in flasks from which air had been altogether expelled, it was useless still to urge the preservative virtues of any process of filtration of air-with the object of showing that living things in infusions derived their origin from atmospheric germs. Obviously, if there were no atmosphere, there could be no atmospheric germs present; and if living things were, nevertheless, developed under these exclusive circumstances, how could M. Pasteur or his disciples still expect to convince others that the first living things in infusions always proceeded from preexisting atmospheric germs-even although it could be shown, that in many cases, when these were filtered off by flasks with narrow and tortuous necks, no living things were developed in such fluids. Granting to the full the truth of such facts, they could do nothing to establish the doctrine of the origin of infusorial life from pre-existing atmospheric germs, so long as it could also be shown that living things might be developed in boiled solutions to which air, instead of being filtered, was never allowed to enter at all. 
It is not, therefore, because I think that some of the experiments which will subsequently be related afford any stronger or more direct support to my own conclusions, but because I think they may do this indirectly-by shaking the faith of many in some of the reasonings of $\mathrm{M}$. Pasteur-that $\mathrm{I}$ am induced to give an account of them.*

What has been hitherto said, also applies to the more recent statements concerning the efficacy of cotton-wool as an agent for filtering germs from the atmosphere. Prof. Huxley says he has never seen putrefaction or fermentation occur after certain organic fluids have been boiled for ten or fifteẹn minutes, if a good plug of cotton-wool has been inserted into the neck of the flask in which they are contained whilst ebullition is going on, and has, subsequently, been allowed to remain in the same situation. Using other or perhaps stronger fluids, however, I have found that such a method of proceeding is by no means adequate to stop the growth and development of organisms. And, also, even if it had been always efficacious - the reason adduced could not hold good, in the face of my other experiments, which had shown that a development of life might go on in cases where the air, which had been similarly driven out, was subsequently, in place of

* If his reasonings can be shown to be quite inconclusive, and if his results can be otherwise explained, some people may, at last, begin to recognize that their blind and mistaken faith M. Pasteur's work has been somewhat misplaced. 
being filtered, prevented from gaining access to the fluid.

If germs derived from the air are the sole causes of putrefaction, then, surely, deprivation from air ought to be just as efficacious as any process of filtration of air-more especially when the filtration or the deprivation have a common starting point. And the mode of procedure, in both cases, is precisely the same up to a certain point. A fluid is boiled for a short time in order to kill the germs which may be within the flask, and to expel its previously contained air. At a certain stage of the ebullition, this may be arrested, if we have to do with a bent-neck flask, or one whose neck is plugged with cotton-wool, and no change, it is said, will subsequently take place in the contained fluid, because the air which enters is, by either of these means, filtered from its germs. But if, whilst ebullition continued, the neck of the flask had been hermetically sealed-so as altogether to prevent the re-ingress of air-and if the fluid, thus contained in vacuo, would nevertheless undergo fermentation, obviously the former explanation must be altogether shelved.

In the face of M. Pasteur's explanations, and those of Professor Huxley, these frequent positive results with fluids contained in vacun are absolutely contradictory. There may naturally arise, therefore, a very grave doubt as to the validity of the explanation adduced by M. Pasteur, and adopted by Professor Huxley and others. 
All these experiments to which I have been alluding are based upon the supposition (assented to by Pasteur and Huxley) that Bacteria which pre-existed in the solution would certainly be destroyed by its being raised for a few minutes to a temperature of $212^{\circ} \mathrm{F}$. This conclusion is, I believe, perfectly correct,* and in support thereof I will adduce the following additional information.

\section{Limits of 'Vital Resistance' to Heat displayed by Bacteria and Torulce.}

After stating elsewhere $t$, that Vibriones are partly broken up or disintegrated by an exposure for a few minutes to a temperature of $212^{\circ} \mathrm{F}$. in an infusion which is being boiled, and also that, in all probability, the life of Bacteria would be destroyed by such a treatment, I made the following remarks:- "With reference to these organisms, however, one caution is necessary to be borne in mind by the experimenter. The movements of monads and Bacteria may be, and frequently are, of two kinds. The one variety does not differ in the least from the mere molecular or Brownian movement, which may be witnessed in similarly minute, not-living particles immersed in fluids. Whilst the other seems to be purely vital-

* M. Pasteur attempted to make a distinction in the case of slightly alkaline or neutral fluids (loc. cit., pp. 6o-65). I have endeavoured to show the untenability of his conclusion in 'Nature,' I870, No. 37, pp. 224-227.

† 'Nature,' 1870, No. 35, p. 17 I. 
that is, dependent upon their properties as living things. These vital movements are altogether different from the mere dancing oscillations which notliving particles display, as may be seen when the monad or Bacterium darts about over comparatively large areas, so as frequently to disappear from the field. After an infusion has been exposed for a second or two to the boiling temperature, these vital movements no longer occur, though almost all the monads and Bacteria may be seen to display the Brownian movement in a well-marked degree. They seem to be reduced by the shortest exposure to a temperature of $100^{\circ} \mathrm{C}$. to the condition of mere not-living particles, and then they become subjected to the unimpaired influence of the physical conditions which determine these movements." I now have various facts to add in confirmation of these conclusions, and in extension of our knowledge concerning the vital resistance to heat of Bacteria and Torula.

It would be a most important step if we could ascertain some means by which these primary movements of living Bacteria might be distinguished from the secondary, or communicated, movements of notliving particles. In many cases, organisms that are truly living may only exhibit very languid movements, which, as movements, are quite indistinguishable from those that the same Bacteria may display when they are really dead. Because the movements, therefore, are of this doubtful character, persons are apt, unfairly, 
to argue that the Bacteria which present them, are no more living than are the minute particles of carbon obtained from the flame of a lamp, which may exhibit similar movements. This, however, is a point of view which becomes obviously misleading if too much stress is laid upon it; and it is more especially so in this case, when those Bacteria which display the most characteristic sign of vitality-viz., "spontaneous" division or reproduction - do, at the time, almost always exhibit only the same languid movements. Mobility is, in fact, not an essential characteristic of living Bacteria, whilst the occurrence of the act of reproduction is the most indubitable sign of their life. It should be remembered, therefore, that any Bacteria which are almost motionless, or which exhibit mere Brownian movements, may be living, whilst those which spontaneously divide and reproduce, are certainly alive-whatever may be the kind of movement they present.

In any particular case, however, can we decide whether Bacteria, that have been submitted to a given temperature, and which exhibit movements resembling those known as Brownian, are really dead or living? If the movements are primary, or dependent upon the inherent molecular activity of the organism itself, they ought, it might be argued, to continue when the molecules of the fluid are at rest; if, on the other hand, they are mere secondary or communicated movements, impressed upon the organisms as they 
would be upon any other similarly minute particles, by the molecular oscillations of the fluid in which they are contained, then the movements ought to grow less, and gradually cease, as the fluid approaches a state of molecular rest-if this be attainable. Following out this idea, some months ago, I first tested the correctness of the assumption by experimenting with fluids containing various kinds of not-living particles; such as carbon-particles from the flame of a lamp, or freshly precipitated baric sulphate. However perfect may have been the Brownian movements when portions of these fluids were first examined beneath a coveringglass, they always gradually diminished, after the specimen had been mounted by surrounding the covering-glass with some cement or varnish. Thus prepared, no evaporation could take place from the thin film of fluid, and after one, three, four, or more hours - the slide remaining undisturbed-most of the particles had subsided, and were found to have come to a state of rest. In order still further to test these views, I took an infusion of turnip, containing a multitude of Bacteria whose movements were of the languid description, and divided it into two portions. One of these portions was boiled for about a minute, whilst the other was not interfered with. Then, after the boiled solution had been cooled, a drop was taken from each and placed at some little distance from one another on the same glass slip; covering-glasses half an inch in diameter were laid 
on, and the superfluous fluid beneath each was removed by a piece of blotting-paper. When only the thinnest film of fluid was left, the coveringglasses were surrounded by a thick, quickly-drying cement.* Examined with the microscope immediately afterwards, it was generally found that the Bacteria which had been boiled presented a shrunken and shrivelled aspect - whilst some of them were more or less disintegrated - though, as far as movement was concerned, there was little to distinguish that which they manifested, from that of their plumperlooking relatives which had not been boiled.

If the specimens were examined again after twentyfour or more hours, there was still very little difference perceptible between them, as regards their movements. And the same was the case when the specimens were examined after a lapse of some days or weeks. One important difference does, however, soon become obvious. The Bacteria which have not been boiled, undergo a most unmistakeable increase within their imprisoned habitat; whilst those which have been boiled, do not increase. The two films may be almost colourless at first (if the Bacteria are not veryabundant), but after a few days, that composed of unboiled fluid begins to show an obvious and increasing cloudiness,

* I always employ a solution of gum mastic and bismuth in chloroform. If a different varnish be employed, it is of course necessary to ascertain whether its application is injarious to the enclosed Bacteria. 
which is never manifested by the other. Microscopical examination shows that this cloudiness is due to a proportionate increase in the number of Bacteria.

Is the continuance of the movements of the organisms which had been boiled attributable to their extreme lightness, and to the slight difference between their specific gravity and that of the fluid in which they are immersed? I soon became convinced that this was one, if not the chief reason, when I found that Bacteria which had been submitted to very much higher temperatures, behaved in precisely the same manner as those which had been merely boiled, and also that other particles which-though obviously dead-had a similar specific lightness, also continued to exhibit their Brownian movements for days and weeks. This was the case more especially with the minute fat particles in a mounted specimen of boiled milk,* and also with very minute particles which were gradually precipitated $\uparrow$ from a hay infusion that had been heated to $302^{\circ} \mathrm{F}$. for four hours. Trials with many different substances, indeed, after a time convinced me that the most rapid cessation of Brownian movements

* If an unboiled specimen of milk be mounted, a multiplication of living particles takes place here and there amongst the fat globules, just as the multiplication of Bacteria occurs in a vegetable infusion; but in the boiled specimen no trace of such multiplication can ever be detected.

$\dagger$ Those particles which come to rest, in such cases, are always in contact with one or other of the contiguous surfaces of glass. 
in stationary films, ${ }^{*}$ occurred where the particles were heavy or large; and that the duration of the movement was more and more prolonged, as the particles experimented with, were lighter or more minute. So that, when we have to do with Bacteria, the minute oil globules of milk, or with other similarly light particles, the movements continue for an indefinite time, and are, in part, mere exponents of the molecular unrest of the fluid. They are always capable of being increased or renewed by the incidence of heat or other disturbing agencies.

In respect of the movements which they may exhibit, therefore, really living, though languid, Bacteria, cannot always be discriminated from dead Bacteria. Both may only display mere Brownian movements.

It becomes obvious, then, that in doubtful cases we ought not to rely very strongly upon the character of their movements, as evidence of the death of Bacteria-although these may frequently be of so extensive a nature as to render it not at all doubtful whether the Bacteria which display them are living. In the experiments which I am about to relate, we shall be able to pronounce that the Bacteria are living or dead, by reference to the continuance or cessation of their most essentially vital characteristic. If Bacteria fail to multiply in a suitable fluid, and under suitable con-

* The specific gravity of the fluid being constant. Where this is dense or viscid, as with glycerine, Brownian movements do not occur at all. 
ditions, we have the best proof that can be obtained of their death.

Having made many experiments with solutions of ammonic tartrate and sodic phosphate, I have almost invariably observed that such solutions-when exposed to the air without having been boiled-become turbid in the course of a few days owing to the presence of myriads of Bacteria and Vibriones, with some Torule. These organisms seem to appear and multiply in such a solution almost as readily as they do in an organic infusion. On the other hand, having frequently boiled such solutions, and closed the flasks during ebullition, I have invariably found, on subsequent examination of these fluids, that whatever else may have been met with, Bacteria and Vibriones were always absent. The difference was most notable, and it seemed only intelligible on the supposition that any living Bacteria or dead ferments which may have pre-existed in the solution, were deprived of their virtues by the preliminary boiling. These experiments also seemed to show that such solutions, after having been boiled, and shut up in hermetically-sealed flasks, from which all air had been expelled, were quite incapable of giving birth to Bacteria. The unboiled fluid, exposed to the air, might have become turbid, because it was able to nourish any living Bacteria which it may have contained, or because it was capable of evolving these de novo, under the influence of dead ferments whose activity had not been destroyed by heat. Hence we have 
a fluid which is eminently suitable for testing the vital resistance of Bacteria,-one which, although quite capable of nourishing and favouring their reproduction, does not appear capable of evolving them, when, after previous ebullition, it is enclosed in a hermetically sealed flask from which all air has been expelled. Three flasks were half-filled with this solution.* The neck of the first $(a)$ was allowed to remain open, and no addition was made to the fluid. To the second (b), after it had been boiled and had become cool, was added half a minim of a similar saline solution, which had been previously exposed to the air, and which was quite turbid with Bacteria, Vibriones and Torula. From this flask-after its inoculation with the living organisms-the air was exhausted by means of an air-pump, and its neck was hermetically sealed during the ebullition of the fluid, without the flask and its contents having been exposed to a heat of more than $90^{\circ} \mathrm{F}$. The third flask $(c)$ was similarly inoculated with living Bacteria, although its contents were boiled for ten minutes (at $212^{\circ} \mathrm{F}$.), and its neck was hermetically sealed during ebullition. The results were as follows:-the solution in the first flask $(a)$, became turbid in four or five days; the solution in the second $(b)$, became turbid after thirty-six hours ; whilst that in the third flask $(c)$, remained perfectly

* In the proportion of ten grains of neutral ammonic tartrate, with three grains of neutral sodic phosphate, to an ounce of distilled water. 
clear. This latter flask was opened on the twelfth day, whilst its contents were still clear, and on microscopical examination of the fluid no living Bacteria were to be found. This particular experiment was repeated three times with similarly negative results, although on two occasions the fluid was only boiled for one minute instead of ten.

It seemed, moreover, that by having recourse to experiments of the same kind, the exact degree of heat, which is fatal to Bacteria and Torule might be ascertained. I accordingly endeavoured to determine this point. Portions of the same saline solution, after having been boiled* and allowed to cool, were similarly inoculated with a drop $\uparrow$ of very turbid fluid, containing hundreds of living Bacteria, Vibriones, and Torula. A drying apparatus was fixed to an air-pump, and the flask containing the inoculated fluid was securely connected with the former by means of a piece of tight india-rubber tubing, $\ddagger$ after its neck had been drawn out and narrowed, at about two inches from the extremity. The flask containing

* It was necessary to boil the solution first, in order to destroy any living things or dead ferments which it might contain. It must contain one or the other, because an unboiled solution of this kind, in a corked bottle about half full, will always become turbid ; whilst, after it has been boiled, it may be kept indefinitely under similar conditions without becoming turbid.

$\dagger$ The proportion was one drop of the fluid, opaque with organisms, to an ounce of the clear solution.

$\ddagger$ Into which a piece of glass tube had been slipped to prevent collapse. 
the inoculated fluid was then allowed to dip into a beaker holding water at $122^{\circ} \mathrm{F}$, in which a thermometer was immersed. The temperature of the fluid was maintained at this point for fifteen minutes, ${ }^{*}$ by means of a spirit lamp beneath the beaker. The air was then exhausted from the flask by means of the pump, till the fluid began to boil; ebullition was allowed to continue for a minute or two, so as to expel as much air as possible from the flask, and then, during its continuance, the narrowed neck of the flask was hermetically sealed by means of a spirit-lamp flame and a blowpipe. Other flasks were similarly prepared, except that they were exposed to successively higher degrees of heat-the fluid being boiled off, in different cases, at temperatures of $131^{\circ}, 140^{\circ}, 149^{\circ}, 158^{\circ}$, and $167^{\circ} \mathrm{F}$. All the flasks being similarly inoculated with living Bacteria, Vibriones, and Torula, and similarly sealed during ebullition, they differed from one another only in respect to the degree of heat to which they had been submitted. Their bulbs were subsequently placed in a water bath, which during both day and night was maintained at a temperature of from $85^{\circ}$ to $95^{\circ} \mathrm{F}$. The results have been as follows:-The flasks whose contents had been heated to $122^{\circ}$ and $131^{\circ} \mathrm{F}$. respectively, began to exhibit a bluish tinge in the contained fluid after the first or second day; and

* Allowing even five minutes for the temperature of the $\mathrm{I}$ oz. of fluid to become equal to that of the bath, it would then have remained exposed to this amount of heat for about ten minutes. 
after two or three more days, the fluid in each became quite turbid and opaque, owing to the presence and multiplication of myriads of Bacteria, Vibriones and Torula; the fluids in the flasks, however, which had been exposed to the higher temperature of $140^{\circ}, 149^{\circ}$, $158^{\circ}$, and $167^{\circ} \mathrm{F}$., showed not the slightest trace of turbidity, and no diminution in the clearness of the fluid while they were kept under observation-that is, for a period of twelve or fourteen days. One kind of conclusion only is to be drawn from these experiments, the conditions of which were in every way similar, except as regards the degree of heat to which the inoculated fluids were subjected-seeing that the organisms were contained in a fluid, which had been proved to be eminently suitable for their growth and multiplication.* If inoculated fluids which have been raised to $122^{\circ}$ and $13 I^{\circ} \mathrm{F}$. for ten minutes, are found in the course of a few days to become turbid, then, obviously, the organisms cannot have been killed by such exposure; whilst, if similar fluids, similarly inoculated, which have been raised to temperatures of $140^{\circ}, 149^{\circ}, 158^{\circ}$, and $167^{\circ} \mathrm{F}$. remain sterile, such sterility can only be explained by the supposition that the organisms have been killed by exposure to these temperatures.

Some of these experiments have been repeated

* Fluids which had remained sterile would always, in the course of thirty-six or forty-eight hours after inoculation with living Bacteria, become more or less turbid. 
several times with the same results. On three occasions, I have found the fluid speedily become turbid, which had only been exposed to $\mathrm{I}_{3} \mathrm{I}^{\circ} \mathrm{F}$. for ten minutes, whilst on three other occasions I have found the inoculated fluid remain clear, after it had been exposed to a heat of $140^{\circ} \mathrm{F}$. for ten minutes.*

* There is, however, another point of extreme interest in connection with these experiments, bearing upon the supposed universal distribution of "germs" of Bacteria and other organisms, which I will now mention. One of the flasks, which had been exposed to $140^{\circ} \mathrm{F}$., and which had been hermetically sealed at this temperature, had its neck cracked (accidentally) about half an hour afterwards. Thinking it would be as well, notwithstanding this, to keep it and observe the result, its bulb was immersed in the same water-bath with the other flasks which had been prepared at the same time. Whilst the fluid in one of these which had been exposed to a heat of $\mathrm{I}_{3} \mathrm{I}^{\circ} \mathrm{F}$., became turbid in the course of a few days, this, which had been exposed to a heat of $140^{\circ} \mathrm{F}$. and whose neck was also extensively cracked, remained quite clear for seven days, although to such an extent exposed to the access of germs. Its eminent suitability for nourishing the germs of such organisms was also shown, because, on the seventh day, the fluid being still clear, the blade of a penknife was dipped into it, after having been previously immersed in a solution containing living Bacteria and Torula, and in thirty-six hours after this inoculation, the fluid had become turbid, owing to the presence of myriads of these organisms. So that even where obvious cracks occur, and the vacuum is altogether impaired by the consequent inrush of air, such air does not necessarily carry with it germs of Bacteria - which have been supposed to be universally diffused, and capable of passing through cracks so minute as to be invisible. These results, important as they are, have not at all surprised me, because one may frequently find a previously boiled solution of the kind under consideration, remaining free from turbidity for two weeks or more, although the neck of the flask has been merely covered by a loose paper-cap (see p. 30). 
In experimenting upon rather higher organisms, with which there is little difficulty in ascertaining, by microscopical examination, whether they are living or dead, I have found that an exposure even to the lower temperature of $\mathrm{I} 3 \mathrm{I}^{\circ} \mathrm{F}$. for five minutes, always suffices to destroy all signs of life in Vibrios, Amœbæ, Monads, Chlamydomonads, Euglenæ, Desmids, Vorticellæ, and all other Ciliated Infusoria which were observed, as well as in free Nematoids, Rotifers, and other organisms contained in the fluids which had been heated.

These results are quite in harmony with the observations and experiments of M. Pouchet and of Professor Wyman, as to the capability of resisting heat displayed by Vibriones and all kinds of ciliated infusoria. According to the former, ${ }^{*}$ the majority of ciliated infusoria are killed at, or even below, the temperature of $122^{\circ} \mathrm{F}$., whilst large Vibriones are all killed at a temperature of $\mathrm{I}_{3} \mathrm{I}^{\circ} \mathrm{F} . \dagger$ According to the observations of Professor Wyman, the motions of all ciliated infusoria are stopped at less than $130^{\circ} \mathrm{F}$., whilst Vibriones, taken from the most various sources, also seemed to be killed at temperatures between I $30^{\circ}-1364^{\circ} \mathrm{F}$. Similarly, we find Baron Liebig quite recently making the following remarks concerning a species of Torula:- "A temperature of $60^{\circ} \mathrm{C}$.

* 'Nouvelles Expériences,' etc., I 864, p. 38 .

$\uparrow$ 'American Journal of Science and Arts,' Oct. 1867. 
$\left[140^{\circ} \mathrm{F}\right.$. $]$ kills the yeast cells; after exposure to this temperature in water, they no longer undergo fermentation, and do not cause fermentation in a sugar solution. ... In like manner, active fermentation in a saccharine liquid is stopped when the liquid is heated to $60^{\circ} \mathrm{C}$., and it does not recommence again on cooling the liquid."

That the organisms in question-being minute naked portions of living matter - should be killed by exposure to the influence of a fluid at these temperatures will perhaps not seem very improbable to those who have attempted to keep their fingers for any length of time in water heated to a similar extent. With watch in hand I immersed my fingers in one of the experimental beakers containing water at $\mathrm{I}_{3} \mathrm{I}^{\circ} \mathrm{F}$., and found that, in spite of my desires, they were hastily withdrawn, after an exposure of less than five-and-twenty seconds.

Wishing to ascertain what difference there would be if the inoculated fluids were exposed for a very long time, instead of for ten minutes only, to certain temperatures, I prepared three flasks in the same manner-each containing some of the previously boiled solution, which, when cold, had been inoculated with living Bacteria, Vibriones, and Torule. These flasks and their contents were then submitted to the influence of the following conditions:-One of them was heated for a few minutes in a beaker containing water at $\mathrm{II} 3^{\circ} \mathrm{F}$, and then by means of the air-pump a partial vacuum was procured, till the fluid began to 
boil. After the remainder of the air had been expelled by the ebullition of the fluid, the neck of the flask was hermetically sealed, and the flask itself was subsequently immersed in the water of the beaker, which was kept for four hours at a temperature between I I $3^{\circ}$ and II $8 \frac{1}{2}^{\circ} \mathrm{F}$.* The two other flasks similarly prepared were kept at a temperature of I I $8 \frac{1}{2}^{\circ}-\operatorname{I} 27 \frac{1}{2}^{\circ} \mathrm{F}$. for four hours. In two days, the fluid in the first flask became slightly turbid, whilst in two days more the turbidity was most marked. The fluid in the two other flasks which had been exposed to the temperature of $\operatorname{I} 8 \frac{1}{2}^{\circ}-127 \frac{1}{2}^{\circ} \mathrm{F}$. for four hours, remained quite clear and unaltered during the twelve days in which they were kept in the warm bath under observation. These experiments seem to show, therefore, that the prolongation of the period of exposure to four hours, suffices to lower the vital resistance to heat of Bacteria and Torula, by $14 \frac{1}{2}^{\circ}-\mathrm{I} 8^{\circ} \mathrm{F}$.

Such experiments would seem to be most important and crucial in their nature. They may be considered to settle the question as to the vital resistance of these particular Bacteria, whilst other evidence points conclusively in the direction that all Bacteria, whencesoever they have been derived, possess essentially similar vital endowments $\dagger$. Seeing

* During nearly the whole of the time the temperature was kept at $I 13^{\circ} \mathrm{F}$. It only rose to the higher temperature for about ten minutes.

$\dagger$ The Bacteria and Vibriones with which Professor Wyman experimented were derived from different sources; and so far as 
also that the solutions have been inoculated with a drop of a fluid in which Bacteria, Vibriones, and Torule are multiplying rapidly, we must suppose that they are multiplying in their accustomed manner, as much by the known method of fission, as by any unknown and assumed method of reproduction. In such a fluid, at all events, there would be all the kinds of reproductive elements common to Bacteria, whether visible or invisible, and these would have been alike subjected to the influence of the same temperature. These experiments seem to show, therefore, that even if Bacteria do multiply by means of invisible gemmules as well as by the known process of fission, such invisible particles possess no higher power of resisting the destructive influence of heat than the parent Bacteria themselves possess. This result is, more-

I also have been able to ascertain, the Bacteria of different fluids are similarly affected by exposure to similar degrees of heat. Thus, if on the same slip, though under different covering glasses, specimens of a hay infusion, turbid with Bacteria, are nounted, (a) without being heated, $(b)$ after the fluid has been raised to I $22^{\supset} \mathrm{F}$. for ten minutes, and $(c)$ after the fluid has been heated to $140^{\circ} \mathrm{F}$. for ten minutes, it will be found that, in the course of a few days, the Bacteria under $a$ and $b$ have notably increased in quantity, whilst those under $c$ do not become more numerous, however long the slide is kept. Facts of the same kind are observable if a turnip infusion, containing living Bacteria, is experimented with; and the phenomena are in no way different if a solution of ammonic tartrate and sodic phosphate (containing Bacteria) be employed instead of one of these vegetable infusions. The multiplication of the Bacteria beneath the covering-glass, when it occurs, is soon rendered obvious, even to the naked eye, by the increasing cloudiness of the film. 
over, as I venture to think, in accordance with what might have been anticipated $\dot{\alpha}$ priori. Bacteria seem to be composed of homogeneous living matter, and any gemmule, however minute, could only be a portion of such living matter, endowed with similar properties.

Extent to which boiled Fermentable Fluids may be preserved in Vessels with Bent Necks, or in those whose Necks are guarded by a Plug of Cotton-Wool.

Having thus satisfied ourselves as to the truth of the conclusion that Bacteria are killed when the fluid containing them is boiled (at $212^{\circ} \mathrm{F}$.), we are in a position to proceed with the inquiry as to the evidence which exists in respect to the statements made by M. Pasteur, Professor Huxley, and others, that fermentable fluids which have been boiled, will not undergo fermentation, either in vessels whose necks have been many times bent, or in those into whose necks a plug of cotton-wool has been inserted during the ebullition of their contained fluid. Organisms are not found in such cases, they say, because the "germs" from which the low organisms of infusions are usually produced, are arrested either in the flexures of the tube or in the cotton-wool. As I have before stated, however, it is obvious that if this explanation be the correct one, the preservation should be equally well marked in all cases-quite irrespectively of the amount of albumenoid or other 
nitrogenous material which may be contained in the fluid. Any exceptions to the rule should at once suggest doubts as to the validity of the explanation.

It was shown * in 1865 by M. Victor Meunier that some fluids were preserved after having been boiled in a vessel of this kind, whilst others, submitted to the same treatment, speedily became turbid from the presence of Bacteria and other organisms. $\dagger$ By these experiments he ascertained that strong infusions did frequently change, whilst weak ones might be preserved; and that even a strong infusion might be prevented from undergoing change if the period of ebullition were sufficiently prolonged.

The fluids most frequently employed by M. Pasteur were yeast-water, the same sweetened by sugar, urine, infusion of beetroot, and infusion of pear.

Taking urine as a fair example of such a fluid, I have found that the statements of $M$. Pasteur and of Professor Lister are perfectly correct. This fluid may generally remain for an indefinite period in such ves-

* 'Compt. Rend.', t. lxi. p. Iо6o.

$\dagger$ When boiled solutions, containing mannite, with a little nitrate and phosphate of ammonia, were employed, they always remained sterile. Similar negative results followed the employment of ox-gall. Of three decoctions of beef with which M. Meunier experimented, the two stronger of them were found to contain swarms of Bacteria in about twelve days. Of three other flasks containing boiled urine, two also proved fertile. 
sels* without becoming turbid, or undergoing any apparent change. The same is generally found to be the case with an infusion of turnip, and occasionally an infusion of hay may be similarly prevented from undergoing fermentation. On the other hand, if the turnip-solution be neutralized by the addition of a little ammonic carbonate, or liquor potassæ; or, better still, if even half a grain of new cheese be added to the infusion before it is boiled, then I have found that the fluid speedily becomes turbid, owing to the appearance of multitudes of Bacteria. In an infusion to which a fragment of cheese had been added, I have seen a pellicle form in three days, which, on microscopical examination, proved to be composed of an aggregation of Bacteria, Vibriones, and Leptothrix filaments. A mixture of albuminous urine and turnipinfusion has also rapidly become turbid in a vessel of this kind owing to the appearance of multitudes of Bacteria, and so has a mixture containing one-third of healthy urine with two-thirds of infusion of turnip.

Other infusions have been boiled for ten minutes in a vessel with a horizontal neck two feet long, into which, during ebullition, a good plug of cotton-wool had been carefully pushed down for a depth of twelve or fourteen inches, and cautiously increased in quantity during

* I have employed flasks of about $\mathrm{I} \frac{1}{2} \mathrm{oz}$. in capacity, provided with necks two feet in length. In each case, after the flask has been half filled with the fluid, the neck has been bent eight times at an acute angle. 
the continuance of the ebullition; whilst immediately after the withdrawal of the heat, the plug was pressed closer, and all the outer unoccupied portion of the tube was rapidly filled up in the same manner.

Preserved in such a vessel, a specimen of urine remained unchanged; a hay-infusion also underwent no apparent alteration; whilst a very strong infusion of turnip became turbid in five days, and ultimately showed a large quantity of deposit.*

Thus the rules laid down by Pasteur and others are not universal, and therefore, as I have previously pointed out, the explanation which he adduced of the preservation of those particular fluids which remained unchanged is at once rendered doubtful. More especially is there room for doubt on this subject when, as I have found, the result of the experiment can be, within certain limits, predicated beforehand, according to the nature of the fluid employed. If all organisms proceed from pre-existing germs, and these can be filtered from the air by a certain mechanical contrivance, then, if it be alleged that it is on account of such filtration that certain boiled fluids do not change, all fluids placed under these conditions ought, on this theory, to be similarly preserved. Exceptional cases cannot be accounted for on this hypothesis. To

* These are the only experiments which I have performed with the very long plugs of cotton-wool, though in other previous trials with plugs about $I \frac{1}{2}$ in. long, I have several times obtained positive results. 
others, however, who say that organisms are capable of arising de novo, and that fermentation can be initiated without the agency of living things, the above facts appear quite natural. The more complex the nitrogenous or protein materials contained in a solution, the more is it fitted to undergo fermentative changes, which may be accompanied by the de novo origination of living things. Therefore the above results are just as compatible with the notions of M. Liebig and his school, as they are antagonistic to those of M. Pasteur. Certain fluids, it is found, do not undergo change; whilst other fluids, of a more complex description, will ferment under the influence of similar conditions. Prolonged ebullition also, by breaking up some of the more unstable compounds of a solution (those which most easily initiate these changes) will retard or prevent its fermentation.

The complete untenability of M. Pasteur's explanations are, however, best revealed by having recourse to a series of comparative experiments, in which portions of the same fluid are boiled for an equal length of time in vessels of different kinds, and are then subsequently submitted, in a water-bath, to the influence of the same temperature.

I have made many experiments of this kind with different solutions, some of which I will now record. Owing to the different behaviour of the same fluids under different conditions, we are enabled to draw some most important conclusions; and owing to the 
different behaviour of different fluids under these respective conditions, our attention is strongly drawn to other facts which ought considerably to influence our judgment as to the relative merits of the two doctrines concerning the cause of fermentation and putrefaction. 
COMPARATIVE EXPERIMENTS.

IN the following experiments, each fluid (unless a statement is made to the contrary) was boiled contimuously for ten minutcs, after having been placed in its flask. Then, with the neck either open, sealed, or plugged, the bulb of the flask was immersed in a water-bath maintained at a temperature of $80^{\circ}-95^{\circ} \mathrm{F}$. during both day and night.*

First Set of Experiments (I.-XV.).

a. Fluid exposed to Air in a Flask with a short Open Neck.

No. I.-Urine in twenty-four hours was still clear and free from deposit. In forty-four hours the fluid was very slightly turbid, and on microscopical examination Bacteria and Torula were found, though not in very great abundance. In sixty-eight hours the fluid was quite turbid.

No. II.-Hay Infusion in twenty-four hours was still clear. In forty-four hours the fluid was very turbid, and a drop on examination showed multitudes of Bacteria of different kinds, exhibiting languid movements. In sixty-eight hours the turbidity had become much more

* When infusions have been employed, these have all been made as strong as possible, and have been filtered before use. Warm water has been added in quantity just sufficient to cover the substance to be infused (cut into very small pieces), and the mixture has then been kept at a temperature of from $110^{\circ}-130^{\circ} \mathrm{F}$. for three or four hours. 
marked, and there was also a certain amount of sediment.

No. III.-Turnip Infusion in twenty-four hours showed a very slight degree of turbidity. A drop examined microscopically revealed a number of very minute, but very active, Bacteria. In forty-four hours the turbidity had become very well marked.

b. Fluid in contact with Ordinary Air and its Particles; Neck of Flask Sealed after the Fluid had become Cold.

No. IV.--Urine remained quite bright and clear during the fifteen days in which it was kept under observation in the water-bath.*

No. V.-Hay Infusion after forty-four hours showed a well-marked turbidity. In sixty-eight hours there was an increase in the amount of turbidity, and also some sediment. During the next forty-eight hours turbidity and sediment gradually increased, whilst the colour of the fluid (originally that of port wine) became several shades lighter. Except that it grew still lighter in colour, and that the amount of sediment increased, it underwent no further obvious change during the fifteen days in which it remained in the bath.*

No. VI.-Turnip Infusion underwent no change during the fifteen days in which it was kept in the bath under observation.*

c. Fluid in a Flask weith a Neck two feet long, and having Eight acute Flexures.

No. VII.-Urine remained quite bright and clear during the fifteen days in which it was kept under observation in the water-bath.*

* Flask still in my possession, unopened. 
No. VIII.-Hay Infusion remained bright and clear for twelve days. On the thirteenth day a very slight (almost inappreciable) sediment was seen, which scarcely underwent any obvious increase during the next eight days, though on the two following days (twenty-second and twenty-third) the turbidity became most obvious: much sediment was deposited, and the fluid assumed a much lighter colour.* (On the twenty-second day the temperature of the bath was raised to $100^{\circ} \mathrm{F}$., for two or three hours.)

No. IX.-Turnip Infusion remained for four days without undergoing any apparent change. Its neck was then accidentally broken at the fourth joint - a certain amount of fluid still filling the third joint. In this condition the flask was allowed to remain in the water-bath, and the fluid continued quite unchanged in appearance for five days. It was then boiled $\uparrow$ for three minutes, and the neck of the flask was hermetically sealed whilst the fluid was boiling. The flask being re-immersed in water-bath, the fluid continued quite clear for thirteen days. Its neck was then carefully heated in the spiritlamp flame till, when red-hot, the rapid inbending of the glass showed that the vacuum was still preserved. This being ascertained, the flask was, after a few minutes, replaced in the bath. The next day the temperature of the bath was allowed to go up to $100^{\circ} \mathrm{F}$. for three or four hours, and in the evening the fluid was observed to be very slightly turbid. In two days more (i.e., after sixteen days in vacuo) the

* Flask still in my possession, unopened.

† The vapour had lost all odour of turnip. Some of the fluid which splashed over was found to be still slightly acid. 
turbidity was well marked, and when the fluid was examined microscopically it was found to contain an abundance of very languid Bateria and Vibriones. On opening the flask there was an outrush of very fotid gas, and the reaction of the fluid was acid.*

1. Fluid in a Flask having a Neck two feet long, bent at right angles shortly above the bulb, and provided with a firm Plug of Cotton-Wool twelve inches in length.

No. X.-Urine remained quite bright and clear during the fifteen days in which it was kept under observation in the water-bath. +

No. XI.-Hay Infusion showed a very slight amount of sediment after forty-four hours, which seemed to increase somewhat during the next three days. The fluid afterwards appeared to undergo no further change, though it remained in the warm water-bath for fifteen days. +

No. XII.-Turnip Infusion in four days showed a wellmarked turbidity, and also very many flakes of a broken pellicle.t

* This experiment is very interesting in two or three respects. A neck of half the usual length-with only four bendings-sufficed to preserve the fluid for several days; and when this fluid (which had been in the bent-neck apparatus for nine days) was sealed up in the same flask during ebullition, it remained in vacuo for thirteen days without undergoing any apparent change, and then only became turbid under the influence of a higher temperature. Yet some of the same fluid, in a flask which was hermetically sealed during the first ebullition (No. XV.) behaved as such an infusion usually does, and became quite turbid in forty-eight hours.

$\dagger$ Flask still in my possession, unopened. 
e. Fluid (in vacuo) in a Flask, the Neck of which weras hermetically Sealed by means of the Blowpipe Flame during Ebullition.

No. XIII.-Urine in forty-four hours showed a very slight amount of sediment. During the next two days the sediment very slightly increased, but was still small in amount. At the expiration of fifteen days, no further increase in the turbidity having taken place, the fluid was examined. The vacuum was still partially preserved, as evidenced by the rapid inbending of a portion of the neck of the flask after it had been carefully made red-hot. When opened, the odour of the fluid was stale, but not fœetid, and its reaction was still faintly acid. On microscopical examination Bacteria and Torula were found in tolerable abundance.

No. XIV.-Hay Infusion in forty-four hours showed a very slight amount of turbidity. In sixty-eight hours the turbidity was most marked, and there was also a small amount of sediment. In another twenty-four hours it was noticed that the colour of the fluid had become much lighter, whilst the turbidity and sediment had increased. It subsequently continued in much the same state, and the flask was opened on the sixteenth day. The vacuum was found to be almost wholly impaired, whilst the odour of the fluid was sour, and not at all hay-like. On microscopical examination Bacteria, Vibriones, Leptothrix, and Tonule, were found in abundance, and the former were very active.

No. XV. - Turnip Infusion after forty-eight hours showed a well-marked turbidity. In seventy-two hours the turbidity was more marked, and there was a slight amount of sediment. The turbidity also increased during the 
next twenty-four hours ; though, after that, the infusion seemed to undergo no further change. The flask remained in the warm bath for fifteen days, when the fluid was examined. Its odour was not foetid, but was somewhat like that of baked turnip. Bacteria and Vibriones existed in abundance, though their movements were extremely languid.

Second Set of Experiments (XVI.-XXI.).

b. Fluid in contact with Ordinary Air and its Particles; Neck of Flask Sealed after the Fluid had become Cold.

No. XVI.-Simple Turnip Infusion in twenty-four hours had undergone no apparent change. In thirtysix hours there was slight turbidity, and in forty-eight hours this was most marked and uniform. When the flask was opened, after seventy-two hours, there was an outrush of very fotid gas; the reaction of the fluid was acid, and, when examined microscopically, it was found to contain multitudes of very languid Bacteria.

No. XVII.-Neutralized Infusion of Turnip $+\frac{1}{2}$ gr. of Cheese, ${ }^{*}$ in thirty-six hours showed a well-marked pellicle.t When the flask was opened, after seventy-two hours, there was a violent outrush of gas, though the fluid was still neutral. Portions of the thick pellicle were found, on microscopical examination, to be made up of Bacteria, Vibriones, and an abundance of long,

* The filtered infusion of turnip was neutralized by liquor potassæ. The cheese (Cheddar) was new and not in the least mouldy.

$\dagger$ The fluid itself being somewhat opaque, the first stages of increased turbidity from presence of Bacteria could not be detected. 
interlaced Leptothrix filaments. Bacteria also existed abundantly in the fluid, though their movements were very languicl.

c. Fluid in a Bent Neck Flask, having Eight acute Flexures.

No. XVIII.-Simple Turnip Infusion after forty-eight hours showed no change. It was kept in water-bath for twelve days, and during the whole of this time the fluid remained quite clear. The tube was then broken $\mathrm{I} \frac{1}{2}$ inch above the bulb (which was re-immersed in the bath), leaving the fluid exposed to the air through the straight open tube. The fluid at this time was odourless, and its re-action was still faintly acid.

The infusion remained thus exposed for six days without undergoing any apparent change. On the eighth day a very slight whitish sediment was noticed, which had increased in quantity by the tenth day, though there was still no trace of general turbidity. On the eleventh day some of the sediment was examined in a drop of the fluid, and it was found to be wholly composed of rather large Torula cells - the largest being about $\frac{1}{3000}$ in diameter, though all the smaller sizes were abundantly represented. Not a single Bacterium or Vibrio could be detected, and the fluid was still quite odourless.*

* This again is a most instructive experiment when compared with Nos. XVI. and XX., in which portions of the same infusion were employed. The results in No. IX. would lead us to believe that a vegetable infusion which does not ferment, does, nevertheless, undergo some changes in molecular composition, and this notion seems to derive confirmation from the present experiment. Some of the same solution which has been kept for a time (twelve days) from contact with atmospheric particles, subsequently, even when fully exposed to the air, undergoes no 
No. XIX.-Neutral Turnip Infusion $+\frac{1}{2}$ gr. of Cheese, showed no perceptible change in twenty-four hours, though in thirty-six hours there was a well-marked pellicle on the surface. When the neck of the flask was broken after seventy-two hours, the fluid was found to be very fœetid, whilst its re-action had become slightly acid. Portions of the pellicle were found to be made up by aggregations of Bacteria, Vibriones, and an abundance of Leptothrix filaments. The Bacteria all exhibited very languid movements.

c. Fluid (in vacuo) in a Flask which had been Sealed during Ebullition.

No. XX.-Simple Turnip Infusion in twenty-four hours showed a very slight amount of turbidity; in thirtysix hours this had increased, and in forty-eight hours there were multitudes of curdy flocculi floating in a tolerably clear fluid. The flask was opened after seventy-two hours, when there seemed to be only a very slight inrush of air. The odour of the fluid was somewhat fœetid, and its re-action was acid. There were multitudes of Bacteria and Vibriones, partly separate and partly aggregated (constituting the flocculi above mentioned). The separate Bacteria exhibited only very languid movements.

\section{No. XXI.-Neutral Turnip Infusion $+\frac{1}{2}$ gr. of Cheese,} showed a well-marked pellicle on its surface in twentyfour hours. In thirty-six hours the first pellicle had, in apparent change for six days, and then, instead of becoming filled with Bacteria, swarms only with Torula. Yet the infusion in this condition was perfectly capable of nourishing Bacteria, as I subsequently proved by inoculating it. Why then was it not inoculated by the living Bacteria, with which the air is thought by some to be teeming? 
great part, sunk to the bottom of the flask, though its place on the surface was already taken by a new, though thin, scum-like layer. After seventy-two hours, the flask was opened; there was no fotid odour of the fluid, and its re-action was still neutral. Examined microscopically the fluid showed an abundance of Bacteria, and also of short monilated filaments. There were, however, none of the ordinary kind of Vibriones, and no Leptotkrix. All the Bacteria exhibited very languid movements.

\section{Third Set of Experiments (XXII.-XXX.).}

a. Fliid exposed to Air in a Flask with a short Open Neck.

No. XXII.-Urine in twenty-four hours showed no change; though in forty-six hours the turbidity was well marked.* Examined microscopically it was found to contain an abundance of Bacteria.

b. Fluid in contact with Ordinary Air and its Particles; Neck of Flask Sealed after the Fluid had become Cold.

No. XXIII.-Urine in eighteen hours showed a distinct pellicle, though there was not much general turbidity. During the next few days the old pellicle fell to the bottom, and a new one formed.

c. Fluid in a Bent Neck Flask, having Eight acute Flexures.

No. XXIV.-Urine in forty-eight hours showed no change. After twelve days there was still no general turbidity,

* Some of the same fluid, exposed in a similar flask, without previous boiling, became turbid in eight hours, and lighter in colour; whilst, after twenty hours, the turbidity was extremely well-marked. 
though there was a slight flocculent deposit of an uncertain nature. Two days afterwards the flask was broken, when the odour of the fluid was still found to resemble that of fresh urine, and its re-action was acid. The flocculi were made up of granular aggregations, in the midst of which were a few bodies closely resembling Torula, though they were somewhat doubtful in nature. Neither Bacteria nor Vibriones could be found. The flask, having a short open neck, was then replaced in the warm bath. In sixteen hours the whole fluid had become turbid; it was also slightly fotid; and on microscopical examination it was found to be swarming with Bacteria, Vibriones, and Leptothrix.

No. XXV.-Turnip Infusion $+\frac{1}{2}$ gr. of Cheese in fortyeight hours showed no change, though in seventy-two hours there was a well-marked pellicle, in which some bubbles of gas were engaged. After ninety-six hours the neck of the flask was broken; the fluid was found to be fotid, and it had an acid re-action. On microscopical examination, a portion of the pellicle was seen to consist of multitudes of Bacteria, Vibriones, and jointed Leptothrix filaments.

No. XXVI.-Simple Turnip Infusion remained clear, and showed no appreciable change for seven days. On the eighth day a slight general turbidity of the fluid was noticed. On the ninth, the turbidity was rather more marked, though there was no trace of a pellicle; the neck of the flask having been broken, the fluid was found to be odourless and very faintly acid. On microscopical examination, multitudes of languid Bacteria of medium size were found, and also short monilated chains with 
from two to ten segments. There were no Vibriones, Leptothrix or Torula.*

e. Fluid (in vacuo) in a Flask, Sealed during Ebullition.

No. XXVII. - Healthy Urine after twenty-four hours showed no change. After eleven days there was still no apparent change, though on the thirteenth a slight amount of flocculent sediment was noticed. This deposit increased in amount, very slowly, during the next fortnight ; though afterwards the fluid seemed to undergo no further change, and did not become generally turbid. $\dagger$

No. XXVIII.-Healthy Urine $\left(\frac{1}{3}\right)$ and Filtered Turnip Infusion ( $\left(\frac{2}{3}\right)$ after forty-eight hours showed a very slight turbidity, which, however, became quite marked in another twenty-four hours.

No. XXIX.-Albuminous Urine $\left(\frac{1}{3}\right)$ and filtered Turnip Infusion ( $\left.\frac{2}{3}\right)$ after twenty-four hours, showed a slight turbidity, which became much more marked in forty-eight hours; whilst in seventy-two hours there was a considerable deposit at the bottom of the flask.

No. XXX.-Simple Turnip Infusion showed no change in forty-eight hours, though in seventy-two hours there was well-marked turbidity. The turbidity and sediment continued to increase for several days, and both were most marked on the tenth day, when the flask was opened. There was an outrush of gas, having an ex-

* The condition of the fluid, and the nature of its contents, were very similar to that met with in No. XXI.

$\dagger$ Still in my possession, unopened. In all probability the flocculi which formed would be found to be similar in their nicroscopical, as they certainly were in their naked-eye characters, to those met with in No. XXXV. 
tremely foetid odour. The fluid had an acid re-action, and when examined microscopically, multitudes of Bacteria, Vibriones and Leptothrix filaments were found - the movements of the Bacteria being very languid.

Fourth Set of Experments (XXXI.-XXXVII.).

b. Fluid in contact with ordinary Air and its Particles; Flask Sealed after the Fluid had become Cold.

No. XXXI.-Healthy Urine remained in the warm bath for twenty-eight days without undergoing the least change.

No. XXXII.-Simple Turnip Infusion remained in the warm bath for twenty-eight days without undergoing any appreciable change.* On breaking the neck of the flask, the fluid was found to be quite odourless. With its neck quite open, the flask was replaced in the waterbath. During the first forty-eight hours it underwent no apparent change, though at the end of seventy-two hours a slight general turbidity was noticeable, and an examination of a drop of the fluid (still odourless), showed a number of minute but very active Bacteria. $\dagger$

c. Fluid in a Bent-Neck Flask, having Eight acute Flexures.

No. XXXIII. - Simple Turnip Infusion showed no change after eight days' immersion in the warm bath.

* Experiment No. 8, recorded in 'Nature,' I870, No. 36, p. 194, may be compared with this and No. XXXIII.

† This experiment should be compared with Nos. XVIII. and XXXIII. It seems to show that if some fermentable fluids can be kept for a time under conditions in which they will not ferment, the constitution of the fluid, instead of remaining the same, undergoes a slow alteration by which it is rendered absolutely less fermentable, even when exposed to the most favouring influences. 
After eleven days, the fluid being still clear, the tube was broken just beyond the second bending from the bulb, and then the flask was re-immersed in the bath. After three days' exposure, the fluid being still clear, it was boiled in the flask for one minute, when it was noticed that the steam was quite odourless. The flask was then replaced in the water-bath, where it remained for twenty-two days (still with the neck open and broken just beyond its second bending) without showing any change.* It was then submitted to examination; the fluid was found to be devoid of all odour, it had a slightly bitter taste, and its re-action was very faintly acid. On microscopical examination no living things were found; there were no Bacteria, no Vibriones, and no Torula, only some mere granules, a small amount of amorphous matter, and a few fibres. $\dagger$

\section{No. XXXIV.-Turnip Infusion Neutralized by Am-}

* After this experiment had been completed, a fresh-filtered infusion of turnip was placed in the same flask (having the neck open just beyond its second bending), and after having been boiled for a few minutes it was immersed in the same water-bath. This fluid became turbid in thirty-six hours, and was then found to contain multitudes of Bacteria; and the characteristic odour of the turnip infusion was still appreciable.

$\dagger$ The results of this experiment are most interesting, especially if compared with what takes place when some of the same fluid is neutralized by ammonic carbonate (No. XXXIV.), with what occurs when a similar fluid (as in No. XXX.) is contained in a flask sealed during the continuance of ebullition, or also with what occurred in Nos. XIII. and XXXII. In the present case the second boiling seems to have destroyed what small amount of fermentability there was still remaining in the solution; but in No. IX. fermentation did take place after the second boiling-though this occurred only under the influence of diminished pressure and a higher temperature. 
monic Carbonate in forty-eight hours showed a slight turbidity, which slowly increased during the next two days. In two days more the turbidity was very great, and there was also a considerable amount of sediment. The fluid was then examined microscopically, and found to contain myriads of large but very languid Bacteria.

e. Fluid (in r'acuo) in a Flask which had been Sealed during Ebullition.

No. XXXV.-Healthy Urine underwent no apparent change for the first twelve days, then (the bulk of the fluid still remaining clear and bright) small greyish white flocculi began to collect at the bottom of the flask, which very slowly increased in quantity during the succeeding twelve days. At the expiration of this time the flocculi were pretty numerous, though the fluid was otherwise bright. The vacuum was ascertained to be still good, and on breaking the flask, the fluid was found to have a slightly acid re-action, though no appreciable odour. When examined microscopically, the flocculi were seen to be made up for the most part of mere granular aggregations (simple, and not in the form of Bacteria). Small Torula cells, however, existed in some quantity; also a few necklace-like chains, and a comparatively small number of Bacteria, some of which were tolerably active.

No. XXXVI.-Simple Turnip Infusion after twenty four hours showed no sign of change, though in thirtysix hours it was slightly turbid. On the fourth day the turbidity was well-marked and general, though there were no flake-like aggregations. When examined microscopically, the fluid was found to contain multitudes of Bacteria. 
No. XXXVII.-Turnip Infusion, ${ }^{*}$ Neutralized by Am. monic Carbonate in twenty-four hours was decidedly turbid. In thirty-six hours the turbidity was more marked, and there was a slight sediment. By the end of forty-eight hours both turbidity and sediment had notably increased. On the fourth day, there was a moderately clear fluid, containing an abundance of curdy or flake-like masses. When the flask was opened, these were found to be made up principally by the aggregation of myriads of Bacteria.

Fifth Set of Experiments (XXXVIII.-XLVII.). Fluids not boiled, but half-filling hermetically Sealed Flasks, containing Ordinary Air.

No. XXXVIII.-Turnip Infusion in ten hours showed a slight amount of turbidity. After forty-eight hours this was very well-marked : there was a thick pellicle on the surface, and, in addition, a small amount of deposit. On examination, the fluid and the pellicle were found to contain an abundance of Bacteria, Vibriones and Leptothrix filaments.

No. XXXIX.-Turnip Infusion $+\frac{1}{20}$ of Carbolic Acid after eight days showed no appreciable alteration in appearance, $\dagger$ no trace of pellicle or deposit. When examined microscopically, however, the fluid was found to contain some very minute Bacteria, though they were by no means abundant.

No. XL.-Hay Infusion had become quite turbid in twenty-four hours, and several shades lighter in colour.

* Some of same as that which was used (unaltered) in last experiment.

† It had been rendered turbid from the first, by the carbolic acid. 
After forty-eight hours the colour of the infusion was still lighter; there was more turbidity, and some sediment. On microscopical examination, the fluid was found to contain an abundarce of Bacteria, Tibriones and short Leptothrix filaments.

No. XII. - Hay Infusion $+\frac{1}{20}$ of Carbolic Acid showed no apparent change* after forty-eight hours, and when examined nicroscopically it revealed no trace of Bacteria, or other organisms. The neck of the flask was then again closed. On the twelfth day the fluid had still undergone no change in appearance, and when examined microscopically, it still showed no trace of organisms, though the fluid was-as it had been at the time of the first examination-full of minute, undissolved particles of carbolic acid.

Fluids boiled for five minutes, and half-filling hermetically Sealed Flasks containing Ordinary Air.

No. XLII.-Hay Infusion, after forty-eight hours, showed no change, and continued to remain quite clear and free from deposit until the twelfth day, when it was examined microscopically. No organisms of any kind could be detected.

No. XLIII.-Hay Infusion $+\frac{1}{20}$ part of Carbolic Acid showed no apparent changet for the first five days, though, on the sixth day, a slight deposit was noticed at the bottom of the flask. The deposit had increased, and was well-marked by the twelfth day,

* The fluid had been rendered paler and turbid from the first, by the addition of the carbolic acid.

$\dagger$ The alteration in colour was less marked than in the similar mixture which had not been boiled, though the turbidity was just as obvious. 
when, on microscopical examination, there were found amongst the granular flakes of the deposit, Torula of several varieties of size and shape. Many were spherical, others ovoid, or having an elongated oat-like shape: some were of the ordinary colour, and others were brownish in tint. The variety was most striking. No Bacteria were seen, though there were multitudes of active particles which seemed to differ from the minute spherules of undissolved carbolic acid.

Fluids (in vacuo)-boiled for five minutes, and Flasks Sealed during Ebullition.

No. XLIV.-Turnip Infusion, in seventy-two hours, showed a slight turbidity, which gradually increased. On the eighth day there was a considerable quantity of flake-like sediment, and some amount of general tur bidity. On the thirteenth day the vacuum was found to be still partly preserved. When the flask was opened the fluid was perceived to have a fœetid odour, and an acid re-action ; and, on microscopical examination, multitudes of Bacteria and Vibriones were seen. In the flake-like aggregations also (made up almost wholly of these organisms) there were a number of large thick-walled spores; some already formed, and others in process of formation by coalescence.

No. XLV.-Turnip Infusion $+\frac{1}{20}$ part of Carbolic Acid showed no increase of turbidity * for the thirteen days during which it was kept under observation. Before the flask was opened it was ascertained that the vacuum was well preserved. The odour of the fluid

This fluid was whitish, and somewhat opaque, from the first. 
was unaltered, and on microscopical examination no Bacteria, or other living things, were found.*

No. XLVI.-Hay Infusion, after forty-eight hours, showed no change, though, in seventy-two hours, there was perceptible a very small amount of a dirty greyish deposit. By the fifth day the deposit had slightly increased, and on the seventh day there was a trace of turbidity in the fluid. It did not undergo much further change, so that, on the twelfth day, the flask was opened. The vacuum was found to have been very slightly impaired; the odour of the fluid was almost natural, and its re-action was slightly acid. On microscopical examination of the deposit, Bacteria, Vibriones, short Leptothrix filaments, and Torule, were found, though not in very great abundance.

\section{No. XLVII.-Hay Infusion $+\frac{1}{20}$ part of Carbolic} Acid showed no apparent change for the first four days. On the fifth day there was a small quantity of powderlike sediment, and one dirty greyish-coloured flake. On the seventh day there were more small flakes at the bottom, and a slight general turbidity of the fluid. On the twelfth day, the turbidity and deposit having increased, the flask was opened-after it had been first ascertained that the vacuum had only been slightly impaired. The re-action of the fluid was still strongly acid. On microscopical examination of some of the deposit, there was found, amongst granular flakes and aggregations, a large number of Torulce cells, of most various shapes and sizes; also in the midst of the

* For other experiments showing a similar sterility, induced by a slight acidification with acetic acid, see 'Nature,' I870, No. 37, pp. 226 and 227. 
granule heaps many large, rounded or ovoidal, densely granular nucleated bodies, whose average size was $\frac{1}{1500} 1$ in diameter, though there were many of them much larger, and others even less than half this size. Intertwined amongst the granular matter also were a large number of algoid-looking filaments, $\frac{1}{20000}$ in diameter, containing segmented protoplasmic contents There were also in the fluid itself a number of mediumsize, unsegmented Bacteria, whose movements were somewhat languid.*

\section{Sixth Set of Experiments (XlViII.-LXV.).}

Ammoniacal Solutions, unboiled, and exposed to Ordinary Air in a Corked Bottle.t $\left(\right.$ Temp. $60^{\circ}-65^{\circ}$ F. $)$

No. XLVIII.-Ammonic Acetate Solution.-On the

* The results of this experiment, and of No. LXIII. are decidedly opposed to the reality of the germ-killing powers with which carbolic acid has been endowed by Professor Lister and others. I, however, had previously found that specimens of Torulce and Bacteria, obtained from freshly opened flasks, and then mounted as microscopical specimens in a mixture of glycerine and carbolic acid (in the proportion of $15: 1$ ), not unfrequently grew and multiplied under such conditions. MM. Béchamp and Estor, also found that Bacteria multiplied in carbolized fluids, and similar facts have been testified to by some Italian observers. But, organic fluids differ much from one another, so that the influence of carbolic acid may well be different upon different fluids. And, accordingly, we find that whilst its addition to, and subsequent boiling with, a hay infusion increases the fermentability of this, precisely the opposite effects are produced when the hay is replaced by a turnip infusion (see No. XLV.). Without wishing to undervalue in the least the system of treatment introduced, and so admirably carried out by Professor Lister, I am strongly of opinion that he explains his results by theories which are almost wholly incorrect.

$\dagger$ All the simple ammoniacal solutions were in the proportion 
tenth day the fluid was still quite clear, and free from sediment.

No. XLIX.-Ammonic Oxalate Solution.-On the tenth day there was no distinct opalescence of the fluid, but a well-marked whitish flocculent deposit. On microscopical examination no Bacteria were found in the fluid, and the deposit was made up by an aggregation of blackish and colourless granules, mixed with a few crystals and a very few Torula cells - all being held together by a sort of mucoid matrix. In the midst of this matter were found two or three very small, much branched, mycelial tufts of a fungus-growth.

J. L.-Ammonic Carbonate Solution.-On the tenth day the fluid showed a very faint opalescence, with a small amount of deposit, and a partial non-coherent scum on the surface, which, on microscopical examination, was found to be composed partly of amorphous granules, and partly of minute Bacteria, mixed with small necklace-like organisms. The fluid itself contained, in suspension, a few small and sluggish Bacteria, with a minute Torula cell here and there.

No. LI.-Ammonic Tartrate Solution after twentyfour hours showed the faintest opalescence of the fluid ; in forty-eight hours there was a bluish-white turbidity, and in seventy-two hours the turbidity was well marked. When examined microscopically the fluid was found to contain multitudes of very active Bacteria. On the thirteenth day the turbidity was not so well marked,

of ten grains of the salt to the fluid ounce of distilled water ; and to those which also contained sodic phosphate, three grains of this were added. About half an ounce of each solution was put into a one-ounce wide-mouthed bottle, and then tightly corked. 
though there was a very thin pellicle on the surface, and also the dirty-looking crumpled remains of another pellicle at the bottom, which, on examination, was found to be composed of an aggregation of Bacteria. The pellicle on the surface was very thin, and composed only of a single layer of Bacteria. In the fluid itself many Bacteria were seen, of medium size, and mostly sluggish in movement, though a few of them exhibited very active rotatory movements. No libriones, Leptothrix, or Torula, were found.

No. LII.-Ammonic Tartrate and Sodic Phosphate Solution after twenty-four hours showed the faintest opalescence; in forty-eight hours there was a bluishwhite turbidity, which, in seventy-two hours, had become more marked. When examined microscopically multitudes of Bacteria were found whose movements were very sluggish. On the thirteenth day there was a wellmarked whitish turbidity, due to Bacteria and Vibriones, a slight amount of deposit, and a firm pellicle which was found to be composed, almost wholly, of long unjointed Vibriones and unsegmented Leptothrix filaments, all of which, when separate, exhibited the most distinct eel-like movements, accompanied by an actual progression from place to place.

Ammoniacal Solutions, unboiled, and exposed to Air in a Corked Bottle, after Inoculation with a Drop of Fhiil containing living BaCteria and TORULÆ. (Temp. $60^{\circ}-65^{\circ} \mathrm{F}$.)

No. LIII-Ammonic Acetate Solution after twentyfour hours was faintly opalescent, and in forty-eight hours showed a very slight bluish tint. In seventy-two 
hours it was in the same state, and, on microscopical examination, the fluid showed no distinct Bacteria or other living things, though there were a number of very minute particles distributed, singly or in small groups, throughout the fluid. On the thirteenth day there was no change in appearance, except that the sediment had somewhat increased in amount. Still, no Bacteria could be found in the fluid or the sediment,only the above-mentioned particles, and a few somewhat larger, which resembled very minute Torula. Amongst the sediment, however, there were two or three very small mycelial tufts of a developing fungus.

No. LIV.-Ammonic Oxalate Solution.-On the eighth day the fluid showed a very faint opalescence, though there was a well-marked, greyish, flocculent deposit, which was found to be composed of an aggregation of colourless and blackish granules, of a multitude of minute crystalline particles (mostly diamond-shaped), and some rounded or ovoidal, thick-walled, spore-like bodies; amongst which, and enveloped in part by them, were several mycelial tufts of a fungus. A number of minute Bacteria were found distributed throughout the fluid, and also a quantity of minute star-like bodies (crystalline), about $\frac{1}{12000}$ in diameter.

No. LV.-Ammonic Carbonate Solution.-On the eighth day the fluid showed a very faint opalescence, and a slight deposit, which was found to be composed principally of amorphous granules. Distributed through the fluid were some small and sluggish Bacteria, though no other organisms were seen.

No. LVI.-Ammonic Tartrate Solution.-After twentyfour hours the fluid showed the faintest opalescence, 
and in forty-eight hours there was a slight bluish-white turbidity. In seventy-two hours the turbidity was well marked, and there was a very thin pellicle on the surface. When examined microscopically the fluid was. found to contain multitudes of very active Bacteria, and the pellicle was also composed of an aggregation of Bacteria. On the thirteenth day the opacity had somewhat increased; there was also a well-marked pellicle, and an obvious deposit. The pellicle was found to be composed of Bacteria, and in the fluid there were multitudes of medium-size Bacteria and Vibriones, with here and there a small Torula cell.*

* On comparing the corresponding experiments of series XLVIII.-LI. with those of series LIII.-LVI. less difference is found than might have been expected by many. The comparison of the numbers of each series with one another, also reveals the interesting fact, that the mere presence of $\mathrm{N}, \mathrm{C}, \mathrm{O}$, and $\mathrm{H}$, is not all that is required, even for the growth and nutrition of the lower living things. These elements seem to lapse into the new combinations constituting living matter of various kinds, more easily from certain pre-existing states of combination than from others. Solutions of ammonic tartrate are much more favourable starting points for the new combinations than solutions of ammonic acetate. The comparison of experiment No. LI. with No. LII. is extremely interesting in reference to the dogma that phosphorus is a necessary ingredient in living matter. Solutions of the ammonic tartrate in distilled water have been twice analyzed for me by a skilled chemist, without revealing the least trace either of phosphorus or sulphur. This result is very remarkable when compared with the amount of living matter which may so soon appear in such a solution: the number of the organisms and the rapidity of their evolution, being almost equal to that which occurs in a similar solution to which a phosphate has been added. However much, therefore, phosphorus may aid the development of organisms in many fluids, there is still an important difference between many and all, 
Ammoniacal Solutions (in vacuo) in Flasks which were hermetically Sealed during Ebullition of their Fluids at a Temperature of $90 F_{0}^{\circ *}$ (Subsequently exposed in waterbath to a Temperature of $75^{\circ}-85^{\circ} \mathrm{F}$.).

No. LVII.-Ammonic Tartrate Solution after sixty hours showed a slight sediment, with bluish flakes attached to sides of flask. In eighty-four hours there was a general bluish opalescence, and on microscopical examination the fluid was found to contain multitudes of Bacteria.

No. LVIII.-Ammonic Tartrate and Sodic Phosphate Solution.-After sixty hours there was a slight general bluish opalescence. In eighty-four hours the general opalescence was not more marked, but there were many flake-like aggregations in the fluid, which on

which if more frequently borne in mind, would render universal propositions more scarce (see 'Journal of Chenical Society,' March, I87 I, pp. 72-74). The truth of the dictun "Ohne Phosphor gar kein Leben," is, I venture to think, far from being proved. If on insufficient evidence (referring only to particular fluids) such a dictum is arrived at ; and if then, the presence of organisms in any fluid is to be taken as evidence of the existence of phosphorus (even though this cannot be otherwise substantiated), the case of phosphorus in relation to Life comes to be similar to the case of the much abused germs.

Mutato nomine, de te

\section{Fabula narratur.}

* The fluids were boiled at the low temperature, with the aid of an air-pump, merely in order to be able to procure a more perfect vacuun in the flasks; these experiments being destined to show whether the simple (uninoculated) solutions would become turbid in vacuo-that is to say, without the oxidizing influence of the air-when they had not been exposed to an amount of heat sufficient to destroy any living or dead ferments which they might contain. 
microscopical examination were found to be aggregations of Bacteria.

Ammoniacal Solutions boiled (at $212^{\circ} F$.), and exposed to Air in Flasks whose Open Necks were only loosely coz'ered with Paper Caps: subsequent Inoculation. (Temp. $75^{\circ}-85^{\circ}$ F.).

No. LIX.-Ammonic Tartrate Solution.-The fluid remained quite clear, and free from all trace of turbidity up to the ninth day, when it was inoculated with some living Bacteria. In fifty hours after the inoculation there was a very faint opalescence of the fluid, which, in another 24 hours, had become much more marked. On microscopical examination it was found to contain multitudes of Batteria.

No. LX.-Ammonic Tartrate and Sodic Phosphate Solution.-After four days the fluid was still quite clear. In seven days no trace of general turbidity, though there was a minute dirty-grey aggregation about ${ }_{14}^{1}$ " in diameter at the bottom of the flask. On the sixteenth day the grey aggregation had very slightly increased in size, though the fluid above was still perfectly clear. The grey mass was removed by a small pipette, and, on microscopical examination, it was found to be composed of an aggregation of minute extraneous fibres, mixed with blackish particles and amorphous granular matter, in which were growing many Torulacells in all stages of development, and also a minute mycelium composed of branched Leptothrix-like fibres."

- A deposit of this kind is almost invariably found in such solutions after their fermentability has been lowered by previous boiling. Growth takes place very slowly in these cases, and also when similar boiled fluids are contained in vacuo. 
The clear fluid was then inoculated with some living Bacteria, and the bulb of the flask was replaced in the warm bath. After fifty hours the solution showed a bluish turbidity, which, in thirty-six hours more, had increased to a well-marked whitish opacity, and when examined, the fluid was found to be swarming with active Bacteria.

Solutions of Ammonic Tartrate and Sodic Phosphate were heated, in their respective Flasks, for Fifteen Minutes to the Temperatures mentioned below. The Necks of the Flasks were afterwards loosely covered with Paper Caps, whilst the Bulbs were immersed in a Water-Bath kept at a Temperature of $75^{\circ}-85^{\circ} \mathrm{F}$.

No. LXI.-Solution heated to $149^{\circ} \mathrm{F}$.

No. LXII.

No. LXIII.

No. LXV.
No. LXIV.

$\begin{array}{lll}, & \quad, & \text { I } 58^{\circ} \mathrm{F} . \\ , & , & \text { I } 58^{\circ} \mathrm{F} . \\ , & \quad, & \text { I } 67^{\circ} \mathrm{F} . \\ & \quad & \text { I } 67^{\circ} \mathrm{F} .\end{array}$

All these solutions remained quite clear and free from any trace of general turbidity for ten days. Each fluid was then inoculated with some living Bacteria, and in the space of thirty-six to seventy-two hours, all had become more or less obviously turbid, and on microscopical examination this turbidity was found in each case to be almost wholly due to the presence of multitudes of Bacteria.

Interpretation of the Experiments: Conclusions as to the Cause of Fermentation, and as to the Occurrence of Archebiosis.

These experiments seem to show quite conclusively that M. Pasteur's explanations are altogether inade- 
quate to account for the occasional preservation of boiled fluids in bent-neck flasks. They show that the preservation, far from being universal, is only occasional, and that preservation or non-preservation of different fluids is almost wholly dependent upon their nature. They lend no countenance, moreover, to his particular theory, that fermentation cannot be initiated without the agency of living ferments,- - they are, on the contrary, wholly opposed to this restriction.

The plug of cotton-wool, or the narrow and bent tube may, it is true, protect the boiled fluid from subsequent contact with living "germs"; but that the fluids do not undergo change on account of such deprivation cannot be safely affirmed, when the same means would also filter from the fluid some of the multitudinous particles of organic matter (dead), which the air undoubtedly contains, and which may act as ferments. It must be remembered that the main object of M. Pasteur's investigation was to determine whether fermentation took place under the agency of mere dead nitrogenous matter, as Liebig and others affirm; or whether it is only initiated by living organisms, as he himself supposes. Obviously, therefore, the same filtration which purified the air from any living organisms would filter from it its nitrogenous particles, which are the other possible ferments: so that no conclusion could be drawn from such experiments, more favourable to the one than to the other of these hypotheses. All that 
could have been safely affirmed was, that by boiling the fluid, and then protecting it from subsequent contact with everything that could act as a ferment, fermentation would not take place.

Even this however,-as the preceding experiments fully show-cannot be truly affirmed to be a general rule. Some infusions do undergo change, notwithstanding this treatment and deprivation, whilst others do not: that is to say, some still preserve a first degree of fermentability even after boiling, whilst others are reduced by this process to the second degree of fermentability. These latter are unable to initiate changes by virtue of their own inherent instability; molecular re-arrangements require to be set on foot in them by contact with some more unstable substance, which is itself undergoing change.

That such is the correct explanation of the reason why some fluids do not ferment in bent-neck flasks, seems obvious from the discordant results obtained in many other experiments, after the free admission of uncalcined air to the fluids which had been boiled. The fluids were deprived of their virtues in some cases by the heat to which they had been subjected, so that whether they underwent change or not, may have depended upon the accidental presence or absence, in the air which was subsequently admitted to the fluid, of some unheated organic fragments, capable of initiating fermentative changes. If germs were as omnipresent as they have been represented to 
be, such fluids ought always to have undergone fermentation.

Whilst I have found that any given fluid, whose strength is about equal on different occasions, acts in a definite manner when the flask is hermetically sealed after expulsion of all its air and during the continuance of ebullition; and, whilst a like definite result can generally be obtained, when calcined air is admitted to the boiled fluid before the vessel is hermetically sealed; it is found, on the other hand, that the result is in no way predicable when uncalcined air is admitted. Sometimes fermentation takes place, and sometimes in other flasks-sealed at the same time, and subsequently placed under the same conditions - no change whatever occurs. My own experience in this respect accords perfectly with that of M. Pasteur.* He, however, at once came to the conclusion that the only inference from such facts was that "germs" are not so universally distributed as they had been supposed to be by Bonnet and Spallanzani. $\dagger$ The unprejudiced inquirer, however, will perceive that M. Pasteur was entitled to come to no such conclusion concerning germs which was not equally applicable to minute fragments or débris of organic matter floating in the air. And, similarly, the evidence which he adduces with regard to the diminution in the number of the fertile flasks when they were filled with some of the still air of the caves

* Loc. cit. p. 7 I. $\dagger$ Loc. cit. pp. 75 and 76. 
of the observatory, or else with some from the peaks of the Jura,* far away from the haunts of men, had no bearing upon the distribution of germs which was not equally applicable to that of dead organic particles. Such evidence, therefore, was valueless for settling between the rival doctrines of fermentation-it could not possibly help us to decide whether living or dead ferments were necessary. Dead organic particles would sink in still air in the same manner as living organisms; $\dagger$ and similarly, dead organic particles, have been shown to be less and less numerous in the atmosphere in proportion to the elevation obtained. $\ddagger$ In these latter experiments M. Pasteur made use of yeast-water (alone or sweetened), and of urine-all three of them fluids, which, after having been boiled, are apt to possess only the second degree of fermentability. Shortly afterwards, M. Pouchet, in concert with MM. Joly and Musset, § repeated these experiments, with the sole difference that they employed strong infusions of hay-which experiment has shown almost invariably to possess the first degree of fermentability. And seeing that all their flasks, after a time, yielded organisms from whatever mountain elevation

* Loc. cit. pp. 83 and 84 .

$\dagger$ The subsidence of the atmospheric particles has been ably' demonstrated by Professor Tyndall.-See 'Nature,' I 870.

¥ See M. Pouchet's 'Nouvelles Expériences sur la Génération Spontanée,' \&c., p. 69.

$\S$ See various communications in 'Compt. Rend.' (1863), t. LVII. 
the air had been taken-the combined evidence tends strongly against the view of M. Pasteur. Since the germs in the fluids and in the flasks, in each set of experiments, had been previously destroyed by ebullition, and since in each set, also, air of the same character had been admitted to the boiled fluids, the different results seemed to show that fermentation or non-fermentation, in such cases, depends wholly upon the quality of the fluids employed.

Other evidence which is so much vaunted by $\mathrm{M}$. Pasteur and his supporters, as to the possibility of inducing fertility in previously sterile flasks, by the addition of a portion of asbestos containing the solid particles filtered from the atmosphere, ${ }^{*}$ is also equally valueless for confirming the proposition that fermentation is only capable of being initiated by living ferments. The same asbestos which may contain living spores or organisms ("germs"), does undoubtedly contain many decomposable particles and fragments of organic matter. $\dagger$ The previously barren solution may therefore be rendered fertile by the

* Loc. cit., p. 40.

$\dagger$ Speaking of experiments in closed flasks, in which the air has been either calcined or filtered, Gerhardt ("Chimie Organique,' t. IV. p. 545) says :- "Si dans les premières expériences l'air calciné ou tamisé s'est montré beaucoup moins actif que l'air non soumis à ce traitement, c'est que la chaleur rouge ou le tamisage enlève à l'air non seulement les germes des infusoires et des moisissures, mais encore les débris des matières en décomposition qui y sont suspendues, c'est-à-dire les ferments dont l'activité viendrait s'ajouter à celle de l'oxygène de l'air." 
mere addition of those portions of unstable organic matter, whose molecular mobility has not been impaired by the agency of heat, and which are therefore capable of initiating fermentations. This view is strengthened, as M. Pouchet has pointed out, by the fact that in these cases, instead of meeting some of the various kinds of organisms which are supposed to have representatives in the air, and whose spores or ova may be supposed to have been sown, it is often merely Bacteria which are encountered,-differing in no respect from those that may present themselves in a somewhat similar infusion, which has undergone change in a closed flask without any such hypothetical sowing of living spores or germs. It is more especially important to bear in mind this consideration, when portions of organic matter can always be easily demonstrated amongst such atmospheric dust; whilst living Bacteria, or other organisms, such as are first produced as a result of the supposed sowing of spores, either cannot be demonstrated, or would seem, from other evidence, to be at least very sparingly distributed.*

The fact revealed by M. Pasteur, that some fluids remain unchanged for an indefinite period, after having been boiled in flasks, with long and bent necks, is easily explicable in accordance with the physical theory of fermentation, and now that it has been thoroughly proved that other fluids-submitted to pre-

* On what other supposition can one explain the results of experiments LVII.-LXV., and of others alluded to on p. 100? 
cisely similar conditions - do nevertheless undergo fermentation, this fresh fact is just as completely adverse to the explanations and views of M. Pasteur, as it is thoroughly harmonious with the doctrines of Baron Liebig. The fluids which are capable of being preserved-generally not presenting a high degree of fermentability - do not undergo change, at ordinary atmospheric pressure, after having been boiled, unless they are brought into contact either with some preexisting living things or with some unaltered organic particles from the atmosphere. Neither of these, however, can gain access to the fluid, in such a vessel; because all the air which enters, after the first inrush into the still almost boiling fluid, has to pass, more or less slowly, through the numerous flexures of the narrow neck of the flask and the two or three strata of fluid which always remain therein.

Some of the fluids which do not undergo change in these bent-neck vessels are, however, by no means notable for possessing a low degree of fermentability. This is the case, for instance, with infusions of turnip, which, under other conditions, have been found to be most prone to undergo fermentation. And, I have found in several cases in which such an infusion had been exposed in a bent-neck vessel, and had remained unchanged for twelve or fourteen days (even though subjected to a temperature of $85^{\circ}-95^{\circ} \mathrm{F}$.), that if the neck of the flask were then broken shortly above the bulb, the solution would still continue without 
alteration for a week, ten days, a fortnight, or even more-although freely exposed to the air, and therefore to the access of any living germs which might be floating about in the atmosphere.

The views hitherto expressed with reference to the causes of fermentation and putrefaction, and to the interpretations which M. Pasteur's experiments are capable of receiving, seem to derive all the additional support that can be needed, from the results of my own experiments with boiled fluids, in sealed flasks, from which all air had been expelled.

Some of the same fluid being taken and divided into three parts, each portion is placed in a separate flask, in which it is boiled for a period of ten minutes. One of the flasks (A) is provided with a long and bent neck, so that the air which re-enters is deprived of its germs and organic particles; another (B) has only

* See notes on pp. 73 and 79. It was not that these fluids were incapable of being inoculated, or that they were unsuitable for the development of the lower forms of life, as was shown by their subsequent fate, and by the fact that they can always speedily be made to become turbid if they are really inoculated with living Bacteria. Almost similar facts in opposition to the prevalent Panspermic views have been noted by Professor Cantoni (Rend. del R. Istit. Lombardo, Novembre, I869). He found (as I have also frequently found) that when fluids had been subjected to the influence of high temperatures, and had subsequently remained sterile in closed flasks, they might be freely exposed to the air for one or two weeks, or more, without becoming turbid-although at any time a general turbidity could be speedily induced, by introducing a few living Bacteria into the fluid. 
a short neck, and to this, the access of germs and organic particles is freely permitted till the fluid has become cool, and then the neck of the flask is hermetically sealed; whilst the last (C) is sealed during ebullition, after all air has been expelled. Now, if Pasteur's theory of fermentation, and the prevalent notions concerning the universal distribution of "germs" throughout the atmosphere were true, it might be expected that the fluid in B would always rapidly change; that that in $\mathrm{A}$ would always remain pure; and that the fluid in C would, similarly, undergo no alteration. The facts, however, are quite the reverse : if a strong turnip infusion be employed, the fluid in $\mathrm{A}$ will almost always remain unchanged; that in B will sometimes rapidly change, and at other times will remain quite pure; whilst that in $\mathrm{C}$ will almost invariably become turbid in from two to six days. But, even if it were not the case that some fluids, different from those used by M. Pasteur, will almost invariably undergo change in bent-neck vessels, M. Pasteur's explanation of the cause of the preservation would have been altogether upset by the fact that some of the very fluids which remain pure in the bentneck apparatus will become fatid if shut up in vacuo. It is, therefore, of course useless to talk of a particular boiled fluid having been saved from putrefaction on the ground that the living atmospheric germs (whose presence is supposed to be necessary for the initiation of such a process) have been altogether filtered from 
the re-entering air, when some of the same fluid will putrefy, if placed under different conditions by which it is freed both from the influence of the atmosphere and from its germs-i.e., when, instead of filtering the re-entering air, no air is permitted to enter. Germs and atmospheric particles being equally got rid of in both sets of cases, the great difference between them is that the weight of the atmosphere is also got rid of in my experiments - the fluids being contained in vacuo. Now it has been ascertained by Mr. Sorby, that pressure undoubtedly influences "chemical changes taking place slowly, and therefore, probably due to weak or nearly counterbalanced affinities;" and he also states, in the Bakerian Lecture for $1863,{ }^{*}$ that "a considerable number of facts have been described, showing that pressure will more or less influence such chemical actions as are accompanied by an evolution of gas, so that it may cause a compound to be permanent, which otherwise would be decomposed." If increase of pressure retards, a diminution of pressure will facilitate such chemical changes, so that one can only explain the results which I have obtained, on the ground that many boiled fluids, which will not undergo change when protected from the influence of atmospheric particles (living or not living) at the same time that they are subjected to ordinary or increased pressure,

* ' On the Direct Correlation of Mechanical and Chemical Forces.'-Proceedings of the Royal Society, vol. xii. pp. 539 and 546. 
will, on the contrary, pass through such changes when pressure is removed, and the fluids are preserved in vacuo. It is not pretended that this is a rule applicable to all organic fluids-far from it. Diminution of pressure does seem, however, to be a very potential cause of change in some fluids. The extent to which changes of a fermentative character can progress in the absence of atmospheric oxygen, is also evidently subject to much variation, in accordance with the nature of the dissolved fermentable substances.

These facts are not so new and exceptional, however, as they may at first sight appear. It has been long known that a boiled fluid extremely prone to change, will not yield infusoria if the vessel in which it is contained is filled with the fluid. Burdach says* :"Gruithuisen a reconnu que des infusions, même très fécondes d'ailleurs, celles du foin par exemple, ne donnaient point d'infusoires dans des flacons de verre dont le bouchon était assez enfoncé pour toucher à la surface de l'eau." On the other hand, no experiments with which I am acquainted, in which heated fluids and calcined air have been shut up in closed flasks, have yielded so many positive results as those of Professor Wyman of Cambridge, U.S.,-and his were performed under precisely the reverse conditions. Large flasks were used, and only $\frac{1}{15}-\frac{1}{20}$ of their bulk

* 'Traité de Physiologie.' Translated by Jourdan. I 837. t. i., p. I8. 
was filled by the experimental fluids.* Gruithuisen's results were explained by Burdach on the ground that a certain amount of air was necessary, and it was also with the view of subjecting his fluids to as large an amount of air (calcined) as possible, that Professor Wyman employed small quantities of fluids in large flasks. These views were dictated by the chemical doctrines of Gay-Lussac and others, to the effect that the oxygen of the air is the initiator or primum movens of fermentative changes. $\dagger$

Now, without doubting in the least that in some instances this may be the case, it seems to me quite obvious, from my own experiments, that a different interpretation may be given of Gruithuisen's resultswhich I' have myself verified,-and of the fact that meats and vegetables will often remain unchanged for years after having been heated in closed tins from which all air has been expelled.t

If we ponder only upon the fact that certain fluids, in contact with a very small quantity of air, in an hermetically-closed vessel, will not undergo change; though these same fluids will change when exposed

* 'American Journal of Science,' July, I862.

$\dagger$ See Gerhardt's, 'Chimie Organique,' t. iv. pp. 540 and 547.

$\ddagger$ It was, indeed, the consideration of these latter facts which originally forced Gay-Lussac to the conclusion, that fermentation would not take place in vacuo, or without the presence of free oxygen, which was and still is, believed by many, to be the immediate determining cause of fermentation. 
to a much larger quantity of calcined air, there may be strong reason for coming to an opinion similar to that of Gay-Lussac. When, however, it is also ascertained that provisions which have been subjected to the long-continued influence of heat, do not undergo change in closed vessels, if all air has been expelled from the very small space above the level of the provisions; though many organic infusions will putrefy if they occupy only one half, or less, of a hermetically closed vessel from which all air has been similarly expelled by ebullition of its fluid contents, it is impossible that the same explanation can hold good. And at the same time another interpretation is suggested for the first set of facts.

The last-mentioned experiments prove* that fermentation can take place in vacuo, when the conditions are more favourable than those which present themselves within the almost full tins containing provisions. The change in these latter cases cannot (in the great majority of instances) proceed far $\dagger$, because there is no adequate space into which

* This proof is more severe in certain other experiments (not yet published) in which I had the benefit of Professor Frankland's assistance. The vacuum in these cases was perhaps more perfect, having been procured by means of a Sprengel's pump and a simultaneous ebullition of the fluid, during which the flasks were hermetically sealed. The closed flasks were subsequently exposed to a temperature of $293^{\circ} \mathrm{F}$. for a short time.

$\dagger$ An examination of tins of "perfectly good" meats has convinced me that a very small number of Bacteria and Leptothrix filaments are occasionally to be met with. 
residual gases may be emitted. When this emission (which is almost always one of the accompaniments of a fermentative change) has taken place to a slight extent, the meats are in the very best condition for preservation. There is an utter absence of light, an absence of free oxygen, and also an absence of that diminished pressure which my experiments seem to show is favourable to the promotion of many kinds of fermentative change. So that if fermentation does not take place in a closed flask which is full of a boiled infusion of hay,* it may be owing to the fact that there is no space for the residual gases, and that undue pressure retards many fermentative changes. This is also perfectly compatible with the other fact that the same kind of fluid will undergo change when a small quantity of it is contained in a comparatively large flask-owing to there being, in such a case, plenty of room for residual gases to be effused, before that undue amount of pressure is brought about, in the presence of which such a fluid will no longer ferment or putrefy. Fluids, therefore, whose putre-

* It has, however, been ascertained by M. Pouchet, that beeryeast, even after prolonged ebullition, will undergo change in a flask which is full and hermetically sealed : and the manufacturers of preserved meats also find that occasionally, in some of their best prepared tins, the meats become putrid, and that the putridity is accompanied by the presence of organisms. Some fermentations are doubtless attended by a less copious emission of waste gases than that which characterizes other fermentations; and some fermentations will progress in spite of a moderate amount of pressure. 
faction is hindered by increased pressure and favoured by diminution of pressure, may be placed under conditions which are successively more favourable than the last, by putting a gradually smaller and smaller quantity of fluid into a flask, to which calcined air is admitted, and, better still-if the stimulus of oxygen is not absolutely needed in order to incite fermentation in the fluid employed-by only half filling the flask, and procuring a more and more perfect vacuum.

In accordance with the doctrines of Baron Liebig, therefore, my experiments, as well as those of many other investigators, tend to show that fermentative and putrefactive changes are merely processes of chemical re-arrangement, which frequently take place-as it were "spontaneously" - owing to the inherent instability of certain nitrogenous compounds in the presence of free oxygen. My experiments have, however, also revealed the additional fact that, under the combined influence of heat and diminished pressure, some fluids will undergo fermentation even in closed vessels, from which all air has been expelled. They lend no support to the idea that the air is so thickly laden with living germs as some would have us suppose; and in view of the mass of positive information now in our possession concerning the degree of heat which suffices to kill the lowest organisms, they also, as I think, entitle us to come to the conclusion that such organisms are (as the microscopical evidence might lead us 
to believe) really capable of being evolved de novo. These lowest organisms are, in fact, to be regarded as occasional concomitant products, rather than as invariable or necessary causes of all fermentative changes.

It would thus appear that specks of living matter may be born in suitable fluids, just as specks of crystalline matter may arise in other fluids. Both processes are really alike inexplicable-both products are similarly the results of the operation of inscrutable natural laws, and what seem to be inherent molecular affinities. The properties of living matter, just as much as the properties of crystalline matter, are dependent upon the number, kind, and mode of collocation of the atoms and molecules entering into its composition. There is no more reason for a belief in the existence of a special "vital force," than there is for a similar belief in the existence of a special "crystalline force." The ultimate elements of living matter are in all probability highly complex, whilst those of crystalline matter are comparatively simple. Living matter develops into Organisms of different kinds, whilst crystalline matter grows into Crystals of diverse shapes. The greater modifiability of living matter, and the reproductive property by which it is essentially distinguished from crystalline matter, seem both alike referable to the great molecular complexity and mobility of the former. Crystals are statical, whilst 
organisms are dynamical aggregates, though the evolution of both, marked by their peculiar characteristics, may be regarded as visible expressions testifying to the existence of one all-pervading Power

"Whose dwelling is the light of setting suns, And the round ocean, and the living air, And the blue sky, and in the mind of man :

A motion and a spirit that impels All thinking things, all objects of all thought, And rolls through all things." 


\section{LONDON :}

PRINTED BY WILLIAM CLOWES AND SONS, STAMFORE STREET, AND CHARING CROSS. 
Second Edition, revised and corrected, crown Svo., price $8 s .6 d$.

\section{MR. A. R. WALLACE'S CONTRIBUTIONS TO THE} THEORY OF NATURAL SELECTION. A Series of Essays.

" He has combined an abundance of fresh and original facts, with a liveliness and sagacity of reasoning which are not often displayed so effectively on so small a scale."-Saturday Review.

" Whatever may be the opinions of readers with regard to this strangely fascinating volume, there can be no doubt of its value in explaining and connecting a variety of facts in natural history, which are too generally regarded as inexplicable anomalies."-Examiner.

Recently published, in crown 8vo. price $9 s$.

\section{ON THE GENESIS OF SPECIES. By ST. GEORGE} MIVART, F.R.S. With numerous Illustrations.

" In no Work in the English language has this great controversy been treated at once with the same broad and vigorous grasp of facts, and the same liberal and candid temper."-Saturday Reviezw.

"Mr. Mivart's great knowledge, and temperate though forcible language, combine to render his views as to the bearings of science on theology and morality, deserving of the most attentive perusal." Spectator.

HEREDITARY GENIUS: An Inquiry into its Laws and Consequences. By FRANCIS GALTON, F.R.S. 8vo. i2s.

Mr. Darwin, in his 'Descent of Man,' says :- “We know, through the admirable labours of Mr. Galton, that genius, which implies a wonderfully complex combination of high faculties, tends to be inherited."

ON COMPARATIVE LONGEVITY IN MAN AND THE LOWER ANIMALS. By E. RAY LANKESTER, B.A. Crown 8vo. 4 s. $6 d$.

\section{LONDON: MACMILLAN AND CO.}


New and Cheaper Edition, crown 8vo. $7 s .6 d$.

PROF. HUXLEY'S LAY SERMONS, ADDRESSES, AND REVIEWS.

Contents :-Emancipation, Black and White-A Liberal Education - Scientific Education - Study of Zoology - The Physical Basis of Life-Scientific Aspects of Positivism-On a Piece of Chalk-The Origin of Species, \&c.

[This Day.

ESSAYS SELECTED FROM PROFESSOR HUXLEY'S LAY SERMONS, ADDRESSES, AND REVIEWS. Crown Svo. $2 s$.

MR. A. R. WALLACE'S 'MALAY ARCHIPELAGO.' The Land of the Orang-Utan and the Bird of Paradise. A Narrative of Travel, with Studies of Man and Nature. 2 vols. crown 8 vo. with 9 Maps and upwards of 50 Illustrations, price $24 s$.

[Second Edition.

HABIT AND INTELLIGENCE, IN THEIR CONNECTION WITH THE LAWS OF MATTER AND FORCE. A Series of Scientific Essays. By JOSEPH JOHN MURPHY. Two vols. 8vo. I6s.

FORCE AND NATURE. ATTRACTION AND REPULSION. The Radical Principles of Energy graphically discussed in their Relations to Physical and Morphological Development. By C. F. WINSLOW, M.D. Svo. I4s.

A PHYSICIAN'S PROBLEMS. By CHARLES ELAM, M.D., M.R.C.P.

Contents:-Natural Heritage-On Degenerations in Man-On Moral and Criminal Epidemics-Body \%. Mind-Illusions and Hallucinations-On Somnambulism-Reverie and Abstraction. Crown Svo. price $9 s$.

LONDON: MACMILLAN AND CO. 
Bedford Street, Covent Garden, London. April, ISiI.

Macmillan \& Co.'s General Catalogue of Works in the Departments of History', Biography, Travels, Poetry, and Belles Lettres. With some short Account or Critical Notice concerning cach Book.

\section{SECTION I.}

\section{HISTORY, BIOGRAPHY, and TRAVELS.}

\section{Baker (Sir Samuel W.).-THE NILE TRIBUTARIES OF} ABYSSINIA, and the Sword Hunters of the Hamran Arabs. By Sir Samuel W. Baker, M.A., F.R.G.S. With Maps and Illustrations. Fourth and Cheaper Edition. Crown 8vo. 6s.

Sir Samnel Baker here describes twelve months' exploration, during which he examined the rivers that are tributary to the Nile from Abyssinut, including the Atbara, Settite, Royan, Salaan, Angrab, Rahad, Dinder, and the Blue Nile. The interest attached to these portions of African differs entirely from that of the IVhite Nile regions, as the whole of Upper Egypt and Abyssinia is capable of deveiopment, and is inhabited by races having some degree of civilization; while Central Africa is peopled by a race of savages, whose future is more problematical.

THE ALBERT N'YANZA Great Basin of the Nile, and Exploration of the Nile Sources. New and Cheaper Edition, with Portraits, Maps, and Illustrations. Two vols. crown Svo. I6s.

"Bruce won the source of the Blue Nile; Speke and Grant won the Victoria source of the great White Nile; and I have been permitted to $\frac{\text { A. } 2 .}{10.000 \cdot 4 \cdot 7 \text { I. }}$ 


\section{Baker (Sir Samuel W.) (continued)-}

succed in completing the Nile Sources by the discovery of the great reservoir of the equatorial waters, the Albert N'y'anza, from which the river issues as the entire White Nile."-PREFACE.

NEW AND CHEAP EDITION OF THE ALBERT N'YANZA. I vol. crown Svo. With Maps and Illustrations. 7 s. $6 d$.

Barker (Lady).-STATION LIFE IN NEW ZEALAND. By Lady Barker. Second and Cheaper Edition. Globe Svo. 3s. $6 d$.

"These letters are the exact account of a lady's expernence of the brighter and less practical side of colonization. They record the expeditions, adventures, and emergencies diversifying the daily life of the wife of a New Zealand shcep-farmer; and, as each was written while the novelty and excitement of the scenes it describes were fresh upon her, they may succeed in giving here in England an adequate impression of the delight and freedom of an existence so far removed from our own highly-zurought civilization."-PREFACE.

"We have never read a more truthful or a pleasanter little book."

ATHENæUM.

\section{Baxter (R. Dudley, M.A.).-THE TAXATION OF THE UNited Kingdom. By R. Dudley Baxter, M.A. Svo. cloth, $4 s .6 d$.}

The First Part of this zuork, originally read before the Statistical Society of London, deals with the Amount of Taxation; the Second Part, which now constitutes the main portion of the work, is almost entirely nerv, and embraces the important questions of Rating, of the relative Taxation of Land, Personalty, and Industry, and of the direct effect of Taxes upon Prices. The author trusts that the body of facts here collected may be of permanent value as a record of the past progress and present condition of the population of the United Kingdom, independently of the transitory circumstances of its present Taxation.

NATIONAL INCOME. With Coloured Diagrams. Svo. 3 s. $6 d$.

PART I.-Classification of the Population, Upper, Middle, and Labour Classes. II.-Income of the United Kingdom.

A painstaking and certainly most interesting inquiry." - PALL MALL GazetTe. 
Bernard.-FOUR LECTURES ON SUBJECTS CONNECTED With DiplomaCy. By Mountague Bernard, M.A., Chichele Professor of International Law and Diplomacy, Oxford. 8vo. 9 s.

Four Lectures, dealing with (I) The Congress of Westphaliu; (2) Systems of Policy; (3) Diplomacy, Past and Present; (4) The Obligations of Treaties.

Blake.-THE LIFE OF WILLIAM BLAKE, THE ARTIST. By Alexander Gilchrist. With numerous Illustrations from Blake's designs, and Fac-similes of his studies of the "Book of Job." Medium 8 ro. half morocco, ISs.

These volumes contain a Life of Blake; Selections from his Writings, including Poems; Letters; Annotated Catalogue of Pictures and Drazuings, List, with occasional notes, of Blake's Engravings and Writings. There are appended Engraved Designs by Bluke; (I) The Book of Job, twentyone photo-lithographs from the originals; (2) Songs of Innocence and Experience, sixteen of the original Plates.

\section{Blanford (W. T.).-GEOLOGY AND ZOOLOGY OF ABISSINIA. By W. T. BLANFord. Svo. $21 s$.}

This work contains an account of the Geological and Zcological Observations made by the Author in Abyssinia, when accompanying the British Army on its march to Magdala and back in $\mathrm{I} 868$, and during a short journey in Northern Abyssinia, after the defarture of the troops. Part I. Personal Narrative; Part II. Geology; Part III. Zoology. With Coloured Illustrations and Geological Map.

\section{Bright (John, M.P.).-SPEECHES ON QUESTIONS OF}

PUBLIC POLICY. By the Right Hon. John Bright, M. P. Edited by Professor Thorold Rogers. Two vols. 8vo. 25 s. Second Editicn, with Portrait.

"I have divided the Speeches contained in these voinmes into groups. The materials for selection are so abundant, that I have been constrained" to omit many a speech which is worthy of careful perusal. I have naturally given prominence to those subjects with whach Mr. Bright has been especially identifed, as, for example, India, America, Ireland, ana' Parliannentary Reform. But nearly every topic of great public interest on which Mr. Bright has spoken is represented in these volumes."

Editor's PREFACE. 


\section{Bright (John, M.P.) (continued)-}

AUTHOR'S POPULAR EDITION. Extra fcap. 8vo. cloth. Second Edition. $3 s .6 d$.

Bryce.-The holy ROMAN EMPIRE. By James Bryce, B.C.L., Regius Professor of Civil Law, Oxford. New and Revised Edition. Crown Svo. 7s. $6 d$.

Chatterton: A Biographical Study. By Daniel Wilson, LL.D., Professor of History and English Literature in University College, Toronto. Crown 8vo. 6s. 6d.

The Author here regards Chatterton as a Poet, not as a mere "resetter and defacer of stolen literary treasures." Reviewed in this light, he has found much in the old materials capable of beins turned to new account; and to these materials research in various directions has enabled him to make some additions.

Clay.-THE PRISON CHAPLAIN. A Memoir of the Rev. JoHN

Clay, B.D., late Chaplain of the Preston Gaol. With Selections from his Reports and Correspondence, and a Sketch of Prison Discipline in England. By his Son, the Rev. W. L. Clay, M. A. Svo. I 5 s.

"Few books have appeared of late years better cntitled to an attintize perusal. . . . It presents a complete narrative of all that has been done and attempted by various philanthropists for the amelioration of the condition and the improvement of the morals of the criminal classes in the British dominions."-LONDON REvirw.

\section{Cobden.-SPEECHES ON QUESTIONS OF PUBLIC}

POLiCY. By Richard Cobden. Edited by the Right Hon.

Johr Bright, M.P., and Professor Rogers. Two vols. Svo. With

Portrait. (Uniform with Bright's Speecines.)

The Speeches contained in these two volumes have been selected and edited at the instance of the Cobden Club. They form an important part cr that collective contribution to tolitical science which has conferred on their author so vast a reputation.

Cooper.-ATHEN E CANTABRIgIENSES. By Cinales

Henry Cucper, F.S.A., and Thompson Cooper, F.S.A. Vol. I. 8vo., 1500-85, ISs.; Vol. II., 15S6-1609, ISs.

This elaborate work, which is dedicated by permission to Lord Mircanlay, contains lives of the eminent men sent forth by Cambridge, after the fashion of Anthony à Wood, in his fimous "Athence Oxonienses." 
Cox (G. V., M.A.).-RECOLLECTIONS OF OXFORD. By G. V. Cox, M.A., New College, Late Esquire Bedel and Coroner in the University of Oxford. Second Edition. Crown Sro. IOs. $6 d$.

"An amusing farrago of anecdote, and will pleasantly recall in many a country parsonage the memory of youthful day's."-Times.

“Daily News." - THE WAR CORRESPONDENCE OF THE DAILY NEWS, r87o. Edited, with Notes and Comments, forming a Continuous Narrative of the War between Germany and France. With Maps. Third Edition, recisct. Crown 8vo. 7 s. $6 d$.

This s'olume brings before the pablic in a convenient and fortable form the record of the momentous events which have marked the lust six montis of $\mathrm{I} 87 \mathrm{O}$.

The special ralue of letiers from camps and battle-ficlds consists in the a'vidness with which they reproduce the life and spirit of the scenes and transactions in the midst of which they are written. In the letters which have appeared in the DAILY NEws since the Franco-Prussian War, the public has recognized this quality as present in an eminent degree.

The book begins with a chronology of the war from fuly 4 th, when the French government called out the army reserves, to Decentber 4 th ; the detailes of the campaign are illustrated by four maps representing-I. The ba'tles of Weissenburg and Wörth. 2. The battles of Saarbriicken and Speiecheren. 3. The battle-ficld before Sedan. 4. A plan of Metz and its vicinty.

THE WAR CORRESPONDENCE OF THE DAILY NEWS continued to the Peace. Edited, with Notes and Comments. Second Edition, Crown 8vo. with Map, 7s. 6 6 .

\section{Dicey (Edward).-THE MORNING LAND. By Edward}

Dicey. Two vols. crown 8 vo. I $6 s$.

"An invitation to be present at the opening of the Suez Canal was the immediate cause of my joumey. But I made it my object also to see as much of the Morning Land, of whose marvels the canal across the Isthm un is only the least and latest, as time and opportunity wonld permit. The resuit of my observations was communicated to the joumal I then represented, in a series of letters, which I now gize to the public in a collected form."-Extract from Author's Preface. 
Dilke.-GREATER BRITAIN. A Record of Travel in Englishspeaking Countries during I866-7. (America, Australia, India.) By Sir Chari.es Wentworth Dilke, M.P. Fifth and Cheap Edition. Crown 8vo. 6s.

" Mr. Dilke has weritten a book which is probably as well worth reading as any book of the same aims and character that ever wias woritten. Its merits are that it is written in a lively and agreeable style, that it implies a great deal of physical pluck, that no page of it fails to show an acute and highly intelligent observer, that it stimnulates the imagination as well as the judgment of the reader, and that it is on perhaps the most interesting subject that can attract an Englishman who cares about his country."

Saturday Review.

Dürer (Albrecht).-HISTORY OF TIIE LIFE OF ALBRECHT DÜRER, of Nïnberg. With a Translation of his Letters and Journal, and some account of his works. By Mrs. Charles Heaton. Royal Svo. bevelled boards, extra gilt. 3Is. $6 d$.

This work contains about Thirty Illustrations, ten of which are produc. tions by the Autotype (carbon) process, and are printed in permanent tints by Messrs. Cundall and Flening, under license from the Autotype Conpany', Limited; the rest are Photographs and Woodcuts.

EARLY EGYPTIAN HISTORY FOR THE YOUNG. Sie "Juvenile Section."

Elliott.-LIFE OF HENRY VENN ELLIOTT, of Brighton. By Josini Bateman, M.A., Author of "Life of Daniel Wilson, Bishop of Calcutta," \&c. With Portrait, engraved by JeEss; and an Appendix containing a short sketch of the life of the Rev. Julius Elliott (who met with accidental death while ascending the Schreckhorn in July, I869.) Crown 8vo. 8s. 6d. Second Edition, with Appendix.

"A very charming piece of religious biography; no one can read it zuithout both pleasure and profit."-BRITISH QUARTERIY REVIEW.

EUROPEAN HISTORY, narrated in a Series of Historical Selections from the best Authorities. Edited and arranged by E. M. Seweli. and C. M. Yonge. First Series, crown 8vo. 6s. ; Second Series, I088-1228, crown 8vo. 6s. 
When young children have acquired the outlines of history from abrudgments and catechisms, and it becomes desirable to give a more enlarged view of the subject, in order to render it really usefu! and interesting, a difficulty often arises as to the choice of books. Two courses are open, cither to take a general and consequently dry history of facts, such as Russell's Modern Europe, or to choose some work treating of a particular period or suliject, such as the works of Macaulay and Froude. The former course usually renders history uninteresting; the latter is unsatisfactory, because it is not sufficiently comprehensive. To remedy this difficulty, selections, continuous and chronological, have in the present volume been taken from the larger works of Freeman, Milman, Palgrave, and others, which mav serve as distinct landmarks of historical reading. "We know of scarcely anything," says the Guardian, of this volume, "which is so likely to raise to a higher level the average standard of English education."

\section{Fairfax.-A LIFE OF THE GREAT LORD FAIRFAX,}

Commander-in-Chief of the Army of the Parliament of England. By Clements R. Markinan, F.S.A. With Portraits, Maps, Plans, and Illustrations. Demy Sro. $16 s$.

No full Life of the sreat Parliamentary Commander has afpeared; and it is here sought to produce one-based upon careful research in contemporary records and upon family and other documents.

"ITighly useful to the careful student of the History of the Civil IVar. . . Probably as a military chronicle Mr. Narkham's book is one of the most full and accurate that we possess about the Civil War."Fortnightly Review.

\section{Forbes.-LIFE OF PROFESSOR EDIVARD FORBES,}

F.R.S. By George Wilson, M.D., F.R.S.E., and Archibald Geikie, F.R.S. 8vo. with Portrait, i4s.

"From the first page to the last the book clainns careful reading, as being a full but not overcrowded rehearsal of a most instructive life, and the true picture of a mind that was rare in strength and beauty."-EXAMINER.

\section{Freeman.-IIISTORY OF FEDERAL GOVERNMENT,}

from the Foundation of the Achaian League to the Disruption of the United States. Bv Edward A. Freeman, M.A. Vol. I. General Introduction, History of the Greek Federations. 8vo. $2 \mathrm{I} s$.

"The task Mr. Freeman has undertaken is one of great magnitude and importance. It is also a task of an almost entirely novel character. No 
other work professing to give the history of a political principle occurs io us, except the slight contributions to the history of representative government that is contained in a course of M. Guizot's lectures.... The history of the development of a principle is at least as important as the history of a dynasty, or of a race." - SATURDAY REviEw.

OLD ENGLish history. By Edward A. Freeman, M.A., late Fellow of Trinity College, Oxford. With Five Coloured Maps. Second Edition extra. Fcap. Svo., half-bound. 6s.

"Its olject is to show that clear, accurate, and scientific views of history", or indeed of any subject, may be easily given to children from the very" first... I have, I hope, shown that it is perfectly easy to teach children, from the very first, to distinguish true history alike from legend and from wil/ul invention, and also to understand the nature of historical authorities, and to weigh one statement against another. . . . . I have throughout striven to connect the history of England with the general history of civilized Europe, and I have especially tried to make the book serve as an incentive to a more accurate study of historical geography."-PREFACE.

\section{HISTORY OF THE CATHEDRAL CHURCI OF IVELLS,}

as illustrating the History of the Cathedral Churches of the Old Foundation. By Edward A. Freeman, D.C.L., formerly Fellow of Trinity College, Oxford. Crown Svo. $3^{s .6}$.

"I have here tried to treat the history" of the Church of IVells as a con. trithution to the general historv of the Church and Kingdom of Ensisland, and specially to the history of Cathedrai Churches of the Old Foundation. . . . I wish to point out the general pronciples of the orngunal founders as the model to which the Old Foundations should be brought back, and the New Foundations reformed after their pattern." - PREFACE.

\section{French (George Russell). - SHAKSPEAREANA}

GENEALOGICA. Svo. cloth extra, I5s. Uniform with the "Cambridge Shakespeare."

Part I.-Identification of the dramatis personæ in the historical play's, trom King Fohn to King Henry VIII. ; Notes on Characters in Macbet/ and Hamlet; Persons and Places belonging to Warvickshire alluaed to. Part II.-The Shakspeare and Arden families and their connexions, wit/s Tables of descent. The present is the first attempt to give a detailed description, in consecutive order, of each of the dramatis personæ in Shakspeare's immortal chronicle-histories, and some of the characters have been, 
it is believed, herein identified for the first time A clue is furnished which, followed up with ordinary diligence, may enable any one, with a taste for the pursuit, to trace a distinguished Shakspearean worthy to his lineal representative in the present day.

\section{Galileo.-THE PRIVATE LIFE OF GALILEO. Compiled} principally from his Correspondence and that of his eldest daughter, Sister Maria Celeste, Nun in the Franciscan Convent of S. Matthew in Arcetri. With Portrait. Crown 8vo. 7s. 6d.

It has been the endeavour of the compiler to place before the reader a flain, ungarbled statement of facts; and as a means to this end, to allow' Galilco, his friends, and' his jullges to speak for themselves as far as possible.

\section{Gladstone (Right Hon. W. E., M.P.).-Juventus}

MUNDI. The Gods and Men of the Heroic Age. Crown Sro. cloth extra. With Map. Io.s. $6 d$. Second Edition.

This new work of Mrr. Gladstone deals especially with the historic clennent in Homer, expounding that element and furnishing by its aid a full account of the IIomeric men and the Homeric religion. It starts, after the introductory chapter, with a discussion of the several races then existing in IIellas, including the influence of the Pha'nicians and Esyptians. It iontains chapters on the Olympian system, with its several deities; on the Ellics and the Polity of the Heroic age; on the geography of Homer; on the charactors of the Poens; presenting, in fine, a vicw of primitive life and primitive society as found in the poens of Homer. To this New Eitision zarions additions have been made.

"CLOBE" ATLAS OF EUROPE. Uniform in size with Macmillan's Globe Series, containing 45 Coloured Maps, on a uniform scale and projection; with Plans of London and Paris, and a copious Index. Strongly bound in half-morocco, with flexible back, 9 s.

This Atlas includes all the countries of Europe in a series of 48 Maps, arawn on the same scale, with an Alphabetical Index to the situation of more than ten thousand places, and the relation of the various maps and countries to each other is defined in a general Key-map. All the maps bcing on a uniform scale facilitates the comparison of extent and distance, and conzey's a just impression of the relative magnitude of different conntries. The size suffices to show the provincial divisions, the railways and main roads, the principal rivers and mountain ranges. "This atlas," writes the 
British Quarterly, "will be an invaluable boon for the school, the desk, or the traiveller's portmantcau."

Godkin (James).-THE LAND IVAR IN IRELAND. A History for the Times. By James Godkin, Author of "Ireland and her Churches," late Irish Correspondent of the Times. Svo. I2s. A ITistory of the Irish Land Question.

Guizot.-(Author of "Join Halifax, Gentleman.")-M. DE BARANTE, a Memoir, Biographical and Autobiographical. By M. Guizot. Translated by the Author of "John Halifax, Gentieman." Crown Svo. 6s. 6d.

"The highest furposes of both history and biography are answered by a memoir so lifelike, so faithful, and so philosophical."

Britisil Quarterly Review.

Hole.-A GENEALOGICAL STEMMA OF THE KINGS OF ENGLAND AND FRANCE. By the Rev. C. Hole, M.A., T'rinity College, Cambridge. On Sheet, I $s$.

The different families are printed in distinguishing colours, thus facilitating reference.

A BRIEF BIOGRAPHICAL DICTIONARY. Compiled and Arranged by the Rev. Charles Hole, M.A. Second Edition. I 8 mo. neatly and strongly bound in cloth. $4 s, 6 d$.

One of the most comprehensive and accurate Biographical Dictionaries in the world, contrining more than $\mathrm{I} 8,000$ persons of all countrics, with dates of birth and death, and what they were distingziished for: Extreme care has been bestowed on the verification of the dates; and thus mumerous errors, current in trevious works, have been corrected. Its size adapts it for the desk, portmanteau, or pocket.

"An invaluable addition to our manuals of reference, and, from its moderate price, cannot fail to become as popular as it is useful." - Times.

Hozier.-THE SEVEN WEEKS' WAR; Its Antecedents and its Incidents. By H. M. HozIER. With Maps and Plans. Two vols. Sro. $28 s$.

This work is based upon letters reprinted by permission from "The Times." For the most part it is a product of a personal eye-witness of some of the most interesting incidents of a war which, for rapidity and decisiz'e results, may claim an almost unrivalled position in history. 
THE BRITISH EXPEDITION TO ABYSSINIA. Compiled from Authentic Documents. By Captain Henry M. Hozier, late Assistant Military Secretary to Lord Napier of Magdala. 8vo. 9s.

"Sereral accounts of the British Expedition have been published. .... They haz'e, however, been written by those who hav'e not had access to those authentic documents, which cannot be collected directly after the termination of a campaign..... The endcavour of the author of this sketch has been to present to readers a succinct and impartial account of an enterprise which has rarelv veen equalled in the annals of war."-PREFACE.

\section{Irving.-THE ANNALS OF OUR TIME. A Diurnal of Events,} Social and Political, which have happened in or had relation to the Kingdom of Great Britain, from the Accession of Queen Victoria to the Opening of the present Parliament. By JosEPH IRvivg. Second Edition, continued to the present time. Svo. half-bound. I8s.

[Immediately'.

"We have before us a trusty and ready guide to the events of the past thirty years, arailable equally for the statesman, the politician, the fublic writer, and the general reader. If Mr. Irving's object has becn to bring before the reader all the most notivorthy occurrences which have hafpened sunce the beginning of Her Maxjesty's reign, he may justly clain the credit of having done so most briefly, succinctly, and simply, and in such a manner, too, as to furnish him with the detizils necessary in each case to comprehend the event of which he is in search in an intelli, rent manner. Reflection will serve to show the great value of such a work as this to the journalist and statesman, and indecd to every one werho feels an interest in the progress of the age; and we may add that its value is considerably increased by the addition of that most important of all appendices, an accurate and instructive index."-Times.

\section{Kingsley (Canon).-ON THE ANCIEN REGIME as it} existed on the Continent before the Frexch REvolution. Three Lectures delivered at the Royal Institution. Py the Rev. C. Kingsley, M.A., formerly Professor of Modern History in the University of Cambridge. Crown 8vo. 6 s.

These three lectures discuss severally (1) Caste, (2) Centralization, (3) The Explosive Forces by which the Revolution was superinduced. The Preface deals at some length with certain folitical questions of the present dicy. 
THE ROMAN AND THE TEUTON. A Series of Lectures delivered before the University of Cambridge. By Rev. C. Kingsley, M.A. Svo. $12 s$.

Contents :-Inaugural Lecture; The Forest Children; The Dying Empire; The Human Deluge; The Gothic Civilizer; Dietrich's End; The Nemesis of the Goths; Paulus Diaconus; The Clergy and the Heathen: The Monk a Civilizer; The Lombard Laws; The Popes and the Lombards; The Strategy of Providence.

\section{Kingsley (Henry, F.R.G.S.).-TALES OF OLD}

TRAVEL. Re-narrated by Hexry Kingsley, F.R.G.S. With Eight Illustrations by HUARD. Third Edition. Crown 8vo. 6s.

Contents :-HFarco Po'o; The Shipwreck of Pelsart; The Wonderful Adventures of Andrew Battel; The Wanderings of a Capuchin; Peter Carder; The Freservation of the "Terra Nova;" Spitzbergen; D'Ermenonville's Acclimatization Adventure; The Old Slave Trade; Miles Philits; The Sufferings of Robert Everard; Foln Fox; Alvaro Nunez; The Foundation of an Emioire.

Latham.-BLACK AND WHITE: A Journal of a Three Months' Tour in the United States. By Henry Latham, M.A., Barristerat-Law. Svo. ICs. $6 d$.

"The spirit in which Mrr. Latham has written about our brethren in Ancrica is commendable in ligh degree."-ATHenduM.

Law.-THE ALPS OF HANNIBAL. By William JoHn LAw, M.A., formerly Student of Christ Church, Oxford. Two vols. Sro. 21 s.

"No one can read the work and not acquire a conviction that, in adilition to a thorough grasp of a particular topic, its writer has at command a large store of reading and thought upon many cognate points of ancient history aind geograpliy."-QUARTERLY REVIEW.

Liverpool.-THE LIFE AND ADMINISTRATION OF ROBERT BANKS, SECOND EARL OF LIVERPOUL, K.G. Compiled from Original Family Documents by Charles Duke Yosge, Regrius Professor of History and English Literature in Queen's College, Belfast; and Author of "The History of the British Navy," "The History of France under the Bourbons," etc. Three vols. Svo. $42 s$. 
Since the time of Lord Burleigh no one, except the second Pitt, evier enjoyed so long a tenure of power; with the same exception, no one eiter held office at so critical a time ... . Lord Liverpool is the very last minister who has been able fully to carry ont his own political views; who has been so strong that in matters of general policy the Opposition conla? ixtort no concessions from him which were not sanctioned by his own deliberate judgment. The present work is founded almost entirely on the correspondence left behind him by Lord Liverpool, and now in the possession of Colonel and Lady Catherine Harcourt.

"Full of information and instruction."-ForTNightLy Review.

\section{Macmillan (Rev. Hugh).-HOLIDAYS ON HIGH}

LANDS ; or, Rambles and Incidents in search of Alpine Plants. By the Rev. Hugh Macmillan, Author of "Bible Teachings in Nature," etc. Crown 8vo. cloth. $6 s$.

"Botanical knowledge is blended with a love of nature, a pious enthusiasm, and a rich felicity of diction not to be met with in any works of kindred character, if we except those of Hugh Miller."-D.IILY TELEGRAPH.

FOOT-NOTES FROM THE PAGE OF NATURE. With numerous Illustrations. Fcap. Svo. 5 s.

"Those who have derived pleasure and profit from the study of flowers and ferns-subjects, it is pleasing to find, now everywhere popular-by descending lower into the arcana of the vegetable kingdom, will find a still more interesting and delightful field of research in the objects brought under review in the following pages."-PREFACE.

BIBIE TEACHINGS IN NATURE. Fifth Edition. Fcap. 8vo. $6 s$.

Martin (Frederick)._THE STATESMíAN'S YEAR-BOOK:

A Statistical and Historical Account of the States of the Civilized World. Manual for Politicians and Merchants for the year $187 \mathrm{I}$. By Frederick Martin. Eighth Annual Publication. Crown 8vo. I0s. $6 d$.

The new issue has been entirely re-uritten, revised, and corrected, on the basis of official reports received direct from the heac's of the leading Goivrinments of the World, in reply to letter's sent to them by the Editor. 


\section{Martin (Frederick).-(continuca)-}

"Everybody" who knows this work is aware that it is a book that is indis. pensable to writers, financiers, politicians, statesmen, and all who are directly or indirectly interested in the political, social, industrial, commercial, and financial condition of their fellow-creatures at home and abroad. Mr. Martin deserves warm commendation for the care he takes in making 'The Statesman's Year Book' complete and correct."

STANDARD.

HANDBOOK OF CONTEMPORARY BIOGRAPHY. By Frederick Martin, Author of "The Statesman's Year-Book." Extra fcap. Svo. 6s.

This volume is an astempt to produce a book of reference, furnishing in a condensed form some biographical particulars of notable living mon. The leading ulea has been to give only facts, and those in the briejest form, and to exclude opinions.

Martineau.-BIOGRAPHICAL SKETCHES, I852-IS6S. By Harriet Martineau. Third and cheaper Edition, with New Preface. Crown 8vo. 6s.

A Collection of Memoirs under these several sections:-(1) Royal, (2) Politicians, (3) Professional, (4) Scientific, (5) Social, (6) Literary. These Memoirs afpeared originally in the columns of the "Daily News."

Milton.-LIFE OF JOHN MILTON. Narrated in connexion with the Political, Ecclesiastical, and Literary History of his Time. By David Masson, M.A., LL.D., Professor of Rhetoric at Edinburgh. Vol. I. with Portraits. Svo. I8s. Vol. II. in a few days. - Vol. III. in the Press.

It is intended to exhibit Milton's life in its connexions with all the more notable phenomena of the period of British history in which it was castits state politics, its ecclesiastical variations, its literature and speculative thought. Commencing in 1608 , the Life of Milton proceeds through the last sixteen years of the reign of Fames I., includes the whole of the reign of Charles I. and the subsequent years of the Commonwealth and the I'rotectorate, and thon, passing the Restoration, extends itself to 1674 , or 
through fourteen years of the new state of things under Charles II. The first volume deals with the life of Milton as extending from 1608 to 1640 , which was the period of his education and of his minor poems.

Mitford (A. B).-TALES OF OLD JAPAN. By A. B. Mitford, Second Secretary to the British Legation in Japan. With upwards of 30 Iilustrations, drawn and cut on Wool by Japanese Artists. Two vols. crown Svo. 21 s.

This work is an attempt to do for Fupan what Sir F. Davis, Dr. Legge, and M. Stanislas Fulien, have done for China. Under the influence of more enlightened ideas and of a liberal system of policy, the old Fapanese civilization is fast disappearing, and will, in a few years, be completely extinct. It was important, therefore, to preserve as far as possible trusiworthy records of a state of society which although venerabie from its antiquity, has for Europeans the dawn of novlty; hence the serics of narratives and legends translated by Mr. Mitford, and in which the Fapanese are very judiciously left to tell thcir own tale. The two volumes comtrise not only stories and episodes i!lustrative of Asiatic superstivions, but also three sermons. The preface, appendices, ard notes explain a number of local peculiarities; the thirty-one woodcuts are the gennine work of a native artist, who, unconsciously of rourse, has adopted the process first introduced by the early' German mastcrs.

Morley (John).-EDMUND BURKE, a Historical Study By John Morley, B.A. Oxon. Crown 8vo. 7s. $6 d$.

"The style is terse and incisive, and brilliant with epigram and point. It contains pithy aphoristic sentences which Burke himself would not have?

\section{Morison.-THE LIFE AND TIMES OF SAINT BERNARD,}

Abbot of Clairvaux. By James Cotter Morison, M.A. New Ldition, revised. Crown Svo. 7 s. $6 d$.

"One of the best contributions in our literature towards a vivid, intelligent, and worthy knowledge of European mterests and thonghts and feelings during the twelfth century. A delightful and instructive volume, and one of the best products of the modern historic spirit."

pall Mall Gazette. 
disowned. But these are not its best features: its sustained poiver of reasoning, its wide sweep of observation and reflection, its elevated ethical ana' social tone, stamp it as a work of high excellence, and as such we cordially recommend it to our readers."-SATURDAY REviEw.

Mullinger.-CAMBRIDGE CHARACTERISTICS IN THE SEVEnTEenth Century. By J. B. Mullinger, B.A. Crown 8vo. 4s. $6 d$.

| "It is a very entertaining and readable book."-SATURDAY REview.

"The chapters on the Cartesian Philosophy" and the Cambridge Platonists are admirable."-ATHENæUM.

\section{Palgrave.-HISTORY OF NORMANDY AND OF ENG-} LAND. By Sir Francis Palgrave, Deputy Keeper of Her Majesty's Public Records. Completing the History to the Deatli of William Rufus. Four vols. Svo. $£ 44 s$.

Volume I. General Relations of Mediveval Europe-The Carlovingian Empire-The Danish Expeditions in the Gauls-And the Estublishment of Rollo. Volume II. The Three First Dukes of Normandy; Rollo, Guillaume Longue-Épé, and Richard Sans-Peur-The Carlozingian line supplanted by the Capets. Volume III. Richard Sans-PeurRichard Le-Bon-Richard III.-Robert Le Diable-William the Conqueror. Volume IV. Williani Rufus-Accession of Henry Deauclerc.

Palgrave (W. G.).-A NARRATIVE OF A YEAR'S JOURNEY THROUGH CENTKAL AND EASTERN ARABIA, iS62-3. By William Gifford Palgrave, late of the Eighth Regiment Bombay N. I. Fifth and cheaper Edition. With Maps, Plans, and Portrait of Author, engraved on steel by Jeens. Crown Svo. 6s.

"Considering the extent of our frevious ignorance, the amount of his achievements, and the importanc. of his contributions to our knowledge, we cannot say less of him than was once said of a far greater discoverer. Mr. Palgrave has indecd given a new world to Europe."

; Pal.l Maill Gazette. 


\section{Parkes (Henry).-AUSTRALIAN viEWS OF ENGLAND. By Henry Parkes. Crown 8vo. cloth. $3 s .6 d$.}

"The following letters were written during a residence in England, in the ycars I86I and I862, and were published in the "Sydney Morning Herald" on the arrival of the monthly mails.... On re-perusal, these letters appear to contain viewer of English life and impressions of English notabilities which, as the views and impressions of an Englishman on his return to his native country afteran absence of twenty years, may not be without interest to the English reader. The wuriter had opportunities of mixing with different classes of the British people, and of hearing opinions on passing events from opposite standpoints of observation." --AUTHOR'S P'REFACE.

Prichard.-THE ADMINISTRATION OF INDIA. From I 359 to I868. The First Ten Years of Administration under the Crown. By Iltudus Thomas Prichard, Barrister-at-Law. Two vols. Demy Svo. With Map. 2 I $s$.

In these volumes the author has aimed to supply a full, impartial, and independent acconnt of British India between I859 and IS68-which is m many respects the most important epoch in the history of that country which the present century has seen.

Ralegh.-THE LIFE OF SIR WALTER RALEGH, based upon Contemporary Documents. By Edward Edwards. Together with Ralegh's Letters, now first collected. With Portrait. Two vols. Svo. $32 s$.

"Mr. Edwards has certainly written the Life of Ralegh from fuller information than any previons biographer. He is intelligent, industrious, simpathetic: and the world has in liis two volumes larger means afforded it of knowing Ralegh than it ever possessed before. The new letters and the newily-edited old letters are in thennselves a boon."-PALL MALL. (iAZETTE.

Robinson (Crabb).--DIARY, REMINISCENCES, ANU CORRESPONDENCE OF HENRY CRABB ROBINSON. Selected and Edited by Dr. SAdLer. With Portrait. Second Edition. Three vols. Sro. cloth. $36 s$. 
Mr. Crabb Robinson's Diary extends over the greater part of threequarters of a century. It contains personal reminiscences of some of the most distinguished character's of that period, including Goethe, IVieland, De Quincey, Wordsworth (with whom Mr. Crabb Robinson was on terms of sreat intimacy), Madame de Staël, Lafayette, Coleridge, Lamb, Milman, SNc. Soc.: and includes a vast variety of subjects, politicul, literar'", ecclesiastical, and miscellaneous.

Rogers (James E. Thorold).-MISTORICAL GLEANINGS : A Séries of Sketches. Montague, Walpole, Adam Smith, Cobbett. By Professor Rogers. Crown 8vo. 4s. $6 d$.

Professor Rogers's object in the following sketches is to present a set of historical fucts, grouped round a principal figure. The essay's are in the form of lectures.

HISTORICAL GLEANINGS. Second Series. Crown 8vo. $6 s$.

A companion volume to the First Series recently published. It contains papers on Wiklif, Laud, Wilkes, Horne Tooke. In these lectures the author has aimed to state the social facts of the time in which the individnal whose history is handled took part in public business.

Smith (Professor Goldwin).- THREE ENGLISH STATESMEN : PYM, CROMWELL, PITT. A Course of Lectures on the Political History of England. By GoLdwin Surth, M.A. Extra fcap. Svo. New and Cheaper Edition. $5^{s}$.

"A work which nenther historian nor politician can safely afford to niglect."-SATURDAY Review.

SYSTEMS OF LAND TENURE, IN VARIOUS COUNTRIES.

A Series of Essays published under the sanction of the Cobien Club. Demy 8ro. Second Edition. I2s.

The subjects treatat are:-1. Tenure of Land in Treland; 2 . Land Laws of England; 3. Tenne of Land in India; 4. Land System of Bilgium and Holland; 5. Agrarian Legislation of Prussia during the Present Century; 6. Land System of France; 7. Russian Agrarian Legislation of IS6r; S. Farm Land and Land Laws of the Cnated Stutes. 
Tacitus.-THE HISTORY OF TACITUS, translated into English. By A. J. Church, M.A. and IV. J. Brodribb, M.A. With a Map and Notes. 8vo. Ios. 6 .

The translators have endearioured to adhere as closely to the original as was thought consistent with a proper observance of English idiom. At the same time it has been their aim to reproduce the precise expressions of the author. This work is characterised by the Spectator as "a scholarly and faithful translation."

THE AGRICOLA AND GERMANIA. Translated into English by A. J. Church, M.A. and IV. J. Bronribb, M.A. With Maps and Notes. Extra fcap. Sro. 2s. $6 d$.

The translators have sought to produce such a version as may satisfy scholars who demand a faithful rendering of the original, and English readers who are offended by the baldness and frigidity ashich commonly disfigure translations. The treatises are accompanied by introductions, notes, maps, and a chronological summary. The Athenæum says of this work that it is "a version at once readable and exact, which may be perused with pleasure by all, and consulted with advantage by the classical student."

Taylor (Rev. Isaac).-WWRDS AND PLACES; or Etymological Illustrations of History, Etymology, and Geography. By the Rev. IsaAc Taylor. Second Edition. Crown 8vo. I2s. $6 d$.

"Mr. Taylor has produced a really useful book, and one which stands alone in our language."-SATURDAY Review.

Trench (Archbishop).-GUSTAVUS ADOLPHUS : Social Aspects of the Thirty Years' War. By R. Chenevix Trench, D. D., Archbishop of Dublin. Fcap. Svo. 2s. $6 d$.

"Clear and lucid in style, these lectures will be a treasure to many to whom the subject is unfomiliar." -DUblin Evening MAIL.

Trench (Mrs. R.).-Remains of the late Mrs. RICHARD TRENCH. Baing Selections from her Joumals, Letters, a: d other Papers. Edited by Archishop Trench. New and Cheaper Issue, vith Portrait, 8vo. 6s. 
Contains notices and anecdotes illustrating the social life of the period -extending over a quarter of a century (1799-1827). It includes also poems and other miscellaneous pieces by Mrs. Trench.

\section{Trench (Capt. F., F.R.G.S.).-THE RUSSO-INDIAN}

QUESTION, Historically, Strategically, and Politically considered. By Capt. Trench, F.R.G.S. With a Sketch of Central Asiatic Politics and Map of Central Asia. Crown 8vo. 7s. $6 d$.

"The Russo-Indian, or Central Asian question has for several obviou's reasons been attracting much public attention in Engiand, in Russia, and also on the Continent, within the last year or two. . . . I have thought that the present volume, giving a short sketch of the history of this question from its earliest origin, and condensing much of the most recent and interesting information on the subject, and on its collateral phases, might perhaps be acceptable to those who take an interest in it."-AUTHOR's PREFACE.

Trevelyan (G.O., M.P.).-CA WNPORE. Illustrated with Plan. By G. O. Trevelyan, M.P., Author of "The Competition Wallah." Second Edition. Crown 8vo. 6s.

"In this book we are not spared one fact of the sad story; but our feelings are not harrowed by the recital of imaginary outrages. It is good for us at home that we have one who tells his tale so well as does Mr. Trevelyan."-Pall Mall Gazette.

THE COMpetition wallah. New Edition. Crown Svo. 6s.

"The earlier letters are especially interesting for their racy descriptions of European life in India. . . . . Those that follow are of more serious import, seeking to tell the truth about the Hindoo character and English influences, good and bad, upon it, as well as to suggest some better course of treatment than that hitherto adopted."-EXAMINER.

\section{Vaughan (late Rev. Dr. Robert, of the British Quarterly).-MEMOIR OF ROBERT A. VAUGHAN.} Author of "Hours with the Mystics." By RoberT VAUghas, D.D. Second Edition, revised and enlarged. Extra fcap. 8vo. $5^{s}$. "It deserves a place on the same shelf with Stanley's 'Life of A mold,' and Carlyle's 'Stirling.' Dr. Vaughan has performed his painful but not all unfleasing task with exquisite good taste and feeling." -NONCONFORMIST. 
Wagner.-MEMOIR OF THE REV. GEORGE WAGNER, M.A., late Incumbent of St. Stephen's Church, Brighton. By the Rev. J. N. Simpkinson, M.A. Third and Cheaper Edition, corrected and abridged. 5 s.

"A more edifying biosraphy we have rarely met with."-LITERARY Churchman.

Wallace.-THE MALAY ARCHIPELAGO: the Land of the Orang Utan and the Bird of Paradise. A Narrative of Travel with Studies of Man and Nature. By Alfred Russel Wallace. With Maps and Illustrations. Second Edition. Two vols. crown Svo. 2.4s.

"A carefully and deliberately composed narrative. . . . We advise our readers to do as we have done, read his book through." -Times.

Ward (Professor).- - THE HOUSE OF AUSTRIA IN THE THIRTY YEARS' IVAR. Two Lectures, with Notes and Illustrations. By Adolphus IV. WARd, M.A., Professor of History in Owens College, Manchester. Extra fcap. Svo. 2s. 6d.

" Very compact and instructive."-ForTwightily Revifw.

Warren.-AN ESSAY ON GREEK FEDERAL COINAGE. By the Hon. J. Leicester WArren, M.A. Svo. 2s. $6 a$.

"The present essay is an attempt to illustrate Mr. Freeman's Federal Government by exidence deducel from the coinage of the times and countries therein treatid of."-PREFACE.

Wedgwood.-JOHN WESLEY AND THE EVANGELICAL REACTION of the Eighteenth Century. By JULIA WEDGwood.

Crown Svo. Ss. $6 d$.

This book is an attempt to delineate the influence of a particular man upon his ase.

Wilson.-A MEMOIR OF GEORGE WILSON, M. D., F.R.S.E., Regius Professor of Technology in the University of Edinburgh. By his Sister. New Edition. Crown Svo. 6s. "An exquisite and touching fortrait of a rave and beautiful spirit."GuARDJAN. 


\section{Wilson (Daniel, LL.D.).-PREHISTORIC ANNALS} OF SCOTLAND. By Daniel Wilson, LL.D., Professor of History and English Literature in University College, Toronto. New Edition, with numerous Illustrations. Two vols. demy 8vo. $36 s$.

This elaborate and learnea work is divided into four Parts. Part $I$. deals with The Primeval or Stone Period : Aboriginal Traces, Sepulchral Memorials, Dwellings, and Catacombs, Temples, WVeatons, \&cc. Evc.; Part 1I., The Bronze Period: The Metallurgic Transition, Primitive Bronze, Personal Ornaments, Religion, Arts, and Domestic Habits, with other topics; Part III., The Iron Period: The Introduction of Iron, The Roman Invasion, Strongholds, Erc. Eoc.; Part IV., The Christian Period: Historical Data, the Norrie's Law Relics, Primitive and Mediaval Ecclesiology, Ecclesiastical and Miscellaneous Antiquities. 'Th' work is furnished with an elaborate Index.

PREHISTORIC MAN. New Edition, revised and partly re-written, with numerous Illustrations. One vol. 8vo. 21s.

This work, which carries out the principle of the preceding one, but with a wider scope, aims to "view MIan, as far as possible, unaffected by those modifying infuences which aicompany the development of nations and the maturity of a true historic period, in order thereby to ascertain the sources from whence such development and maturity proceed." It contains, for example, chapters on the Primeval Transition; Speech; Metals; the Mound-Builders; Primitive Architecture; the American Type; the R'd Blood of the West, Erc. Evc.

CHATtERTON: A Biographical Study. By Daniel Wilson, LL.D., Professor of History and English Literature in University College, Toronto. Crown Sro. 6s. $6 d$.

The Author here regards Chatterton as a Poet, not as a "mere resetter and defacer of stolen literary treasures." Reviewed in this light, he has found much in the old materials capable of being tumed to new account: and to these materials research in various directions has cnabled hum to make some additions. 
Yonge (Charlotte M.)-A PARALlet HISTORY OF FRANCE, AND ENGLAND : consisting of Outhes and Dates. By Charlotte M. Yoxge, Author of "The Heir of Redclyffe," "Cameos from English History," \&c. \&c. Oblong 4to. 3s. $6 d$. This tabular history has been drai'n up to snftly a want felt by many teachers of some means of making their pusils realize what events in the two countries were contemporary. A skeleton narrative has been constructed of the chief transactions in eitier country', placing a column betwecn for what affected both alike, by which means it is hoped that young people may' be assisted in grasping the mutual relation of eients. 


\section{SECTION II.}

\section{POETRY AND BELLES LETTRES.}

\section{Allingham.-LAURENCE BLOOMFIELD IN IRELAND}

or, the New Landlord. By William Allinghair. New and

Cheaper Issue, with a Preface. Fcap. Svo. cloth, $4 s .6 d$.

In the new Preface, the state of Ireland, with special refcrence to the Church measure, is discussed.

"It is vital with the national character. . . . It has something of Pope's point and Goldsmith's simplicity, touched to a more modern issue."Athen.eun.

Arnold (Matthew).-POEMS. By Matthew Arnoln. Two vols. Extra fcap. Svo. cloth. I2s. Also sold separately at $6 s$. each.

Volume 1. contains Narrative and Elegiac Poens; Volume 1I. Dramatic and Lyric Poins. The two volumes comprehend the First and Second Series of the Poems, and the New Poems.

NEIV POEMS. Extra fcap. Svo. 6s. $6 d$.

in this volume will be found "Empedocles on Etna;" "Thyrsis" (written in commemoration of the late Professor Clough); "Epilogue to Lessing"s Lavcoön;" "Heine's Grave;" "Obermann once more." All these poems are also included in the Edition (two vols.) above-mentioned.

ESSAYS IN CRITICISM. New Edition, with Additions. Extra fcap. Svo. $6 s$.

Contents :-Preface; The Function of Criticism at the present time; The Lilerary Influence of Acadcmies; Maurice de Guerin; Euscnie de Guerin; Heinrich Heine; Pagan and Mediaval Religions Sentimut; Foubert: Spinoza and the Bible; Marcus Aurelius. 
ASPROMONTE, AND OTHER POEMS. Fcap. Svo. cloth extra. 4 s. $6 d$.

Contents:-Poems for Italy; Dramatic Lyrics; Miscellaneous.

"Uncommon lyrical power and acep poetic feeling."-LITERARY CHURCHMAN.

Barnes (Rev. W.).-POEMS OF RURAL LIFE IN COMMON ENGLISH. By the REv. W. Barnes, Author of "Poems of Rural Life in the Dorset Dialect." Fcap. 8vo. 6 s.

"In a high degree pleasant and norcl. The book is by no mcans one which the lovers of descriptive foctry can afford to lose."-A THENÆUM.

Bell.-ROMANCES AND MINOR PGEMS. By HeNky Glassford Bell. Fcap. Sro. 6s.

"Full of life and genius."-COURT Circular.

Besant.-STUdIES IN EARLY FRENCH POETRY. By Walter Besant, M.A. Crown. Sro. 8s. $6 d$.

A sort of imfression rests on most minds that French literature begins with the "siecle de Louis Quatorze;" any prezious literature being for the most part unknown or ignord. Fize know anything of the enormous litcrary activity that began in the thirtecnth century, was carricd on by Rulibut, Marie de France, Gaston de Foix, Thibault de Champas'ne, and Lorris; wues fostered by Charics of Orleans, by Margaret of Valois, by Francis the First; that gave a crowd of zersifiers to France, envichad, strengthened, devclofed, and fixcd the French language, and frepared the way for Corneille and for Racinc. The prestnt work aims to afford information and direction touching the carly efforts of France in poetical literature.

"In one moderately sized volume he has contrived to introduce us to the very best, if not to all of the early French foets."-ATHENAUM.

Bradshaw.-AN ATTEMPT TO ASCERTAIN THE STATE OF CHAUCER'S IVORKS, AS THEY WERE LEFT AT HIS DEATH. With some Notes of their Subsequent History. By Henry Bradshaw, of King's College, and the University Library, Cambridge.

In the Fress. 
Brimley.-ESSAYS BY THE LATE GEORGE BRIMLEY, M.A. Edited by the Rev. IV. G. Clark, M.A. With Portrait. Cheaper Edition. F cap. Sro. 3s. 6 .

Essay's on literary topics, such as Tenny'son's "Poemis," Carlyle's "Lite of Stirling," "Bleak House," \&oc., reprinted from Fraser, the Spectator, and like periodicals.

Broome.-TIIE STRANGER OF SERIPHOS. A Dramatic Poem. By Frederick Napier Broome. Fap. Svo. 5 s.

Founced on the Greek legend of Danae and Persens.

"Grace and beauty" of expression are MTr. Broome's characternstics; and these qualities are displayed in many passages."-A AnENAum.

Church (A.J.).-HORÆ TENNYSONIANÆ, Sive Eclogæ e Tennysono Latine redditæ. Cura A. J. Church, A.M. Extra fcap. 8vo. 6s.

Latin versions of Selections from Tennyson. Among the authors are the Editor, the late Professor Coningion, Professor Seeley', Dr. Hesscy, Nr. Kebbel, and other gentlemen.

Clough (Arthur Hugh).--THE POEMS AND PROSE REMAINS OF ARTHUR HUGH CLOUGI. With a Selection from his Letters and a Memoir. Edited by his Wife. With Portrait. Two vols. crown Sro. 2Is. Or Poems sepa. rately, as below.

The late Professor Clough is well knowon as a graceful, tender poet, and as the scholarly tranislator of Flutarch. The letters possess high interest, not biographical only, but literary-discussing, as they do, the most important questions of the time, alway's in a genial spirit. The "Remains" include papers on "Retrenchment at Oxford;" on Professor F. W. Nezwnan's book "The Soul;" on W'ordsworth; on the Formation of Classical English; on some Modern Pocms (Matthew Arnold and the late Alexainder Smith), \&c. \&.c.

THE POEMS OF ARTHUR HUGH CLOUGH, sometime Fellow of Oriel College, Oxford. Third Edition. Fcap. 8vo. 6s. 
"From the higher mind of cultivated, all-questioning, but still conservative England, in this our puzaled generation, we do not know of anv utterance in literature so characteristic as the poens of Arthur Hugh Clough."-Fraser's MAGAZINE.

Dante.-DANTE'S COMEDY, THE HELL. Translated by IV. M. Rossetti. Fcap. 8vo. cloth. 5s.

"The aim of this translatzon of Dante may be summed up in one word - Literality. . . . To follow Dante sentence for sentence, line for line, word for word-neither more nor less-has been my strinuons endeavour." -Author's Preface.

De Vere.-THE INFANT BRIDAL, and other Poems. By Aubrey De Vere. Fcap. 8vo. 7s. $6 d$.

"Mr. De Vere has taken his place among the poits of the day. Pure and tender feeing, and that polished restraint of sty'e which is called classical, are the charms of the volume."-SPECTATOR.

Doyle (Sir F. H.).-Works by Sir Francis Hastings Doyle, Professor of Poetry in the University of Oxford :-

THE RETURN OF THE GUAARD, AND OTHER POEMS. Fcap. Svo. $7 s$.

"Good wine needs no bush, nor grood verse a preface; and Sir Francis Doyle's verses run bright and clear, and smack of a classic vintage. . . . His chief characteristic, as it is his greatest charm, is the simple manliness which gives force to all he writes. It is a characteristic in these day's rare enongh."-EXAMINER.

LECTURES ON POETRY, delivered before the University of Oxford in IS68. Crown 8vo. 3s. $6 d$.

Three Lectures :- (I) Inansural; (2) Provincial Poetry'; (3) Dr. Newman's "Dream of Gerontins."

"Full of thoushtful discrimination and fine insight: the lecture on 'Provincial Puetry' seens to us singularly true, eloquent, and instructive." -Spectator.

Evans.-BROTHER FABIAN'S MANUSCRIPT, AND OTher POems. By Sebastian Evans. Fcap. Sro. cloth. 6s. 
"In this volume we have full assurance that he has 'the vision and the faculty divine.' . . . Clever and full of kindly humour."-GLOBE.

Furnivall.-LE MORTE D'ARTHUR. Edited from the Harleian M.S. 2252, in the British Museum. By F. J. Furnivall. M.I. A. With Essay by the late Herbert Coleridge. Fcap. 8vo. 7 s. $6 d$.

Looking to the interest shown by so many thousands in Mr. Tennyson's Arthurian poems, the editor and publishers have thought that the old version would possess considerable interest. It is a reprint of the celebrated Harleian copy ; and is accompanied by index and glossary.

Garnett.-IDYLLS AND EPIGRANS. Chiefly from the Greek Anthology. By Ricilaid Garnett. Fcap. Svo. 2s. $6 d$.

"A charming little book. For Englis/2 readers, Mr. Garnett's translalations will open a new world of thought." - WestMINSTER Review.

GUESSES AT TRUTH. By Two Brothers. With Vignette, Title, and Frontispiece. New Edition, with Memoir. Fcap. Svo. 6s.

"The following year was memorable for the commencement of the 'Guesses at Truth.' He and his Oxford brother, living as they did in constant and free interchange of thought on questions of philosophy and literature and art; delighting, each of them, in the epigrammatic terseness whuch is the charm of the 'Pensées' of Pascal, and the 'Caractires' of La Bruyerre-agreed to uttcr themselves in this form, and the book appared, anonymously, in two volumes, in I827."-MFMoIR.

Hamerton.-A PAINTER'S CAMP. By Philip Gilbert Hamerton. Second Edition, revised. Extra fcap. Svo. $6 s$.

Book I. In England; Book II. In Scotland; Book III. In France. This is the story of an Artist's encampments and adventures. The headings of a few chapters may serve to convey a notion of the character of the book: A Walk on the Lancashire Nloors; the Author his own Housekeeper and Cook; Tents and Boats for the Highlands; The Author encamps on an uninhabited Island; A Lake Voyage; A Gipsy Fourney to Glen Coe; Concerning Mloonlight and Old Castles; A little Fronch City; A Farm in the Autunois, Sc. Soc. 
"His pages sparkle with many turns of expression, not a few well-told anecdotes, and many observations winch are the frunt of attentive study' and wise reflection on the complicated phenomena of human life, as well as of unconscious nature."-WESTMINSTER REVIEW.

ETCHING AND ETCHERS. A Treatise Critical and Practical. By P. G. Hamerton. With Original Plates by Rembrandt, Callot, Dujardin, Paul Potter, \&c. Royal Sro. Half morocco. $3 \mathrm{I} s, 6 d$.

"It is a work of which author, printer, and publisher may alike feel proud. It is a work, too, of which none but a genuine artist could bv possibility have been the author."-SATURDAY REviEW.

Herschel.-THE ILIAD OF HOMER. Translated into English Hexameters. By Sir John Herschel, Bart. 8vo. i $8 s$.

A version of the Iliad in English Hexameters. The question of Homeric translation is fully discussed in the Preface.

"It is admirable, not only for many intrnsic merits, but as a great man's tribute to Genius."-Illustrated London News.

HIATUS : the Void in Modern Education. Its Canse and Antidote. By Outis. Svo. Ss. $6 d$.

The main object of this Essay is to point out how the emotional element which anderlies the Fine Arts is disregarded and undereloped at this time so far as (despite a pretence at filling it up) to constitute an Educational Hiatus.

Huxley (Professor).-LAY SERMONS, ADDRESSES, AND REviEWS. By T. H. Huxley, LL.D., F.R.S. Second and Cheaper Edition, crown Sro. $7 s .6 d$.

Fourtien discourses on the following subjects:-On the Advisableness of Improving Natural Knowledge Emancipation-Black and White; A Liberal Education, ana where 20 find it; Scientific Education; on the Educational Value of the Natural History Sciences; on the Study of Zoolosy; on the Physical Basis of Life; the Scientific Aspects of Positi ism; on a Piece of Chalk; Gealogical Contemporaneity and Persistent Tjites of Life; Geological Reform; the Origin of Species; Criticismes on thie "Origin of Species;" on Descartes" "Dtscourse touching the Method of usins one's Reason rightly and of seeking Scientific Truth." 
ESSAYS SELECTED FROM LAY SERMONS, ADDRESSES, AND REVIEWS. Crown Svo. Cloth. 2s.

Whilst publishing a second edition of his Lay Sermons, Addresses, and Reviews, Professor Huxley has, at the suggestion of many friends, issued m a chcap and popular form the selection we are now noticing. It includes the following essays:-(I) On the Advisablentess of Improving Natural Knowild dre. (2) A Liberal Education, and where to find it. (3) Scientific Education, notes of an after-dinner speech. (4) On the Physical Basis of Life. (5) The Scientific Astects of Positivism. (6) On Descartes' "Discourse touching the Method of using one's Reason Rightly and of seeking Scientific Truth."

Kennedy.-LEGENDARY FICTIONS OF THE IRISH CELTS. Collected and Narrated by Patrici Kennedy. Crown Sro. With Two Illustrations. $7 s, 6 d$.

"A very" admirable popuiar selection of the Irish fairy stories and legends, in which those who are familiar with $\mathrm{Mr}$. Croker's, and other selections of the same kind, will find much that is fresh, and full of the peculiar vivacity and humour, and sometimes even of the ideal beautv', of the true Celtic Legenul."-SPECTATOR.

Kingsley (Canon).--See also "Historic Section," "Works of Fiction," and "Philosophy;" also "Juvenile Books," and "Theology."

THE SAINTS' TRAGEDY : or, The True Story of Elizabeth of Hungary. By the Rev. Charles Kingsley. With a Preface by the Rev. F. D. Maurice. Third Edition. Fcap. 8vo. 5 s.

ANDROMEDA, AND OTHER POEMS. Third Edition. Fcap. Sro. 5 s.

PHAETHON;: or, Loose Thoughts for Loose Thinkers. Third Edition. Crown Svo. $2 s$.

Lowell (Professor).-AMONG MY BOOKS. Six Essays. By TAmes Russell Lowbld, M.A., Professor of Belles Lettres in Harvar College. Crown Svo. $7 s, 6 d$. 
Six Essays: Dryden ; Witchcraft; Shakespeare Once More; New England Two Centuries ago; Lessingt; Rousseau and the Sentimentalists.

UNDER THE WILlOWS, AND OTHER POEMS. By JAMES Russell Lowell. Fcap. Svo. 6s.

"Under the Willows is one of the most admirable bits of idyllic work, short as it is, or perhaps because it is short, that have been done in our gencration."-SATURDAY REview.

Masson (Professor).-ESSAYS, BIOGRAPHICAL AND C.RITICAL. Chiefly on the British Poets. By David Masson, LL.D., Professor of Rhetoric in the University of Edinburgh. Svo. I2s. 6 6 .

"Distinguished by a remarkable pozver of analysis, a clear statement of the actual facts on which speculation is based, and an appropriate beanty of lansuage. These essay's should be popular with serious men." ATHeneuis.

BRITISH NOVELISTS AND THEIR STYLES. Being a Critical Sketch of the History of British Prose Fiction. Crown 8vo. 7 s. $6 d$. "Valuable for its lucid analysis of fundamental principles, its breadth of riew, and sustained animation of style."-SPECTATOR.

MRS. JERNINGHAM'S JOURNAL. Second Edition. Extra fcap. Svo. 3s. 6d. A Poem of the boudoir or domestic class, purporting to be the journal of a newly-married lady.

"One quality in the piece, sufficient of itself to claim a monint's attention, is that it is unique-original, indeed, is not too strong a word--in the manner of its conception and execution."-PALl Mall G.azette.

Mistral (F.).-MirRELLE: a Pastoral Epic of Provence. Trans. lated by H. Crichton. Extra fcap. Svo. $6 s$.

"This is a capital translation of the elegant and richly-coloured pastoral epic poem of M. Mistral which, in 1859, he dedicated in enthusiastic terms to Lamartine. . . . . . It would be hard to overpraise the saretness and pleasing freshness of this chamning epic."-ATHENEUM. 
Myers (Ernest).-THE PURITANS. By Ernest Myers. Extra fcap. 8vo. cloth. 2s. $6 d$.

"It is not too much to call it a really grand poem, stately and disnified, and showing not only a high poetic mind, but also great power over poetic expression." - Literary Churchman.

Myers (F. W. H.).-Poems. By F. W. H. Myers. Extra fcap. 8vo. 4s. $6 d$. Containing "ST. PAUL," "St. JOHN," and other Poems.

"St. Paul stands without a rival as the noblest religious poem which has been written in an age which beyond any other has been prolific in this class of poctry. The sublimest conceptions are expressed in language which for richness, taste, and purity, we have never seen excelled."-JOHN BULL.

Nettleship. - ESSAYS ON ROBERT BROWNING'S Poetry. By John T. Nettleship. Extra fcap. 8vo. 6 s. $6 d$. Noel.-BEATRICE, AND OTHER POEMS. By the Hon. Roden Noel. Fcap. 8vo. 6s.

"Beatrice is in many respects a noble poem; it displays a splendour of landscape painting, a strong definite precision of highly-coloured descrip. tion, which has not often been surpassed."-PALL MALL GazetTe.

Norton.-THE LADY OF LA GARAYE. By the Hon. Mrs. Nortor. With Vignette and Frontispiece. Sixth Edition. Fcap. 8vo. 4s. 6d.

"There is no lack of vigour, no faltering of power, plenty of passion, much bright description, much musical verse. . . . Full of thoughts wellcxpressed, and may be classed among her best works."-Times.

Orwell.-THE BISHOP'S WALK AND THE BISHOP'S

TIMES. Poems on the days of Archbishop Leighton and the

Scottish Covenant. By Orwell. Fcap. 8vo. 5 s.

"Puretaste and faultless precision of language, the fruits of deep thought, insight into human nature, and lively sympathy." -NONCONFORMIST.

Palgrave (Francis T.).-ESSAÝS ON ART. By Francis Turner Palgrave, M.A., late Fellow of Exeter College, Oxford. Extra fcap. 8vo. 6s.

Mulready-Dyce-Holman Hunt-Herbert-Poctry', Prose, and Sen. sationalism in Art-Sculpture in England-The Albert Cross, \&oc. 
SHAKESPEARE'S SONNETS AND SONGS. Edited by F. T. Palgrave. Gem Edition. With Vignette Title by Jeens. $3 s .6 d$. "For minute elegance no volume could possibly excel the "Gem Edition." "-Scotsman.

ORIGINAL HYMNS. By F. T. Palgrave. Third Edition, enlarged, ISmo. Is. $6 d$.

LYRICAL POEMS. By F. T. Palgrave.

$[$ Nearly ready.

Patmore.-Works by Coventry Patmore :-

THE ANGEL IN THE HOUSE.

Book I. The Betrothal; Book II. The Espousals; Book III. Fauthful for Ever. With Tamerton Church Tower. Two vols. Fcap. Svo. I 25 .

* * A New and Cheap Edition in one vol. I8mo., beautifully printed on toned paper, price $2 s .6 d$.

THE VICTORIES OF LOVE. Fcap. 8vo. $4 s .6 d$.

The intrinsic merit of his poem will secure it a permanent place in literature. . . Mr. Patmore has fully earned a place in the catalogue of poets by the finished idealization of domestic life."-SATURDAY REviEw.

\section{Pember (E. H.).-THE TRAGEDY OF LESBOS. A} Dramatic Poem. By E. H Pember. Fcap. 8vo. 4s. $6 d$. Founded upon the story of Sappho.

Richardson.-THE ILIAD OF THE EAST. A Selection of Legends drawn from Valmiki's Sanskrit Poem "The Ramayana." By Frederika Richardson. Crown 8vo. 7s. $6 d$.

"A charming volume which at once enmeshes the reader in its snares." -Athendeum.

Rhoades (James).-POEMS. By James Rhoades. Fcap. Svo. 4 s. $6 d$.

Poems And Sonnets. Contents :-Ode to Harmony; To the Spirit of Unrest; Ode to Winter; The Tunnel; To the Spirit of Beauty; Song of a Leaf; By the Rotha; An Old Orchard; Love and Rest; The Flowers Surprised; On the Death of Artemus Ward; The Two Paths; The Ballad of Little Maisie; Sonnets. 
Rossetti.-Works by CHRIstina ROSSET'I :-

GOBLIN MARKET, AND OTHER POEMS. With two Designs by D. G. Rossetti. Second Edition. Fcap. Svo. $5^{\text {s. }}$

"She handles her little marvel with that rare poetic discrimination which neither exhausts it of its simple wonders by pushing symbolism too far, nor keeps those wonders in the merely fabulous and capricious stage. In fact she has produced a true children's poem, which is far more delightful to the mature than to children, though it would be delightful to all." SPECTATOR.

THE PRINCE'S PROGRESS, AND OTHER POEMS. With two Designs by D. G. Rossetti. Fcap. 8vo. $6 s$.

"Miss Rossetti's poems are of the kind which recails Shelley's definition of Poetry as the record of the best and happiest moments of the best and happiest minds. . . . They are like the piping of a bird on the spray in the sunshine, or the quaint singing with which a child amuses itself when it forgets that anybody is listening." -SATURDAY REVIEW.

Rossetti (W. M.).-DANTE'S Hell. See "Dante."

FINE ART, chiefly Contemporary. By Willian M. Rossetti. Crown Svo. Ios. $6 d$.

This volume consists of Criticism on Contemporary Art, reprinted from Fraser, The Saturday Review, The Pall Mall Gazette, and other publications.

Roby.-STORY OF A HOUSEHOLD, AND OTHER POEMS. By Mary K. Roby. Fcap. 8vo. 5 s.

Seeley (Professor). - LECTURES AND ESSAIS. By J. R. Seeley, M.A. Professor of Modern History in the University of Cambridge. 8vo. Ios. $6 d$.

Contents :-Roman Imperialism: I. The Great Roman Revolution; 2. The Proximate cause of the Fall of the Roman Empire; 3. The Later Empire.-Milton's Political Opinions-Milton's Postry-Elementary Princifles in Art-Liberal Education in Universities-English in Schools-The Church as a Teacher of Morality-The Teaching of Politics: an Inaugural Lecture delivered at Cambridse. 
Shairp (Principal).-KILMAHOE, a IHighland Pastoral, with other Poems. By John Campbell Shairp. Fiap. 8vo. $5^{s .}$

"Kilmahoe is a Highland Pastoral, redolent of the warm soft air of the Western Lochs and Moors, sketched out with remarkable grace and picturesqueness."-SATURDAY REVIEW.

Smith.-Works by Alexander Sirth :-

A LIFE DRAMA, AND OTHER POEMS. Fcap. 8vo. $2 s .6 d$. CITY POEMS. Fap. 8vo. 5s.

EUIVIN OF DEIRA. Second Edition. Fcap. 8vo. 5 s.

"A poem which is marked by the strength, sustained sivectness, and compact texture of real life."-NorTh BRITISH Review.

Smith.-POEmS. By Catherine Barnard Smith. Fcap. Svo. 5s.

" Wealthy in feeling, meaning, finish, and grace; not without passion, which is suppressed, but the keener for that."-ATHEN\&UM.

Smith (Rev. WValter).-HYMNS OF CHRIST AND TIE CHRistian Life. By the Rev. Walter C. Sirth, M.A. Fcap. Svo. $6 s$.

"These are among the sweetest sacred poenns we have read for a long time. With no profuse imagery, expressing a range of feeling and extression by no means uncommon, they are true and elevated, and them pathos is profound and simple."-NONCONFORMIST.

Stratford de Redcliffe (Viscount).-SHADOWS OF THE PAST, in Verse. By Viscount Stratford dE RedCliffe. Crown 8vo. Ios. $6 d$.

"The vigorous words of one who has acted vigorously. They coinbine the firvour of politicians and poet."-GUARDIAN. 
Trench.-Works by R. Chenevix Trench, D.D., Archbishop of Dublin. See also Sections "Philosophy," “Theology," \&c.

POEMS. Collected and arranged anew. Fcap. 8vo. 7s. $6 d$.

ELEGIAC POEMS. Third Edition. Fcap. 8vo. 2s. $6 d$.

CALDERON'S LIFE'S A DREAM: The Great Theatre of the World. With an Essay on his Life and Genius. Fcap. Svo. 4s. $6 d$.

HOUSEHOLD BOOK OF ENGLISH POETRY. Selected and arranged, with Notes, by R. C. TRench, D.D., Archbishop of Dublin. Second Edition. Extra fcap. 8vo. 5s. $6 d$.

This volume is called a "Household Book," by this name implying that it is a book for all-that there is nothing in it to prevent it from being confidently plact in the hands of every. member of the household. Specimens of all classes of poetry are siven, including selections from living authors. The Editor has aimed to produce a book "which the emigrant, finding room for little not absolutely necessary, might yei fina room for in his trunk, and the traveller in his knapsack, and that on some narrow shelves where there are few books this might be one."

" The Archbishop has conferred in this delightful volume an important gift on the whole English-speaking population of the world."-PALL Mall Gazette.

SACRED LATIN POETRY, Chiefly Lyrical. Selected and arranged for Use. Second Edition, Corrected and Improved. Fcap. Svo. $7 s$.

"The aim of the present volume is to offer to members of our Engtish Church a collection of the best sacred Latin poetry, such as thev shall be able entirely and heartily to accept and approve-a collection, that 2 s, in which they shall not be evermore liable to be offended, and to have the current of their sympathies checked, by coming upon that which, however beautiful as poetry, out of hisher respects they must reject and condemn-in which, too, they shall not jear that snares are bing laid for them, to entangle them unawares in admiration for aught which is inconsistent with their faith and fealty to their own spiritual mother."-PREFACE.

Turner.-SOnnets. By the Rev. Charles Tennyson Turver. Dedicated to his brother, the Poet Laureate. Fcap. Evo. 4 s. $6 d$. 
"The Sonnets are dedicated to Mr. Tennyson bv his brother, and have, independently of their merits, an interest of association. Thev both love to write in simple expressive Saxon; both love to touch thir imagery in epithets rather than in formal similes; both have a delicate perception of rhythmical movement, and thus Mr. Turner has occasional lines which, for phrase and music, might be ascribed to his brother. . . He knows the haunts of the wild rose, the shady nooks where light quivers through the leaves, the ruralities, in short, of the land of imagination."-ATHENEUM.

SMALL TABLEAUX. Fcap. 8vo. 4 s. $6 d$.

"These brief poems have not only a pecuiiar kind of interest for the student of English poetry, but are intrinsically delightful, and will reward a careful and frequent perusal. Full of naïvete, piety, love, and knowledge of natural objects, and each expressing a single and generally a simple subject by means of munte and original pictorial touches, these sonnets have a place of their own."-PALL MALl Gazette.

\section{Vittoria Colonna.-LIFE AND POEMS. By Mrs. Henry}

Roscoe. Crown Svo. 9s.

The life of Vittoria Colonna, the cilebrated Marchesa di Pescara, has recived but cursory notice from any English writer, though in every history of Italy her name is mentioned with great honour among the pocts of the sixteenth century. "In three hundred and fifty years," say's her biographer, Visconti, "there has been no other Italian lady who can be comparal to her."

"It is written with good taste, with quick and intelligent sympathy, occasionally with a real freshness and charm of style."-PALL MALL GazetTe.

Webster.-Works by Augusta Webster:-

"If Mrs. Webster only remains true to herself, she will assuredly tuke a higher rank as a poet than any woman has yet done."WESTMINSTER Review.

DRAMATIC STUDIES. Extra fcap. 8vo. 5 s.

"A volume as strongly marked by" perfect taste as by" poetic power." NONCDNFORMIST.

PROMETHEUS BOUND OF ASCHYLUS. Literally translated into English Verse. Extra fcap. Svo. $3 s .6 d$.

"Closeness and simplicity combined with literary skill."-ATHENÆUM. 
“Mrs. Webster's 'Dramatic Siudies' and 'Translation of Prometheus' have won for her an honourable place among our female poets. She writes with remarkable vigour and dramatic realization, and bids fair to be the most successful clamant of Mrs. Browning's mantle."-BRITISH QUARTERLy Review.

MEDEA OF EURIPIDES. Literally translated into English Verse.

Extra fcap. Svo. 3 s. 6d.

"Mrs. Webster's translation surpasses our utmost expectations. It is a photograph of the original without any of that harshness which so often accompanies a photograph."-. WESTMINSTER REVIEw.

A IVOMAN SOLD, AND OTHER POEMS. Crown Svo. 7s. $6 d$.

"Mrs. Webster has showen us that she is able to draze admirably from the life; that she can observe with subtlety, and render her observations with delicacy; that she can impersonate complex conceptions, and venture into which few living writers can follow her."-GUARDIAN.

PORTRAITS. Second Edition. Extra fcap. Svo. 3s. $6 d$.

"Mrs. Webster's poems exhibit simplicity and tenderness. . . her taste is perfect . . . This simplicity' us combined with a subtlety of thought, feeling, and observation which demand that attention which only real lovers of poetry are apt to bestow. . . . If she onlv remains true to herself she will most assuredly take a higher rank as a poet than any woman has yet done."-Westminster Review.

"With this volume before us it would be hard to deny her the proud position of the first living English poetess." -ExAmINER.

\section{Woodward (B. B., F.S.A.).-SPECIMENS OF THE} DRA IVINGS OF TEN MASTERS, from the Royal Collection at Windsor Castle. With Descriptive Text by the late B. B. WooDWARD, B.A., F.S.A., Librarian to the Queen, and Keeper of Prints and Drawings. Illustrated by Twenty Autotypes by EDWARDS and KIDD. In 4to. handsomely bound, price $25 \mathrm{~s}$.

This volume contains facsimiles of the works of Michael Angelo, Perugino, Raphael, Fulio Romano, Leonardo da Vinci, Giorgione, Paul Veronese, Poussin, Albert Dïrer, Holbein, executed by the Autotype (Carbon) process, which may be accepted as, so far, perfect representations of the originals. In most cases some reduction in size was necessary, and then the dimensions of the drawing itself have been given. Brief biographical memoranda of the life of each master are inserted, solely to prevent the need of reference to other works. 
Wooiner.-MY BEAUTIFUL LADY. By Thomas Woolner. With a Vignette by Arthur Hughes. Third Edition. Fcap. Svo. 5 s.

"It is clearly the product of no idle hour, but a highly-conceived and faithfully-executed task, self-imposed, and prompted by that inward yearning to utter great thoughts, and a wealth of passionate feeling which is poetic genizus. No man can read this poem without being struck by the fitness and finish of the workmanship, so to speak, as well as by the chastened and unpretending loftiness of thought which bervades the whole." Globe.

WORDS FROM THE POETS. Selected by the Editor of "Rays of Sunlight." With a Vignette and Frontispiece. I8mo. limp., I $s$.

Wyatt (Sir M. Digby).--FINE ART : a Sketch of its History, Theory, Practice, and application to Industry. A course of Lectures delivered before the University of Cambridge. By Sir M. Digby Wyatt, M. A. Slade Professor of Fine Art. 8vo. IOs. $6 d$. 


\section{THE GLOBE LIBRARY.}

Beautifully printed on toned paper and bound in cloth elegant, price 4s. $6 d$. each. In plain cloth, 3s. $6 d$. Also kept in various styles of Morocco and Calf bindings.

THE SATURDAY REVIEW says-"The Globe Editions are' admirable for their scholarly editing, their typographical excellence, their compendious form, and their cheapness."

Under the title GLOBE EDITIONS, the Publishers are issuing a uniform Series of Standard English Authors, carefully edited, clearly and elegantly printed on toned paper, strongly bound, and at a small cost. The names of the Editors whom they have been fortunate enough to secure constitute an indisputable guarantee as to the character of the Series. The greatest care has been taken to ensure accuracy of text; adequate notes, elucidating historical, literary, and philological points, have been supplied; and, to the older Authors, glossaries are appended. The series is especially adapted to Students of our national Literature; while the small price places good editions of certain books, hitherto popularly inaccessible, within the reach of all. The Saturday Reviez says: "The Globe Editions of our English Poets are admirable for their scholarly editing, their typographical excellence, their compendious form, and their cheapness." 
Shakespeare.-THE COMPLETE WORKS OF WILLIAM SHAKESPEARE. Edited by W. G. Clark and W. Aldis WRIGHT.

"A marvel of beauty, cheapness, and compactness. The whole worksplays, poems, and sonnets-are contained in one small volume: yet the page is perfectly clear and readable. . . . For the busy man, above all for the working student, the Globe Edition is the best of all existing Shakespeare books."-ATHEN\&UM.

Morte D'Arthur.-SIR THOMAS MALORY'S BOOK OF KING ARTHUR AND OF HIS NOBLE KNIGHTS OF THE ROUND TABLE. The Edition of CAXTON, revised for Modern Use. With an Introduction by Sir Edward Strachey, Bart.

"It is with the most perfect confidence that we recommend this edition of the old romance to every c?.ass of readers."-PALL MALL GAZETTE.

Scott.-THE POETICAL WORKS OF SIR WALTER SCOTT. With Biographical Essay by F. T. Palgrave. New Edition.

"As a popular edition it leaves nothing to be desired. The want of such an one has long been felt, combining real excellence with cheapness." -Spectator.

Burns.-THE POETICAL WORKS AND LETTERS OF ROBERT BURNS. Edited, with Life, by Alexander Smith. New Edition.

"The works of the bard have never been offered in such a complete form in a single volume."-GLASGOW DAILY HERALD.

"Admirable in all respects."-SPECTATOR.

\section{Robinson Crusoe.-THE ADVENTURES OF ROBINSON}

CRUSOE. By DEFoe. Edited, from the Original Edition, by J. IV. Clark, M.A., Fellow of Trinity College, Cambridge. With Introduction by HeNRY KingsLey.

"The Globe Edition of Robinson Crusoe is a book to have and to keep. It is printed after the original editions, with the quaint old spelling, and" 
is published in admirable style as regards type, paper, and binding. A well-written and genial biographical introduction, by Mr. Henry Kingsley, is likewise an attractive feature of this edition."-MORNING STAR.

\section{Goldsmith.-GOLDSMITH'S MISCELLANEOUS WORKS.}

With Biographical Essay by Professor Masson.

This edition includes the whole of Goldsmith's Miscellaneous Worksthe Vicar of Wakefield, Plays, Poems, \& c. Of the memoir the Scotsman nezuspaper worites: "Such an admirable compendium of the facts of Goldsmith's life, and so careful and minute a delineation of the mixed traits of his peculiar character, as to be a very model of a literary biography."

Pope.-THE POETICAL WORKS OF ALEXANDER POPE.

Edited, with Memoir and Notes, by Professor WARD.

"The book is handsome and handy. . . . The notes are many", and the matter of them is rich in interest."-ATHENÆUM.

\section{Spenser. - THE COMPLETE IVORKS OF EDMUND}

SPENSER. Edited from the Original Editions and Manuscripts, by R. MorRis, Member of the Council of the Philological Society. With a Memoir by J. W. Hales, M.A., late Fellow of Christ's College, Cambridge, Member of the Council of the Philological Society.

"A complete and clearly, brinted edition of the whole works of Spenser, carefully collatea with the originals, wnth copions glossary, worthy-and higher praise it necds not-of the beautiful Globe Series. The work is edited with all the care so noble a poet deserves." -DAILY News.

Dryden.- THE POETICAL WORKS OF JOHN DRYDEN. Edited, with a Revised Text, Memoir, and Notes, by W. D. Christie.

"The work of the Editor has been done with much fulness, care, and knowledge; a vell-written and exhaustive memoir is prefixed, and the notes and text together have been so well treated as to make the volume a fitting companion for those which have preceded it-whach is saying not a little."-Daily Telegraph. 
Cowper.-THE POETICAL WORKS OF IVILLIAM COW.

PER. Edited, with Biographical Introduction and Notes, by W. BENHAM.

"Mr. Benham's edition of Cowper is one of permanent value. The biographical introduction is excellent, full of information, singularly neat and readable, and modest-too modest, indeed-in its comments. The notes seem concise and accurate, and the editor has been able to discover and introduce some hitherto unprinted matter."-SATURDAY REVIEW.

\section{Virgil.-THE WORKS OF VIRGIL RENDERED INTO}

ENGLISH PROSE, with Introductions, Running Analysis, and an Index, by James Lonsdale, M.A., and Samuel Lee, M.A. Globe 8 vo.

The preface of this new volume informs us that "the original has been faithfully rendered, and paraphrase altogether avoided. At the same time, the translators have endeavoured to adapt the book to the use of the English reader. Some amount of rhythm in the structure of the sentence has been scnerally maintained; and, when in the Latin the sound of the words is an echo to the sense (as so frequently happens in Virgil), an attempt has been made to produce the same result in English."

The general introduction gives us whatwer is known of the poet's life, an estimate of his genius, an account of the princital editions and translations of his works, and a brief view of the influence he has had on modern poets; special introductory essays are prefixed to the Eclogues, Georgics, and Eneid. The text is divided into sections, each of which is headed by a concise analysis of the subject; the index contains references to all the characters and events of any importance.

** Other Standard Works are in the Press.

${ }_{*}^{*}$ The Volumes of this Series may be had in a variety of morocco and calf bindings at very moderate prices.

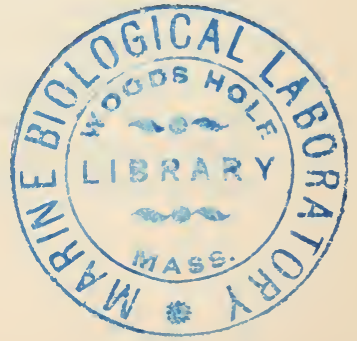




\section{MACMILLAN'S}

\section{GOLDEN TREASURY SERIES.}

Uniformly printed in $\mathrm{r} 8 \mathrm{mo}$., with Vignette Titles by SiR Noel Paton, T. Woolner, IV. Holman Hunt, J. E. Millais, Arthur Hughes, \&c. Engraved on Steel by Jeens. Bound in extra cloth, 45 . $6 d$. each volume. Also kept in morocco and calf bindings.

"Messrs. Macmillan have, in their Golden Treasury Series especially, provided editions of standard works, volumes of selected poetry, and original compositions, which entitle this series to be called classical. Nothing can be better than the literary execution, nothing more elegant than the material workmanship."-BRITISH QUARTERLY Review.

THE GOLDEN TREASURY OF THE BEST SONGS AND LYRICAL POEMS IN THE ENGLISH LANGUAGE. Selected and arranged, with Nates, by FrancIS TURNer Palgrave.

"This delightful little volume, the Golden Treasury, which contains many of the best original lyrical pieces and songs in our language, grouped? with care and skill, so as to illustrate each other like the pictures in a well-arranged gallery."-QUARTERLY REVIEW.

THE CHILDREN'S GARLAND FROM THE BEST POETS Selected and arranged by Coventry PATMORE.

"It includes specimens of all the great masters in the art of poetry, selected with the matured judgment of a man concentrated on obtaining insight into the feelings and tastes of childhood, and desirous to awaken its finest impulses, to cultivate its keenest sensibilities."-MORNING POST. 
THE BOOK OF PRAISE. From the Best English Hymn Writers. Selected and arranged by Sir Roundell Palmer. A New and Eniarged Edition.

"All previous compilations of this kind must undeniably for the present give place to the Book of Praise. . . The selection has been made thronghont with sunnd judgment and critical taste. The pains involved in this compilation must have been immense, embracing, as it does, every writer of note in this special province of English literature, and ranging over the most widely divergent tracks of religious thought."-SATURDAY Review.

THE FAIRY BOOK; the Best Popular Fairy Stories. Selected and rendered anew by the Author of "John Halifax, Gentleman."

"A delightful selection, in a delightful external form; full of the physical splendour and vast opnlence of proper fairy tales."-SPECTATOR.

THE BALLAD BOOK. A Selection of the Choicest British Ballads. Edited by William Allingham.

" His taste as a judge of old poetry will be found, by all acquainted with the various readings of old English ballads, true enough to justify his undertaking so critical a task."-SATURDAY REviEW.

THE JEST BOOK. The Choicest Anecdotes and Sayings. Selected and arranged by MARK LEMON.

"The fullest and best jest book that has yet appeared."-SATURDAY REVIEW.

BACON'S ESSAYS AND COLOURS OF GOOD AND EVIL. With Notes and Glossarial Index. By IV. Aldis IVRIght, M.A.

"The beautiful little edition of Bacon's Essays, now before us, does credit to the taste and scholarship of Mr. Aldis Wright. . . . It puts the reader in possession of all the essential literary facts and chronolony necessary for reading the Essays in connexion with Bacon's life and times."-SPECTATOR.

"By far the most complete as well as the most elegant edition "ve possess."-Westminster Review. 
THE PILGRIM'S PROGRESS from this World to that which is to come. By John Bunyan.

"A beautiful and scholarly reprint."-SPECTATOR.

THE SUNDAY BOOK OF POETRY FOR THE YOUNG.

Selected and arranged by C. F. Alexander.

"A well-selected volume of Sacred Poetry." - Spectator.

A BOOK OF GOLDEN DEEDS of all Times and all Countries. Gathered and narrated anew. By the Author of "THE HEIR OF REDCLYFFE."

". . . To the young, for whom it is especially intended, as a most interesting collection of thrilling tales well told; and to their elders, as a useful handbook of reference, and a pleasant one to take up when their wish is to while away a weary half-hour. We.have seen no prettier sift-book for a long time."-ATHEN瓜UN.

THE POETICAL WORKS OF ROBERT BURNS. Edited, with Biographical Memoir, Notes and Glossary, by Alexander Smith. Two Vols.

"Beyond all question this is the most beaniful edition of Burns yet out."-Eninburgh Daily Review.

THE ADVENTURES OF ROBINSON CRUSOE. Edited from the Original Edition by J. IV. Clark, M.A., Fellow of Trinity College, Cambridge.

"Mutilated and modified editions of this English classic are so much the rule, that a cheap and pretty copy of it, rigidly exact to the origina?, will be a prize to many book-buyers."-EXAMINER.

THE REPUBlic OF PLATO. Translated into English, wilh

Notes by J. Ll. Davies, M.A. and D. J. Vaughan, M.A.

"A dainty and cheap little edition."-EXAMINER.

THE SONG BOOK. Words and Tunes from the best Poets and Musicians. Selected and arranged by John Hullah, Professor of Vocal Music in King's College, London.

"A choice collection of the sterling songs of Englana, Scotland, and Ireland, with the music of each prefixed to the words. How much true wholesome pleasure such a book can ai,fuse, and will diffuse, zue trust, through many thousund families."-EXANINER. 
LA LYRE FRANCAISE. Selected and arranged, with Notes, by Gustave Masson, French Master in Harrow School. A selection of the best French songs and lyrical pieces.

TOM BROWN'S SCHOOL DAYS. By an OLD Boy.

"A perfect gem of a book. The best and most healthy book about boys for oj's that ever was written." - ILL USTRATED TiMES.

A BOOK OF WORTHIES. Gathered from the Old Histories and written anew by the Author of "The Heir of ReDClyffe." With Vignette.

"An admirable addition to an admirable series." - WestMINSTER REview.

A BOOK OF GOlden thoughts. By Henry AtTwell, Knight of the Order of the Oak Crown.

"Mr. Attwell has produced a book of rare value . . . . Happily it is smail enough to be carried about in the pocket, and of such a companion it would be difficult to weary." - PALL MALL GazeTtE. 
LONDON :

R. CLAY, SONS, AND TAYLOR, PRINTERS, BREAD STREET HILL. 



